\title{
Risk of Infections of Biological Therapies with Accent on Inflammatory Bowel Disease
}

\author{
Radu M. Nanau ${ }^{1,2}$, Lawrence B. Cohen ${ }^{3,4}$ and Manuela G. Neuman ${ }^{1,2}$ \\ ${ }^{1}$ Department of Pharmacology and Toxicology, Faculty of Medicine, University of Toronto, and ${ }^{2}$ In Vitro Drug Safety and \\ Biotechnology, ${ }^{3}$ Division of Gastroenterology, Sunnybrook Health Science Centre, and ${ }^{4}$ Departments of Internal \\ Medicine, University of Toronto, Toronto, Ontario, Canada.
}

Received, August 1, 2014; Revised, October 2, 2014; Accepted, October 24, 2014; Published, October 26, 2014.

\begin{abstract}
Background: Biological therapies using anti-tumor necrosis factor (TNF)- $\alpha$ agents have an important impact in the treatment of inflammatory bowel disease, rheumatoid arthritis, psoriasis, and other inflammatory conditions. However, a significant number of patients lose their response to these medications over time. Clinical trials have demonstrated that antibodies against anti-TNF agents may impact treatment response and increase the risk of infusion reactions. Of concern is also the possibility of developing adverse events induced by anti-TNF agents. The purpose of the present systematic review is to describe the current knowledge on the risk of infections associated with anti-TNF agents antagonists, as well as integrin antagonists. We also intend to describe case reports of these adverse events in inflammatory bowel disease patients. Methods: Currently approved anti-TNF biologicals in IBD include the monoclonal antibodies infliximab, adalimumab, certolizumab pegol and golimumab. Integrin antagonists include natalizumab, etrolizumab and vedolizumab. Results: The most frequently-reported adverse events of these biologicals were infections, and these are described in detail in this study. Discussion: Most adverse events are due to the failure of host immunological control, which involves de novo infection, or reactivation of latent bacterial or viral infection, often with a different expression of disease. Conclusion: Risk assessment in individuals undergoing treatment with biologicals represents a step towards achieving treatment personalization to identify those patients that will safely benefit from this therapeutic approach. Patients and physicians must be alert for anti-TNF agents and anti-integrin medication as potential causes of drug-induced infections and monitor the therapies. Personalizing therapeutic vigilance promises to optimize benefits while minimizing infections.
\end{abstract}

This article is open to POST-PUBLICATION REVIEW. Registered readers (see "For Readers") may comment by clicking on ABSTRACT on the issue's contents page.

\section{INTRODUCTION}

The intermittent destructive inflammation of the intestinal tract describes a medical condition known as inflammatory bowel disease (IBD). The two main entities of IBD are Crohn's disease (CD), histologically characterized by transmural inflammation with asymmetrical and discontinuous granulomas, and ulcerative colitis (UC), which can be identified through inflammation limited to the intestinal mucosa. A number of factors increase the risk of IBD, including genetic predisposition, and environmental and epigenetic factors. IBD was initially managed with agents such as 5aminosalicylate formulations such as sulphasalazine, mesalamine and olsalazine, oral steroids such as prednisolone, methylprednisolone and budesonide, and immunomodulating drugs such as azathioprine, 6-mercaptopurine, cyclosporin and methotrexate $(1,2)$.

The development and pathogenesis of IBD is strongly mediated by inflammation, with tumor necrosis factor (TNF)- $\alpha$, interferon (IFN) and interleukin (IL)-12/23 playing key roles $(3,4)$. As such, biological treatment with TNF- $\alpha$ inhibitors represents an important therapeutic strategy to block the pro-inflammatory cascade associated with this cytokine, thus re-establishing the balance between the pro- and anti-inflammatory messages

Corresponding Author: Manuela Neuman, $\mathrm{PhD}$, Department of Pharmacology and Toxicology, In Vitro Drug Safety and Biotechnology, Banting Institute, 100 College Street, Lab 217, Toronto, Ontario, Canada; manuela.neuman@utoronto.ca 
in the intestinal mucosa (5).

TNF- $\alpha$ is a $\mathrm{T}$ helper 1 pro-inflammatory cytokine that plays a key role in the integrated host defence system against infectious diseases. This cytokine is physiologically antagonized by TNFbinding proteins (6). The four anti-TNF agents currently approved in IBD are the monoclonal antibodies infliximab (IFX; Remicade), adalimumab (ADM; Humira), certolizumab pegol (CZP; Cimzia) and golimumab (GLM; Simponi). Due to its lack of efficacy in active CD, the antiTNF fusion protein etanercept (Enbrel) is not used (7). In addition, integrin antagonists such as natalizumab (NTZ; Tysabri), vedolizumab (VDZ; Entyvio) and etrolizumab (ETZ, Genentech Inc.) have also been used.

As immunomodulatory therapies, anti-TNF agents lower the ability of the immune system to ward off infections. Serious infections are the primary adverse events associated with biological therapies (8). These include tuberculosis (TB) and infections caused by other bacteria, fungi and viruses that have spread throughout the body, especially among older individuals (9-12). As IBD patients account for one third of biologicals users (13), it is important to understand the adverse events associated with their use in this population. Moreover, this knowledge will impact on the personalized medication and ultimately in patients health.

Integrins are involved in the adhesion of leukocytes to the vascular endothelium, and their migration from the circulation into the inflamed tissue. Integrins also contribute to the activation of immune cells through molecular signalling (14). These glycoproteins bind matrix proteins in the intestinal mucosa, as well as ligands such as intercellular adhesion molecules and vascular cell adhesion molecule-1 (15). Their role in the inflammation and repair of the intestinal mucosa was described by Jones et al. (16) and reviewed by Gosh et al. (17).

The incidence of serious infections was $2.2 \%$ in a large IBD sample treated with anti-TNF agents over an 11 years period in Australia and New Zealand (18). Cases of active TB were prevented by administering prophylaxis prior to initiating antiTNF treatment in individuals with latent TB (18). Non-TB opportunistic infections identified in the French research axed on tolerance of biotherapies registry and in the Australian and New Zealand cohort include bacterial infections such as non-TB mycobacteriosis (NTM), listeriosis, nocardiosis, salmonellosis and staphylococcosis, fungal infections such as pneumocystosis, aspergillosis and cryptococcosis, and viral infections such as cytomegalovirus (CMV), varicella zoster virus (VZV) and herpes simplex virus (HSV) $(18,19)$. IFX treatment [odds ratio (OR) 10.9, 95\% confidence interval (CI) 2.9-40.8, $\mathrm{p}=0.0004]$ and ADM treatment (OR 6.1, 95\% CI 1.5-25.5, $\mathrm{p}=0.013$ ) were risk factors for opportunistic infections in a case-control analysis of patients treated with anti-TNF agents (19). Concomitant immunosuppressant treatment, particularly steroids, is an additional risk factor for opportunistic infections (19-21). In a large review, the highest risk of opportunistic infections was among CD patients undergoing anti-TNF treatment with concomitant steroids compared to individuals without CD (OR 14.09, 95\% CI 2.84-69.81), showing that a diagnosis of $\mathrm{CD}$, anti-TNF treatment and especially immunosuppressant combinations are risk factors for opportunistic infections (20).

The most common infections associated with IFX affect the respiratory (including sinusitis, pharyngitis and bronchitis) and the urinary tracts. Serious infections including $\mathrm{TB}$, pneumonia, cellulitis, abscess, skin ulceration and sepsis are rare in IBD patients undergoing anti-TNF treatment (9). Upper respiratory tract infections were also the most common infectious adverse events in pediatric IBD patients treated with IFX, along with lower respiratory tract infections, skin and soft tissue infections, gastrointestinal infections, musculoskeletal infections, genitourinary infections, and well as sepsis/bacteremia, meningitis, histoplasmosis and Mycobacterium infections (including both pulmonary and extrapulmonary TB) (22-25). The most common opportunistic infections in children and adolescents are caused by viruses, including primary VZV, herpes zoster, HSV and Epstein-Barr virus (EBV) (25). As these infections are largely limited to members of the herpesvirus family, which are generally acquired during childhood, it is unclear whether their acquisition relates to the underlying disease or to the anti-TNF treatment. Rare fungal and bacterial infections, including pulmonary $\mathrm{TB}$, are likely to be related to intrinsic factors and to immunosuppression (25). The overall rates of infections were similar between UC and CD patients $(22,24)$. 
The rates of serious infections are generally similar between IFX regimens and placebo (26). A large review found comparable rates of developing opportunistic infections between $\mathrm{CD}$ patients receiving anti-TNF treatment alone and $\mathrm{CD}$ patients not receiving any treatment (20). There were no significant differences in the rates of serious infections requiring treatment modifications between patients who received one or multiple IFX infusions (27). The incidence of opportunistic infections was highest during the first year of IFX treatment in a retrospective cohort. Previous treatment with $\geq 2$ immunosuppressive agents was the main risk for developing opportunistic infections while receiving IFX. Severe infection rates are higher in elderly IBD patients ( $\geq 65$ years) treated with IFX or ADM compared to elderly IBD patients ( $\geq 65$ years) treated with non-biologicals or younger IBD patients ( $<65$ years) treated with IFX or ADM (28).

The most serious adverse events of ADM are also infections, including new onset and reactivation of $\mathrm{TB}$, with both pulmonary and extrapulmonary manifestations, as well as other previous infections with bacteria, invasive fungi, viruses, parasites (10). The rates of infection were similar between ADM and placebo patients, regardless of presence of immunosuppressants (29). A separate trial found infections to be more common in ADM patients during the maintenance phase compared to the induction phase (30).

Less information is available for CZP and GLM. Acquiring or worsening pre-existing infections is the main type of adverse event associated with CZP (11). The rates of adverse events, including infections, were similar between CZP and placebo in CD patients, both in the short term and in the long term $(31,32)$.

GLM is similarly associated with serious infections, the most notable of which are TB and hepatitis B virus (HBV) reactivation, but also sepsis, pneumonia, cellulitis, abscess and invasive fungal infections $(12,33,34)$.

Serious infections were reported in $3.2 \%$ of patients with moderate to severe UC receiving GLM (34). The rates of infection were similar between GLM and placebo in the short term (33). Despite low incidences of infections in either group, GLM may be associated with a higher risk in the long term (34). The incidence of TB through week 54 was similar between GLM and placebo (34). The rates of infections were similar between GLM and placebo in rheumatoid arthritis (RA) and psoriasis cohort (35-37).

Due to the increased risk of serious infections associated with anti-TNF treatment (9-12), adherence to several guidelines can help lead to a safer anti-TNF treatment course in gastroenterology, rheumatology and dermatology patients (38). Screening for active or latent TB is strongly recommended. On the other hand, screening for CMV or EBV is not necessary, nor is it necessary for hepatitis $\mathrm{C}$ virus (HCV). Vaccination against VZV and annual influenza vaccination are recommended. Vaccination against HBV is also recommended, although its efficiency in preventing $\mathrm{HBV}$ infection remains debatable in patients undergoing anti-TNF treatment. Vaccination against human papilloma virus is recommended in the general young female population, with an unclear relationship between anti-TNF treatment and the efficacy of vaccination. Anti-TNF treatment is generally not considered to increase human immunodeficiency virus (HIV) viremia (38).

The present systematic review aims to identify and describe infectious adverse events associated with the use of anti-TNF agents and integrin antagonists, with a particular focus on patients afflicted with IBD. The various microorganisms responsible for the infections were identified in clinical trials and cohort studies, while case reports described in detail the clinical manifestations and disease course of these infections.

\section{MATERIALS AND METHODS}

Placebo-controlled trials assessing the efficacy and safety of IFX, ADM, CZP and GLM in IBD patients were identified through a PubMed search using combination of terms with the name of the drug ("infliximab," "adalimumab," "certolizumab pegol," "golimumab," "natalizumab", "vedolizumab" and "etrolizumab"), the name of the disease ("Crohn's disease," "ulcerative colitis" or "inflammatory bowel disease"), and the term "clinical trial." Recent open-label trials (2010-2014) were also retrieved using similar search criteria. The risk of infection was further assessed in other recent cohort studies, especially ones involving IBD patients, using the name of the drug and one of "tuberculosis," "Mycobacterium," "listeriosis," 
"Listeria," "legionellosis," "Legionella," "staphylococcemia," "Staphylococcus ," "salmonellosis," "Salmonella," "nocardiosis," "Nocardia," "Pseudomonas," "pneumocystosis," "Pneumocystis," "histoplasmosis," "Histoplasma," "aspergillosis," "Aspergillus," "cryptococcosis," "Cryptococcus," "candidiasis," "Candida," "actinomycosis," "Actinomyces," "blastomycosis," "Blastomyces," "coccidioidosis," "Coccidioides," "hepatitis B virus," "hepatitis C virus," "herpesvirus," "cytomegalivirus," "varicella zoster virus," "herpes simplex virus," "Epstein-Barr virus," "John Cunningham virus" and "human immunodeficiency virus." Case reports describing these infections in IBD patients were reviewed regardless of when they were published. An additional Google Scholar search was performed. Nevertheless, there are interpretation limitations since data collection by various centers may introduce great variability. Moreover, there is patient heterogeneity depending on the criteria of the study, as well as the variants taken into account in each study. We have to acknowledge that this is a systematic review of the literature, but no metaanalysis of the data was carried out.

\section{RESULTS AND DISCUSSIONS}

\section{BACTERIAL INFECTIONS Tuberculosis}

$\mathrm{TB}$ is an infectious disease caused by Mycobacterium tuberculosis. De novo TB infections or reactivation of latent TB infections are the adverse events of most concern in patients with inflammatory diseases undergoing anti-TNF treatment. In the French research axed on tolerance of biotherapies registry, the rate of TB was higher among anti-TNF patients than among the general population (standardized incidence ratio (SIR) 12.2, 95\% CI 9.7-15.5 for anti-TNF treatment, SIR 18.6, 95\% CI 13.4-25.8 for IFX and SIR 29.3 95\% CI 20.2-42.4 for ADM) (39). Similar findings are reported elsewhere $(40,41)$. The incidence of TB was $3.3 \%$ among patients with inflammatory diseases in a Portuguese population (41). TB occurs predominantly in the first 6 months of treatment with anti-TNF agents (42).

The risk of serious infections differs between anti-TNF biologicals according to the drug class. The rates of $\mathrm{TB}$ are higher in patients receiving monoclonal antibodies (IFX and ADM). An in vitro study using peripheral blood mononuclear cells stimulated with $M$. tuberculosis antigen showed that IFX almost completely abolishes TNF- $\alpha$ release, while also reducing IFN- $\gamma$ release. This has important implications as TNF- $\alpha$ and IFN- $\gamma$ contribute to the formation of granulomas and the containment of bacteria (43). Significantly, antiTNF monoclonal antibodies suppress IFN- $\gamma$ production by IL-10-independent mechanisms. IFX and ADM interfere with immune functions mediated by TNF- $\alpha$, leading to inadequate maturation and acidification of mycobacteriacontaining phagosomes, as well as decreased autophagy and apoptosis of mycobacteriacontaining macrophages. This further interferes with mycobacteria antigen presentation and innate immunity. As such, monoclonal antibodies suppress antigen-induced IFN- $\gamma$ production. IFX and ADM thus have concentration-dependent effects on the control of intracellular growth of $M$. tuberculosis (44-48).

IFX was also linked with complement-mediated lysis of cells expressing transmembrane TNF- $\alpha$, such as macrophages and monocytes. Mechanistically, the loss of macrophages and monocytes leads to a shift towards proliferation of immunosuppressive regulatory $\mathrm{T}$ cells, leading to overall increased IL-10 release and diminished IFN$\gamma$ production. IL-10 itself increases the susceptibility of TB reactivation, as it allows $M$. tuberculosis to evade immune responses (48- 52).

The same properties that make monoclonal antibodies efficacious in granulomatous diseases such as $C D$ also increase the susceptibility to granulomatous infections like TB. Latent TB is characterized by the presence of granulomas sequestering the bacillus, preventing its multiplying and dissemination. The TNF-mediated formation and maintenance of bacteria-containing granulomas is essential for M. tuberculosis infection control, and anti-TNF monoclonal antibodies compromise the integrity of bacteria-containing granulomas (47, 48, 53-55).

Due to the key role played by TNF- $\alpha$ in preventing TB reactivation, screening for latent TB consisting of detailed medical history, chest X-ray, and laboratory tests that evaluate immunologic responses to the presence of $M$. tuberculosis is recommended in patients requiring anti-TNF treatment. Some of the most common tests are the tuberculin skin test (TST) and an IFN- $\gamma$ release 
assay such as the QuantiFERON-TB Gold test (QFT-G).The concomitant use of IFN- $\gamma$ release assays and TST is recommended in pediatric patients. Prophylactic treatment is recommended in all patients with persistent $M$. tuberculosis immune responses prior to initiating anti-TNF treatment (5658). On the other hand, a normal chest radiograph prior to anti-TNF treatment is a poor predictor of future active TB development $(59,60)$.

The TST, also known as purified protein derivative or Mantoux test, is a screening tool for latent TB infection, in which tuberculin, an extract of $M$. tuberculosis, is injected intradermally and the immune response in the skin is measured after 48$72 \mathrm{~h}$. A TST of $\geq 5 \mathrm{~mm}$ among patients receiving immunosuppressive treatment is considered positive, and treatment for latent $\mathrm{TB}$ is recommended. A positive TST was observed in $20.2 \%$ of an IBD cohort from a Brazilian region with a high endemic TB rate, and these were similar to the general local population (54). In contrast, latent TB infection was positive in $7.0 \%$ of IBD patients undergoing anti-TNF treatment at a hospital in Spain over a 12 years period based on TST and chest X-ray (61). In another Spanish IBD sample undergoing long-term IFX or ADM treatment, a low TST conversion rate of $2.7 \%$ was observed in patients with negative baseline latent TB infection (62). The rate of TB was $0.2 \%$ in a Northern California sample of anti-TNF users over a 9 years period, corresponding to 49 cases per 100000 person-years (63). The absence of TB in another large American CD sample treated with IFX reflects its low endemic rate in this setting, estimated at 2.8 cases per 100000 person-years in the general population (64).

IFN- $\gamma$ release assays measure IFN- $\gamma$ release in blood by TB-specific effector T cells. These assays provide greater specificity and possibly greater sensitivity than TST (65). The usefulness of TB screening was assessed in IBD patients receiving anti-TNF treatment with baseline tests negative for latent $\mathrm{TB}$ in Spain. Chemoprophylaxis with isoniazid without discontinuation of anti-TNF treatment prevented active TB in all patients showing conversion by TST. IFN- $\gamma$ release assays produced persistently negative results in these patients. The disagreement between the tests suggests previous infection followed by antigen clearance, resulting in a lack of IFN- $\gamma$ production (62). Among two patients with a positive TST and negative QFT-G assay in another study, one was treated for TB during childhood, while the other received isoniazid prophylaxis, and both did well on $\operatorname{ADM}(66)$.

With a TST negative predictive value of $95.8 \%$ among immunocompromised patients and 100\% among immunocompetent patients, it is highly advantageous to perform such assays prior to commencing immunosuppressive treatment (67). Periodic retesting is also encouraged in patients with initially negative results. While undergoing anti-TNF treatment, 7 patients developed TB in a study (1.6\% of the sample), of which only 1 tested positive for latent TB infection (61). False negative TST or IFN- $\gamma$ release assay results increase the risk of TB reactivation in chronic inflammatory disease patients receiving anti-TNF treatment (67).

TB prophylaxis administered prior to commencing anti-TNF treatment generally prevents the development of active TB (61). In a real life IBD cohort treated with anti-TNF agents, the rate of QFT-G assay positivity was $1.5 \%$ (5 of 340 patients). Of 4 patients identified prior to anti-TNF treatment (two positive for TST, one untested and one negative), three received prophylactic TB treatment and showed no signs of active TB when exposed to anti-TNF treatment. The fourth patient was considered low risk due to negative TST and normal chest X-ray, and developed no pulmonary symptoms while on ADM. A fifth patient was positive for QFT-G while on ADM and was referred to an infectious diseases clinic (66).

Chen et al. (68) report two patterns of TB active disease in anti-TNF patients, the first of which involves the reactivation of latent $\mathrm{TB}$ infection in patients with positive QFT-G assay results, usually in the first 3 months of anti-TNF treatment. The second pattern involves TB infection in patients with initially negative QFT-G assay and TST, usually after $\geq 2$ years of anti-TNF treatment. This biphasic pattern of active TB emphasizes the risk of TB infection in anti-TNF patients, despite an initially negative screen at the start of treatment (68). De novo contamination was observed in patients receiving anti-TNF treatment when coming into contact with infected individuals or traveling to regions with high endemic TB rates $(59,66)$. Travel to or immigration from areas with a high endemic TB rate may explain some cases diagnosed in areas with a low endemic rate (61). Among patients born in regions with low endemic TB rates, being a 
healthcare worker might be a risk factor of contacting the disease (60).

No gender differences were found with respect to the development of TB (40). In case-control comparisons, using controls with communityacquired TB, disease outcomes and treatment strategies were similar (41). However, TB reactivation during anti-TNF treatment generally follows an abnormal disease course. While pulmonary manifestations are more predominant in controls, anti-TNF treatment patients often experience extra-pulmonary disseminations, suggesting poor disease control by the host $(41,48$, 49). Of 7 patients who developed TB in a study, 5 were receiving concomitant immunosuppressants (61).

The most common risk factors for IFX-induced TB in a large series of 130 cases submitted to the US Food and Drug Administration (FDA) between 2001 and 2006 include the concomitant use of immunosuppressants (68.4\%), a history of latent TB $(25.4 \%)$ and being born into or having spent extensive time in a TB endemic area $(19.2 \%)$, as well as diabetes and chronic renal disease $(63,69)$. As these represent spontaneous reports, the accuracy of these results may in fact be low (69). TB restricted to the lungs was reported in $36.9 \%$ of cases and extra-pulmonary TB in $45.4 \%$ of cases. Among patients with extra-pulmonary manifestations, disseminated disease was reported in $52.5 \%$ of cases $(23.8 \%$ of total), with others affected by peritoneal disease, lymph node disease, bone or joint disease, enteric disease, meningeal disease, hepatic disease, pericardial disease or pelvic disease. Hospitalization was required in $51.5 \%$ of cases, with $14.6 \%$ being fatal (69).

Table 1 summarizes case reports of active TB in IBD patients undergoing anti-TNF treatment. Common manifestations of $\mathrm{TB}$ at the time of hospitalization include fever, fatigue, weakness, weight loss, dry cough, diarrhea and vomiting (7081). Another common manifestation is systemic inflammation, exemplified by elevated C-reactive protein (CRP) levels (72, 74, 76, 77, 80). Abdominal pain and tenderness have also been reported $(74,76,80)$.

Other manifestations depend largely on the organs affected, which may include the lungs, liver, spleen, brain, peritoneal cavity and joints. Cases presenting solely with pulmonary manifestations generally have an uncomplicated disease course
(70, 71). Mediastinal adenopathy accompanied pulmonary $\mathrm{TB}$ in another case (72). A case of thoracic TB disseminated to the lungs was characterized by widened mediastinum (73). Several cases show pulmonary TB with concomitant liver or spleen involvement. Pulmonary TB with nodular lesions in the liver and spleen is described in one case (74), while pulmonary nodules accompany a case of hepatosplenic TB (75). Micronodular spleen lesions (76), hepatosplenomegaly with micronodular spleen lesions (77) and hepatic cytolysis with bone marrow involvement (78) accompanied three cases with miliary pattern and lymphatic involvement. Miliary TB was accompanied by monoarthritis in another case (79). A rare case of disseminated TB involving the brain with cerebral tuberculomas, and pulmonary, lymphatic and skin manifestations is also described (78). Primary tuberculous peritonitis without lung involvement was diagnosed in another patient (80). A case of anal TB showed a persistent anal ulcer (81). Additional cases of pulmonary and extrapulmonary TB, including renal, nodal and peritoneal TB are also reported in a single center study over a period of 12 years (61).

The late diagnosis of active TB can lead to delayed treatment and bacterial clearance, and a more complicated disease course $(77,80)$. Several other cases of TB were identified as adverse events in patients treated with IFX, ADM, CZP and GLM in clinical trials. These cases are not presented in detail $(26,29,32,34,82,83)$. A case of fatal TB occurred in a patient treated with GLM who tested positive for latent $\mathrm{TB}$ infection and received isoniazid prophylaxis (34).

In several cases, worsening of pre-existing TB, a phenomenon known as paradoxical reaction, occurs after initial symptoms improvement $(71,72$, $74,76,81)$. Lymphadenopathy is the most common manifestation of paradoxical reaction $(71,72,74$, $76,81)$. The initial symptoms of fever, worsening of fatigue, cough, weight loss and inflammation return $(71,74)$. Bacterial cultures are generally negative, suggesting clearance of the infectious microorganism (81). Paradoxical reactions occur as a result of immune reconstitution inflammatory syndrome upon discontinuation of immunosuppressants such as anti-TNF treatment $(72,76)$. 


\section{Non-tuberculous Mycobacterial Diseases}

The rate of NTM, also known as environmental mycobacteriosis, was $0.2 \%$ in a Northern California sample of anti-TNF users over a 9 years period, corresponding to 74 cases per 100000 person-years overall, and 116 and 122 cases per 100000 personyears among IFX and ADM patients, respectively. Background rates of NTM of 4.1 cases per 100000 person-years are reported in the general American population (63). Mycobacterium avium, rapid growing Mycobacteria and Mycobacterium marinum were the most frequently reported NTMs among anti-TNF patients in the US FDA MedWatch database (84). Older age was the main risk factor for NTM (63). NTMs in IBD patients receiving anti-TNF treatment include $M$. marinum and $M$. avium, both of which are free-living microorganisms causing opportunistic infections in humans, particularly immunocompromised individuals. Case reports are presented in Table 2 (85-92).

IBD patients who develop M. marinum generally present cutaneous manifestations around an injury site. Most $M$. marinum infections result from exposure to sea water or aquatic animals. Sources of $M$. marinum include fishes and fish tanks $(85,86,89,90)$, as well as recent trips to tropical seas $(87,88)$. Manifestations of cutaneous M. marinum infections can include erythematous, papular or scaly skin lesions $(85-88,90)$, often accompanied by subcutaneous nodules $(85-87,89$, 90) and inflammation with slightly elevated CRP levels $(85,87-90)$. Microscopic examination of dense skin biopsies reveal lymphohistiocytic infiltrate and granulomatous inflammation $(87,89)$. A sporotrichoid pattern is sometimes reported (8890).

Two cases of M. avium complex infection are described, with a pulmonary presentation in one (91) and lymphadenopathy in the other (92). Immune reconstitution inflammatory syndrome worsened the course of the first (91). M. avium complex infection is reported in another CD patient treated with IFX in a cohort study (64).

\section{Listeria monocytogenes}

Listeriosis is a common bacterial infection caused primarily by Listeria monocytogenes, a virulent food-borne pathogen that affects pregnant women and old or immunocompromised individuals. Based on data from the FDA Adverse Event Reporting
System, $38 \%$ of L. monocytogenes infections attributed to biologicals occurred in IDB patients. Listeriosis was most common in IFX patients with concomitant immunosuppressive treatment (93). L. monocytogenes infections in IBD patients treated with IFX or ADM are detailed in several case reports reviewed in Table 2 (94-106).

The estimated $L$. monocytogenes infection rate was 43 cases per 1000000 persons treated with IFX compared to 3 cases per 1000000 persons in the general American population, based on data from the FDA and the Centers for Disease Control and Prevention Emerging Infections Program (104). In a more recent report, the incidence of $L$. monocytogenes infection was 0.256 (95\% CI 0.115 0.570) per 1000 patient-years in the Spanish Registry of Adverse Events of Biological Therapies in Rheumatic Diseases. This was higher than the 0.0034 per 1000 person-years incidence in the general European population, giving rise to a risk ratio of $75.3(95 \%$ CI 33.8-168.0, $\mathrm{p}<0.001)$ of developing $L$. monocytogenes infection for RA patients undergoing anti-TNF treatment (107). Davies et al. (108) found that the inclusion of dietary warnings about the risk of Listeria and Salmonella infections in the product information of anti-TNF biologicals led to a significant reduction in the rate of infections with these bacteria in a cohort of RA patients.

The main clinical presentations of $L$. monocytogenes infections are sepsis and meningitis. Almost all cases present sepsis, diagnosed by the ability to culture $L$. monocytogenes in blood samples (94-106), with the rest showing $L$. monocytogenes growth from cerebrospinal fluid (CSF) (104-106). Meningitis was diagnosed in several cases (99-106). Another case of $L$. monocytogenes meningitis is reported in a $\mathrm{CD}$ patient treated with IFX in a cohort study (109). Three additional cases of $L$. monocytogenes infection were reported in CD patients treated with IFX, 2 of which developed meningitis. Meningitis was fatal in one of these cases, while it led to permanent eye paralysis in the other (104).

Symptoms were similar regardless of whether L. monocytogenes could be cultured in blood, CSF or both, and included weakness, lethargy, fever, diarrhea, abdominal pain, anorexia, malaise, hypotension, nausea and emesis, and diaphoresis. Inflammation with leukocytosis and/or elevated $\mathrm{CRP}$ is the predominant feature of $L$. 
monocytogenes infection (94-106). In addition, symptoms such as headache, neck stiffness, rigors, dizziness, confusion, disorientation, delirium and meningeal irritation were noted in cases involving meningitis (97, 99-106). Splenic abscesses developed in one case (95), and slightly elevated liver transaminases were observed in another case (105). In several cases, cloudy CSF with increased levels of protein and/or leukocytosis was also noted $(97,101,103,105,106)$.

The disease course was complicated by fungal sepsis with Candida albicans in one report (99). Oftentimes, the source of infection is unclear. For example, ingestion of processed meats is reported in one case (94), while no history of having eaten anything suspicious is noted in others $(99,102)$. No mention is made in the remaining cases. Coinfection with HIV, which is a risk factor for acquiring Listeria infection, is reported in one patient. The effects of the co-infection on the course of either disease are unknown, as HIV viremia was undetectable and the $\mathrm{CD}^{+}$cells counts exceeded $350 / \mathrm{mm}^{3}$ at the time of the bacterial infection (103).

\section{Legionella pneumophila}

Legionella pneumophila is an intracellular gramnegative bacterium that is a significant cause of community-acquired pneumonia. L. pneumophila pneumonia can further advance to a severe condition known as legionellosis or Legionnaires' disease (110). The incidence of legionellosis among anti-TNF patients reported in the French research axed on tolerance of biotherapies registry was 46.7 (95\% CI 0.0-125.7) per 100000 patient-years over a 4 years period compared to 2.3 per 100000 patientyears in the general French population (OR 13.1, 95\% CI 9.0-19.1, $\mathrm{p}<0.0001)$. Adjusted to the risk of developing legionellosis in the general French population, IFX (OR 15.3, 95\% CI 8.5-27.6, $\mathrm{p}<0.0001)$ and ADM (OR 37.7, 95\% CI 21.9-64.9, $\mathrm{p}<0.0001$ ) represent risk factors (110). This is comparable with an earlier report from the same population that saw a 16.5-21-fold higher incidence of L. pneumophila among anti-TNF patients compared to the general French population. As such, legionellosis should be considered in antiTNF patients presenting pneumonia (39).

L. pneumophila infections are detailed in a few case reports in IBD patients treated with IFX, summarized in Table 2 (111-115). L. pneumophila pneumonia is also reported in a CD patient treated with ADM in an open-label clinical study (116). Symptoms of L. pneumophila pneumonia include fever, cough, and fatigue leading to syncope (113115). Respiratory insufficiency progressing to respiratory failure may also develop $(113,114)$. Inflammation with elevated CRP levels and leukocytosis is further reported (113, 115), progressing to pulmonary consolidation in one case (115). Other pulmonary symptoms include tachypnea (114), as well as pulmonary infiltrates that progressed to abscess (112-114). Stethoscopic findings such as rales were also common (113-115). A lung biopsy belonging to a patient with $L$. pneumophila pneumonia grew CMV, yet the implications of the co-infection with this virus are not detailed (114). Interestingly, in one case, the source of infection was identified as communityacquired legionellosis, as L. pneumophila was cultured from water collected in the patient's shower (113).

\section{Staphylococcus aureus}

Staphylococcus aureus is a bacterium frequently found in the human respiratory tract and on the skin. Pathogenic S. aureus infections are described in Table 2 in several IBD patients treated with IFX. A case of $S$. aureus infection also occurred in a UC patient treated with GLM in a recent clinical trial (34). Manifestations of S. aureus infections were varied.

Skin lesions, adult respiratory distress syndrome and severe sepsis were diagnosed in a patient. Symptoms included fever, dyspnea, coughing and elevated CRP levels, as well as renal failure. Hyperventilation with severe hypoxemia and acidosis, and large pneumonic infiltrates exemplify the pulmonary symptoms (117). Septic arthritis was diagnosed in two patients. Staphylococcal osteomyelitis masked an osseous mycobacterial infection in one patient (118), while septic arthritis and lumbar empyema were diagnosed in a patient with severe polyarthalgias, leukocytosis and elevated CRP levels (119). A subretinal abscess with bacterial endophthalmitis caused by an intraocular cilium presented as blurred vision, pain, inflammation and vitreous opacity (120). Fever, severe inflammation with leukocytosis and elevated CRP levels, elevated aspartate transferase (AST) of $87 \mathrm{IU} / \mathrm{L}$ and alanine transferase (ALT) of $149 \mathrm{IU} / \mathrm{L}$, and heterogeneous liver lesions preceded a liver abscess (121). 


\section{Other Bacterial Infections}

Neisseria meningitidis is another bacterium associated with meningitis. A patient diagnosed with Neisseria meningitidis meningitis presented with fever, agitation, altered sensorium, nuchal rigidity and leukocytosis in CSF (122). Nocardia infections manifest as either cutaneous nocardiosis or Nocardia pneumonia in CD patients treated with IFX. Case reports are detailed in Table 2. Symptoms of cutaneous nocardiosis included erythematous papulopustular lesions in one patient (123) and papules progressing to skin abscess in another (124). Two cases of Nocardia pneumonia show fever, chest pain, dyspnea, cough, tachypnea and inflammation, as well as pulmonary crackles and pulmonary consolidation $(125,126)$. A case of Nocardia infection also occurred in a UC patient treated with GLM in a recent clinical trial (34).

Two cases of Pseudomonas aeruginosa pneumonia occurred in UC patients treated with IFX in cohort studies $(127,128)$. P. aeruginosa and Enterococcus species were also cultured in a patient with L. pneumophila pneumonia (114).

One case of septic arthritis with Salmonella enteritidis and two cases of sepsis with Salmonella typhimurium and Salmonella enterica manifested as fever, abdominal pain, leukocytosis and elevated CRP levels (129-131). Another case of Salmonella enterica infection, starting as urosepsis, led to the development of acute renal failure, acidosis and respiratory failure (132).

The incidence of Clostridium difficile colitis was $28.6 \%$ in a small sample pediatric of CD patients undergoing concomitant methotrexate and anti-TNF-a treatment. This led to complicated disease course and increased the odds of treatment failure (133). While concomitant corticosteroids were a risk factor for Clostridium difficile infections in IBD patients treated with IFX, IFX alone did not increase the chance of acquiring this type of bacterial infections (134).

\section{OPPORTUNISTIC FUNGAL INFECTIONS Pneumocystis jirovecii}

Pneumocystosis was the most common non-viral opportunistic infection in a large cohort of new antiTNF patients suffering from IBD or autoimmune diseases (21). In a review of the FDA Adverse Event Reporting System database, 84 cases of Pneumocystis jirovecii pneumonia were identified over a period of 6 years among patients treated with
IFX for various conditions including CD, UC, RA, ankylosing spondylitis and psoriatic arthritis (135). Concomitant exposure to immunosuppressants and IFX for a duration of $>3$ years are the main risk factors for $P$. jirovecii colonization $(135,136)$. The onset of pneumonia generally occurs after a mean $21 \pm 18$ days since starting IFX, or a mean $2.1 \pm 1.3$ IFX infusions (135). $P$. jirovecii pneumonia results in death in over one quarter of cases (135).

Case report of $P$. jirovecii infection are detailed in Table 3 (137-144). Symptoms of $P$. jirovecii pneumonia include fever, cough, fatigue, nausea, diarrhea, abdominal tenderness and pain, and deteriorating respiratory status with dyspnea and tachypnea, occasionally progressing to respiratory failure (137-144). Other pulmonary manifestations encompass pulmonary rales, pulmonary opacity, interstitial infiltrates consistent with pneumonia, as well as pulmonary microabscess (138-144). Inflammation with elevated CRP was observed in some cases $(138,141,143)$. Leukopenia was also a common feature $(138,141,143,144)$. In contrast, leukocytosis was reported in a case with concomitant pulmonary Nocardia asteroides infection (140).

\section{Histoplasma capsulatum}

Histoplasma capsulatum is the most common fungal infection in the US. Opportunistic infections with this microorganism are most common around the valleys of the Ohio and Mississippi rivers (9, 10). Opportunistic $H$. capsulatum infections affect primarily the lungs. Case reports in IBD patients are described in Table 3 (145-149).

Common symptoms of $H$. capsulatum infections include fever, fatigue, chills, night sweats, malaise, dizziness, nausea, poor appetite followed by anorexia and weight loss, abdominal pain, headaches, muscle aches, joint pain, as well as coughing and dyspnea (145-149). The most common pulmonary manifestations are nodules and opacities consistent with interstitial pneumonia (145-147). Disseminated histoplasmosis is often accompanied by lymphadenopathy (146, 147). Diffuse alveolar infiltrates were shown by chest $\mathrm{X}$ ray, and granuloma consisting of nodules of epithelioid histiocytes and lymphocytes were shown by biopsy in one patient (148).

Other cases of disseminated histoplasmosis include one case with anus involvement with necrotizing perianal soft tissue infection and pain, 
fibrotic inflammation, perianal fissure and focal abscess (145), hepatosplenomegaly with elevated inflammatory markers, mildly elevated transaminases and elevated lactate dehydrogenase, and concomitant Pneumocystis pneumonia (146), and a case of edematous and erythematous epiglottis, with odynophagia, hoarseness and an exophytic lesion (149).

Reactivation of histoplasmosis was suspected in two patients previously exposed to a histoplasmosis pendemic $(144,148)$. A case of fatal Histoplasma pneumonia is reported in a UC patient treated with IFX in a large study (26).

\section{Aspergillosis}

Aspergillus fumigatus represents another common fungal infection in immunocompromised individuals. Four cases of aspergillosis are described in CD patients, with three fatalities and one unknown outcome in a patient lost to follow-up (150-153). Fever, cough, dyspnea, leukocytosis and elevated CRP levels, as well as pulmonary infiltrates and respiratory insufficiency are reported in two cases of fatal aspergillosis $(150,151)$. Fatal disseminated $A$. fumigatus involving multiple organs is chronicled in a patient who developed dyspnea, respiratory insufficiency, and pulmonary infiltrates and opacities, followed by pericarditis, ischemic injury and multiorgan failure (152). Concomitant Nocardia brasiliensis, A. fumigatus and $A$. niger infections are described in a patient presenting with cough, abdominal pain, elevated CRP and pulmonary nodular lesions (153).

\section{Cryptococcus neoformans}

Asymptomatic pulmonary cryptococcosis was identified in two patients during hospitalization for CD-related medical procedures $(154,155)$. No respiratory symptoms were present. Pulmonary nodules without lymphadenopathy were noted by chest CT scan $(154,155)$. A case of possible pulmonary cryptococcosis with fever, elevated $\mathrm{CRP}$, and pulmonary nodules and infiltration is reported elsewhere (156). Two cases of pulmonary Cryptococcus neoformans infection, with initial presentations of fever, night sweats, headache, chest and abdominal pain, cough and dyspnea are reported in a CD patient treated with IFX and a CD patient with concomitant ankylosing spondylitis treated with $\operatorname{ADM}(157,158)$. The first patient developed slightly elevated liver transaminases and pulmonary nodules, as well as a linear ulcer near the terminal ileum not consistent with $C D$ exacerbation, with the additional colitis symptoms likely related to the fungal infection. Further dissemination to CSF without neurological symptoms was noted (157). Pulmonary opacities and crackles, as well as lymphadenopathy, are reported in the second patient (158). Cryptococcosis was speculated to be related to recent contact with poultry or pigeons in two patients $(155,158)$.

\section{Candidiasis}

Candidiasis encompasses the entire spectrum of infections caused by fungi of the Candida genus. Disseminated candidiasis attributed to C. glabrata is described in a CD patient treated with IFX (159). The disease course started off with fever. A granulomatous pulmonary lesion was first identified, followed by pulmonary nodules, alveolar condensations, bilateral pleural effusion and slightly elevated bilirubin and transaminases (159).

Fungal sepsis with $C$. albicans further complicated the clinical course of a previously described case of Listeria meningitis (99). Catheterrelated C. parapsilosis was detected in a patient during treatment for methicillin-resistant $S$. aureus. Successful treatment of this fungal infection did not affect the disease course or the treatment of the previously identified bacterial infection (121). Catheter-related candidemia was also identified in a patient with Legionella pneumonia (114).

Co-infection with $C$. albicans led to an oropharyngeal infection in a patient with $P$. jirovecii pneumonia, as well as pulmonary infection with Nocardia spp. This patient was further afflicted by a urinary tract infection associated with Proteus mirabilis and airways infection associated with Acinetobacter baumanii (140). Oral infection with $C$. albicans that did not necessitate treatment was observed in another patient with $P$. jirovecii pneumonia (139). Co-infection with Candida species was detected in a patient who died from multiorgan failure due to aspergillosis (152).

Oral candidiasis was a non-serious opportunistic infection in a $\mathrm{CD}$ patient receiving open-label ADM (116). Esophagitis and vaginitis secondary to Candida were identified as important infectious adverse events in $\mathrm{CD}$ patients treated with ADM in clinical practice (83). Esophageal candidiasis was also identified as an opportunistic infection in randomized, placebo-controlled studies 
of UC patients treated with ADM or GLM (33, 160).

\section{Other Opportunistic Fungal Infections}

A pulmonary infection with Actinomyces graevenitzii manifesting as fever, night sweats and cough, along with pulmonary crackles, consolidation and opacity is described in a CD patient treated with IFX (161). Malaise, fatigue, night sweats and cough, along with pulmonary crackles and infiltrate were noted in a UC patient treated with IFX who developed Blastomyces dermatitidis (162).

Disseminated Coccidioides immitis with meningeal, bone, soft tissue and pulmonary involvement was fatal in a CD patient treated with ADM. The disease further involved splenic granulomatous nodules, pulmonary nodules and multinodular thyroid disease. Lymphadenopathy, erythematous skin lesions, joint inflammation with soft tissue swelling, elevated liver transaminases, splenomegaly, bilateral infiltrates, and pleural effusion were identified subsequently. A brain magnetic resonance imaging revealed focal fluidattenuated inversion recovery hyperintensities and nodular foci in the cerebral white matter. The patient also developed acute renal insufficiency, and eventually died due to the numerous manifestations of disseminated coccidioidomycosis (163).

\section{VIRAL INFECTIONS}

\section{Hepatitis B Virus Reactivation}

The main viral infection associated with anti-TNF treatment in IBD patients is HBV, particularly reactivation of latent HBV. Since TNF- $\alpha$ suppresses viral replication, TNF- $\alpha$ inhibitors may lead to HBV reactivation. While IFX is associated with a greater incidence of $\mathrm{HBV}$ reactivation than ADM, screening for chronic HBV infection with hepatitis B surface antigen ( $\mathrm{HBsAg}$ ) and hepatitis B core antibody (anti-HBc) is recommended in all patients prior to initiating anti-TNF treatment. Viral replication can be reduced by treatment with antiviral therapy (164).

The HBV infection status is classified based on the serological assessment of several HBV-specific antigens and antibodies. The specific combination of biomarkers denotes each patient's infection status. HBsAg is an HBV surface protein that can be detected in high quantities in serum during acute or chronic infection. The body can produce antibodies against $\mathrm{HBsAg}$ (anti-HBs), and the presence of anti-HBs indicates recovery from infection or immunity. The presence of anti-HBc denotes a previous or ongoing infection, while that of the hepatitis $\mathrm{B}$ core antigen $(\mathrm{HBcAg})$ or its extracellular form $\mathrm{HBeAg}$ indicates active viral replication. On the other hand, antibodies against $\mathrm{HBeAg}$ (anti-HBe) indicate a decline in viral replication. Finally, the presence of $\operatorname{IgM}$ anti-HBc indicates acute infection (in past $<6$ months) while its absence indicates chronic infection (165).

Baseline liver dysfunction was observed among $17.2 \%$ of HBsAg-positive IBD patients. Among patients who have received immunosuppressants, the rate of liver dysfunction was higher among HBsAg-positive patients than among HBsAgnegative ones (166). HBV reactivation in IBD patients treated with IFX is described in several patients in Table 4 (167-174).

In a systematic review analyzing patients treated with anti-TNF agents with positive HBV markers, chronic HBV infection was classified as positive by the presence of HBsAg and resolved HBV infection was classified as positive by the presence of anti-HBc and/or anti-HBs antibodies (172). Both a diagnosis of IBD and treatment with IFX were risk factors for raised baseline liver transaminases among chronic HBV patients, as well as symptomatic disease. Elevated baseline transaminases were a further risk factor for liver failure $(p=0.016)$. Among patients with HBV reactivation, elevated serum HBV DNA alone is reported in $23.1 \%$ of subjects, $30.8 \%$ of patients experienced elevated serum HBV DNA with slightly raised liver transaminases levels, and $46.1 \%$ had elevated serum HBV DNA with biochemical manifestations of liver disease (172).

Based on baseline data using serum samples collected prior to initiating ant-TNF treatment, patients could be either known HBV carriers (serology performed prior to initiating ant-TNF treatment), have an unknown HBV status (serology performed after HBV reactivation using archival serum samples collected prior to initiating anti-TNF treatment), or presumed negative (serology performed prior to initiating ant-TNF treatment) in case reports. Symptoms of HBV reactivation can include fever, malaise, fatigue, nausea, loss of appetite, weight loss, weakness, dyspepsia, and joint and/or abdominal pain (169, 171-173). Hepatic manifestations are the predominant symptoms, 
including hepatitis or jaundice with elevated AST, ALT, alkaline phosphatase (ALP), $\gamma$-glutamyl transpeptidase and total bilirubin. New onset ascites, presenting as severe hepatitis with ballooning degeneration, hepatocyte necrosis and fibrosis on biopsy was detected in one case (170). Liver dysfunction, with moderate infiltration of chronic inflammatory cells and mild fibrosis in the portal area, occurred in another patient (168).

Four patients were known to be chronic HBV carriers. The first three patients all show positive serum HBsAg (167-169). HBeAg and anti-HBe antigen were also positive in the first of these patients, (167), and anti-HBe and anti-HBc were positive in the other two patients $(168,169)$. ALT and AST levels were normal and HBV DNA was undetectable at baseline in the patients in which these parameters were assessed (167, 168). Serology analysis is unavailable for the fourth, but chronic HBV was noted in his medical history (170).

HBV reactivation is described in four patients with unknown HBV status prior to initiating IFX treatment. Two of these patients were found to be HBV carriers based on markers of HBV infection in serum collected at previous visits $(169,171)$. Archival serum was not available in a third patient (172), while results are not described in the fourth (173). In the two patients for whom archival serum was available, positive HBsAg and HBV DNA was determined in both $(169,171)$, while $\mathrm{HBeAg}$ and $\mathrm{IgG}$ anti-HBc antibodies were further found in one (169). A fifth patient with a previously unknown HBV carrier state was presumed negative at baseline, owing to negative serum HBsAg and liver transaminases within normal limits. Anti-HBc and anti-HBe antibodies were not assessed (174).

$\mathrm{HBV}$ reactivation, diagnosed as chronic cirrhotic hepatitis (AST $127 \mathrm{IU} / \mathrm{L}$, ALT $122 \mathrm{IU} / \mathrm{L}$ and HBV DNA $3.9 \times 10^{8}$ copies $/ \mathrm{mL}$ ), occurred in a $\mathrm{CD}$ patient. Introduction of lamivudine prior to IFX exposure led to continuous AST and ALT normalization, yet high viremia persisted. The patient remained asymptomatic, with continued viral replication upon IFX introduction (175). No HBV reactivation was reported upon IFX exposure in another patient with a history of HBV infection (mildly elevated AST and ALT, and positive HBsAg, IgG anti-HBc, HBeAg and HBV DNA). Lamivudine was used to treat the initial HBV infection, resulting in resolution of symptoms, and was further maintained during IFX treatment (169).

The rate of HBV reactivation was 5.4\% among patients with resolved HBV infection treated with anti-TNF agents in a systematic review. Among these 9 patients, symptoms of liver disease occurred in 2, with one death due to fulminant liver failure (172). No HBV reactivation was detected in two small sample of RA patients with resolved HBV infection treated with anti-TNF agents $(176,177)$. In general, anti-HBs titers decrease while on antiTNF agents in patients vaccinated against HBV. Liver decompensation or significant increases in ALT levels were absent in patients with chronic HBV infection receiving anti-TNF agents. Viral reactivation while receiving lamivudine was observed in a patient with a mutant HBV strain (177).

The rate of HBV vaccination in a small sample of pediatric IBD patients was $87.0 \%$. Among these, HBV immunity was achieved in $56.3 \%$ (serum antiHBs level $\geq 10 \mathrm{mIU} / \mathrm{mL}$ ). A booster vaccination led to immunity in $76.5 \%$ of patients who did not achieve initial immunity. No patient was classified as exposed to or chronic carrier of HBV (negative HBsAg or anti-HBc). Older age $(\mathrm{p}=0.001)$, lower albumin levels $(\mathrm{p}=0.01)$ and the presence of pancolitis $(p=0.029)$ were risk factors for not developing protective antibodies. The dose, frequency and duration of IFX treatment, or concomitant exposure to immunomodulators, did not affect the rate of developing HBV immunity following vaccination (178).

\section{Hepatitis C Virus Infection}

TNF- $\alpha$ plays a key role in the host defense against $\mathrm{HCV}$ infection. However, high levels of TNF- $\alpha$ suppress IFN and its antiviral activity in HCVinfected patients (179-184). Anti-TNF- $\alpha$ agents were found to stabilize hepatitis, or even improve liver transaminases levels and HCV viremia in a review of $153 \mathrm{HCV}$ patients treated with for RA, $\mathrm{CD}$ and other chronic inflammatory diseases (185). Liver functions remain unchanged in CD patient coinfected with HCV during treatment with IFX (186188).

In a separate study, an $\mathrm{HCV}$ carrier patient treated with ADM for IBD experienced stable yet consistently detectable viremia with normal liver function test results (189), while 2 IFX patients developed biochemical changes in a retrospective 
cohort of 4 IBD patients co-infected with HCV (190). Worsening of hepatic biochemical tests was observed in an UC patient with HCV and HIV coinfection undergoing anti-TNF treatment with concomitant 6-mercaptopurine. Deteriorating hepatic biochemical tests were attributed to progressive liver disease associated with HIV, and liver function improved upon reducing the dose of 6-mercaptopurine (191). Asymptomatic elevations of serum transaminases and progression of viremia was observed after the $14^{\text {th }}$ IFX infection in an RA patient co-infected with HCV. The patient was also receiving methotrexate (192). Based on these findings, anti-TNF- $\alpha$ agents are generally considered safe in patients with chronic hepatitis, yet careful monitoring of liver function and viremia is strongly encouraged. A recent report demonstrated that the use of a single dose of TNF- $\alpha$ inhibitor was safe and well tolerated in HCVinfected study participants, corroborating the current body of evidence (193).

\section{Human Immunodeficiency Virus}

Treatment with IFX did not affect the $\mathrm{CD}^{+}$cell count and the viral load in a CD patient co-infected with HIV (194). CD4 $4^{+}$cell counts and viral loads were also unaffected by anti-TNF treatment in small RA samples co-infected with HIV $(195,196)$. IFX led to a quick increase in the $\mathrm{CD}^{+}$cell count in another patient. Long-term effects are unknown as the patient was lost to follow-up (197). In another CD patient co-infected with HIV and not receiving antiretroviral treatment, IFX decreased the $\mathrm{CD} 4^{+}$ cell count through a mechanism believed to involve cell cycle inhibition and IL-10 mediated T cell apoptosis. The viral load also decreased in this patient (198).

No increase in the risk of infection is reported in an RA patient co-infected with HIV and treated intermittently with IFX over a 10 year period. The patient's viral load remained undetectable or low while on antiretroviral medication, with $\mathrm{CD}^{+}$cell counts within reference range (199). Based on these findings, anti-TNF treatment is expected to have minimal effect on HIV viral load as well as on the $\mathrm{CD}^{+}$cell counts. Furthermore, IFX and ADM appear safe with regards to the risk of opportunistic infection in patients with higher $\mathrm{CD} 4^{+}$cell counts, especially those undergoing antiretroviral treatment (200).

\section{Cytomegalovirus}

CMV, also known as human herpes virus (HHV)-5, belongs to the herpesvirus family. CMV serology was positive in $70.0 \%$ of samples collected before IFX infusions in consecutive CD patients, indicating latent viral presence. CMV replication and reactivation was not observed (201). CMV was not detected in a pediatric IBD sample treated with biologicals or conventional therapies for over 12 months (202).

The role of CMV in IBD patients undergoing IFX treatment is unclear. On the one hand, the immunosuppressive conditions created by IFX are thought to lead to the reactivation of latent CMV infections, triggering inflammation and leading to exacerbations of colitis. As such, a dilemma exists with respect to treating IBD patients with CMV reactivation, as reducing immunosuppressive treatment can lead to worsening of IBD symptoms, while increasing immunosuppressive treatment to control IBD symptoms can lead to further CMV reactivation. Furthermore, the antigen or genetic detection of CMV in blood may not reflect CMV reactivation in the inflamed mucosa (203). However, detection of CMV in mucosal tissue is of value, particularly in patients with refractory UC. CMV reactivation was only detected in inflamed colonic mucosa. The use of antiviral therapy facilitated disease remission in $83.3 \%$ of treated patients. At the same time, patients negative for CMV reactivation benefited from an increase in the dose of immunosuppressive treatment, showing the benefits of early CMV detection in mucosa in patients with refractory UC (204). This can be explained by findings that pro-inflammatory cytokines such as IFN- $\gamma$ and TNF- $\alpha$ lead to CMV reactivation in inflamed mucosa. As such, CMV infection may initially be restricted to the inflamed mucosa where latently infected monocytes and dendritic cells reside, while active replication may lead to systemic inflammation (205). IFX treatment may lead to $\mathrm{CMV}$ clearance in refractive UC patients. Nakase and Chiba (206) show that IFX treatment led to negative CMV DNA in colonic mucosa in three patients with positive CMV DNA prior to IFX treatment.

Cases of CMV reactivation in $\mathrm{CD}$ patients treated with IFX are described in Table 4 (207-210). Common symptoms include fever, chills, fatigue, nausea and vomiting (207-210). Exacerbation of gastrointestinal symptoms occurred in three patients 
(207-209). Severe hemorrhagic ileocolitis with esophageal and duodenal ulcers were accompanied by impaired cerebral function with difficulty concentrating, impaired hearing and rapidly deteriorating short-term memory in a patient. CMV inclusion bodies were shown on colonoscopy (207). Ileocolitis with persistent disseminated intravascular coagulation and gastrointestinal hemorrhage was observed in a patient also afflicted by splenomegaly. CMV inclusion bodies were noted on splenectomy (208). In a pediatric patient, colitis with bloody diarrhea and thickening of the colon was accompanied by icteric sclera, respiratory distress and bilateral pulmonary infiltrates. CMV inclusion bodies were noted on colonoscopy. The patient subsequently died of multiorgan failure, including respiratory and subsequently hepatic failure (209). Hepatitis with AST $468 \mathrm{U} / \mathrm{L}$, ALT $282 \mathrm{U} / \mathrm{L}$, ALP $845 \mathrm{U} / \mathrm{L}$ and total bilirubin 1.1 $\mathrm{mg} / \mathrm{dL}$, as well as hepatomegaly without abnormalities of the biliary tract, was diagnosed in the fourth patient. CMV inclusion bodies were identified on liver biopsy (210).

\section{Varicella Zoster Virus}

VZV, also known as HHV-3, is associated with chickenpox in the pediatric population and with herpes zoster or shingles in adults. Chickenpox refers to primary VZV infection, characterized by low fever, nausea, malaise, headache and muscle aches, as well as vesicular, itchy rash affecting primarily the trunk and the head. Under conditions of immunosuppression, herpes zoster or shingles may occur as a result of latent VZV reactivation. This presents with blistering skin rash, typically on a more limited area of the body. The more limited presentation during VZV reactivation is due to the fact that only a few nerve cells produce the virus, hence cutaneous manifestations are limited to the area associated with the axons of those cells. The immune system prevents a more wide-spread activity. Multi-dermatomal distribution characterizes disseminated VZV (211).

VZV infection in IBD patients treated with IFX is described in several patients in Table 4 (212220). The risk of herpes zoster was assessed in antiTNF patients in the French research axed on tolerance of biotherapies registry. Herpes zoster occurred after a median 11.5 years of anti-TNF treatment. Herpes zoster occurred in patients treated with all of IFX and ADM, with $14.7 \%$ incidence for
ADM and $37.5 \%$ incidence for IFX. Among antiTNF agents, monoclonal antibodies were risk factors for VZV infections (220).

Primary VZV infection is believed to have occurred in two CD patients treated with IFX (212, 213). The first of these patients experienced fever, chills, nausea, vomiting and abdominal pain, as well as non-pruritic pustules on chest and back, resembling pustular folliculitis. In addition, elevated AST (210 IU/L) and ALT (227 IU/L), and normal ALP and bilirubin were also found. Along with hepatomegaly, this shows evidence of hemorrhage and necrosis surrounding the central veins. Fulminant hepatic failure and respiratory failure occurred. Despite the severe disease course, this was diagnosed as a primary infection due to a lack of $\operatorname{IgG}$ or IgM on varicella serology (212). In another case, multiple fluid-filled vesicular lesions spread over the entire body are described in a child. These were accompanied by mild pharyngitis without fever or associated systemic symptoms (213).

Herpes zoster is described in several cases comprising both pediatric and adult patients (213218). IFX [incidence rate (IR) 2.4 per 1000 patientyears, 95\% CI 0.0-4.7] and ADM (IR 7.1 per 1000 patient-years, 95\% CI 2.9-11.3) were associated with herpes zoster in a large Belgian cohort of patients treated with biologicals (216). Herpes zoster occurred at the site of IFX infusion in a CD patient with a history of childhood varicella, manifesting as erythematous pruritic papulovesicles. The reaction reoccurred upon subsequent infusions. Eventually, valacyclovir prophylaxis prevented viral reactivation (215). Painful swelling associated with an erythematous, purpuric rash occurred after the resolution of an initial vesicular rash in a young patient. It is unknown whether this is a primary VZV infection, but a diagnosis of herpes zoster was made based on the localization of the rash in the suprascapular and subclavicular regions. A further relapse of lesions was reported at a later date (214). Disseminated cutaneous zoster infection, manifesting as pruritic, nonpainful, vesicular lesions involving the scalp, face, trunk and extremities, with no systemic symptoms, is described in a child one year after a primary VZV infection and subsequent VZV immunization (213).

Four cases of herpes zoster with dermatomal distribution are further described. These can be further accompanied by fever, nausea, headache and 
pain $(216,218)$. A papular rash along the thoracic dermatome characteristic of herpes zoster occurred in a CD patient treated with IFX who developed a severe CMV infection (207). A case of VZV reactivation manifesting as vesicular maculopapular rash with dermatomal distribution was accompanied by meningitis with increasing headaches and photophobia in a CD patient treated with ADM. Leukocytosis and elevated protein levels in CSF were also found (217).

Seven additional non-serious VZV cases, likely reflecting opportunistic infections, are reported in two cohorts of CD patients treated with IFX (219, 220). VZV reactivation is reported in another CD patient treated with ADM (221).

\section{Herpes Simplex Virus}

HSV-1 and -2, also known as HHV-1 and -2, can cause blisters on the skin or on the mucous membranes of the mouth, lips or genitals. A case of localized oral HSV infection is reported in a CD patient treated with ADM in a cohort study. The patient was successfully treated with acyclovir (221). Non-serious HSV infection manifesting as genital herpes is reported in a 49 year old female CD patient treated with IFX (219). Valaciclovir prophylaxis successfully prevented HSV-1 reactivation in a CD patient with a history of HSV-1 infection (222).

\section{Epstein-Barr Virus}

EBV, also known as HHV-4, is another member of the herpesvirus family. EBV positivity is an important infectious adverse event as it can lead to both malignant and non-malignant complications (223). EBV serology was positive in $98.3 \%$ of serological samples collected before IFX infusions in consecutive CD patients, showing latent viral presence (201). However, EBV replication and reactivation was only observed in $11.7 \%$ of patients at week $0,3.3 \%$ at week 2 , and $3.3 \%$ at week 14 , with low viremia $(50-600$ copies $/ \mathrm{mL})$, indicating transient replication. Concomitant methotrexate was associated with EBV viremia by polymerase chain reaction (PCR) (OR 7.5, 95\% CI 1.4-40.1, $\mathrm{p}=0.025)$ (201).

Risk factors for detectable EBV DNA in whole blood include IBD, regardless of treatment, compared to healthy volunteers $(p<0.05)$, IFX compared to non-biological treatments, age $\geq 60$, and UC compared to CD (223). A 17 year-old IBD patient whose blood tested positive for EBV was treated with IFX without any reported adverse events (202). Non-serious EBV infection manifesting as mononucleosis is reported in a 15 year old female CD patient treated with IFX and 6MP (219).

\section{Other Members of the Herpes virus Family}

The remaining members of the herpesvirus family are HHV-6, HHV-7 and HHV-8. No patient became positive for HHV-6, HHV-7 and HHV-8 in blood samples at any point in a sample of 60 consecutive CD patients treated with IFX (201). HHV-6 was not detected in urine, serum or peripheral blood mononucleated cells in a pediatric IBD cohort treated with biologicals or conventional therapies for over 12 months (202).

However, several findings support the monitoring of HHV-6 levels in patients treated with biologicals. Recently, Al Jawhari et al. (224) reported that 20 of 55 (36.4\%) colon biopsies belonging to patients with gastrointestinal conditions tested positive for HHV-6 by qualitative PCR, showing that HHV-6 is present in the intestinal tract. HHV-6 was associated with diarrhea (224). Elsewhere, HHV-6 was found to induce the replication of JCV in a limited number of NTZ patients (225).

\section{John Cunningham Virus}

Progressive multifocal leukoencephalopathy (PML) is a rare but often fatal opportunistic infection caused by John Cunningham virus (JCV) reactivation in immunosuppressed patients (226). The presence of JCV was determined by PCR amplification in several matrices, including serum, urine, peripheral mononuclear blood cells and intestinal biopsies in $\mathrm{CD}$ patients with immunemediated diseases treated with IFX or nonbiological agents, and in healthy controls $(202,226$, 227). JCV was quantified by PCR in $37.0 \%$ of patients treated with IFX and in $17.0 \%$ of patients treated with non-biological agents in pooled data collected at four time points over 1 year of treatment. Differences between the two cohorts were significant with respect to JCV positivity in urine $(\mathrm{p}=0.03)$, plasma $(\mathrm{p}<0.05)$ and colorectal biopsies $(p=0.02)$ (226). JCV DNA was detected more frequently in urine than in either serum or peripheral mononuclear blood cells $(202,227)$. Viremia in urine was significantly higher in IFX 
patients compared to patients treated with nonbiological agents at one year of follow up only $(7.47$ vs. 5.36 log genome equivalents $/ \mathrm{mL}$, $\mathrm{p}=0.039$ ) (226). Finally, odds of detecting JCV in urine were higher in IBD patients than in healthy controls $(p<0.05)(202,227)$. The prevalence of transiently-positive JCV in peripheral mononuclear blood cells measured by PCR was also higher in IBD patients, yet the viral load was low and comparable between groups (227). These studies show that while IFX is associated with modest JCV reactivation in peripheral mononuclear blood cells, this did not reach levels associated with PML (227).

\section{Influenza}

The rate of developing immunity to influenza following vaccination was lower in a pediatric IBD sample receiving immunomodulatory treatment, either alone or in combination with IFX, compared to healthy controls (228). Compromised immune responses to the influenza vaccine are thought to involve impaired effector and memory B cell and antibody response. The compromised antigen responsiveness may also account for more severe influenza manifestations among individuals receiving immunomodulatory treatment compared to healthy controls (229). In a separate study, the rate of developing immunity to influenza (antibody titer $\geq 1: 40$ ) was high and comparable between antiTNF patients, patients treated with other immunomodulators, and healthy controls. However, antibody titers were significantly lower in anti-TNF patients compared to the other two groups (230).

Acute hepatic cytolysis is reported in response to H1N1 vaccination in a $C D$ patient following one IFX infusion. ALT and ASD were elevated 2-3 times over the upper limit of normal during this time, with spontaneous resolution (231).

\section{INFECTIOUS ADVERSE EVENTS WITH INTEGRIN ANTAGONISTS}

PML is the most worrisome adverse event of NTZ. The risk of PML in NTZ patients was investigated in patients treated with NTZ for RA, multiple sclerosis or CD (232). Patients previously involved in clinical trials with NTZ underwent clinical history, physical exam, magnetic resonance imaging of the brain, and CSF analysis for JCV DNA. From 3826 recruited individuals, 3 patients were diagnosed with PML. One patient survived and 2 patients died. The study concluded that the risk of
PML in patients treated with this integrin antagonist for a mean period of 17.9 months was 1 in 1000 patients. Due to the risk of PML, NTZ was voluntarily withdrawn from the market in 2005 (232). Subsequently, NTZ was used for the treatment of multiple sclerosis in the TOUCH prescribing program, under a strict post-marketing surveillance program that incorporates mandatory education, monitoring, and reporting to the FDA (233). Currently, NTZ is available, and it can be prescribed in moderate to severe CD patients who have failed standard and anti-TNF therapies, and who have biologic evidence of inflammation. A positive anti-JCV antibody status is considered to be a risk factor for PML development, particularly with prolonged NTZ use (234). Testing for JCV should be used to stratify individual patients' risk for PML prior to NTZ introduction (235).

One case of fatal PML associated with JCV is reported in a patient treated with NTZ for active CD in the ENACT-2 trial (236). In the ENCORE trial, one patient treated with NTZ developed a serious infection (perianal abscess) that was not considered to be related to NTZ use. No cases of PLM were reported in this study (237). No patient developed PML in two small samples of CD patients treated with NTZ $(238,239)$. Of 5 patients tested in one study, $4(80.0 \%)$ were positive for anti-JCV antibody (238). Six (54.5\%) of 11 patients tested in the other study were positive for anti-JCV antibody (239). One patient in each study discontinued treatment as a result of the positive test $(238,239)$.

VDZ binds the $\alpha 4 \beta 7$ integrin and is therefore used as anti-adhesion molecule therapy in IBD. Latent TB, as well as one case each of lethal culture-negative sepsis and septic-shock, were reported in CD patients treated with VDZ in the GEMINI 2 trial. There were no cases of PLM in this study (240). In contrast, no serious infections, including PML, were noted in UC patients in the GEMINI 1 trial (241). Infections were the most common adverse events in the GEMINI 3 trail, in which active $\mathrm{CD}$ patients who previously failed other treatments were treated with either VDZ or placebo. Two cases of serious infections were noted in VDZ patients (anal abscess and urinary tract infection), neither of which led to treatment interruption (242).

The expression of the $\alpha \mathrm{E} \beta 7$ integrin is elevated in active UC and CD (243). There is an interaction between the $\alpha E \beta 7$ integrin and E-cadherin that 
guides $\mathrm{T}$ cells to the intestinal mucosa and promotes the binding to their ligands, mucosal vascular addressin cell adhesion molecule-1 (MAdCAM-1) and E-cadherin. MAdCAM-1 expression is increased in patients with UC and CD. ETZ is a humanized IgG1 monoclonal antibody which targets the $\beta 7$ subunit of both the $\alpha 4 \beta 7$ and $\alpha E \beta 7$ integrins. ETZ blocks the binding of $\alpha E \beta 7$ to its ligand E-cadherin. Thus, ETZ could affect leukocyte composition within the intestinal mucosa by blocking $\alpha 4 \beta 7$-expressing leukocytes from entering the intestinal mucosa and inhibiting their extravasation through MAdCAM-1-expressing mucosal endothelial venules. Therefore, ETZ inhibits leukocyte homing to the mucosa and avoid the withholding of leukocytes in the intraepithelial space of the intestinal mucosa (244).

A phase II double-blind, randomized, placebocontrolled trial of ETZ in patients with moderate to severe UC showed its efficacy in achieving clinical remission after 10 weeks of therapy (245). In this trial, patients who were non responders to anti-TNF therapy were assigned to receive one of two doses of subcutaneous ETZ or placebo. Clinical response and remission in patients treated with ETZ at either the lower dose $(100 \mathrm{mg})$ or the higher dose (300 $\mathrm{mg}$ ) were significant higher compared to patients receiving placebo after 10 weeks of therapy. Furthermore, biomarker analysis revealed that in treated patients, $\beta 7$ receptors were fully occupied in the peripheral blood and in the colonic tissue. No serious opportunistic infections were reported (245). Furthermore, no PML was observed in a small sample of moderate to severe UC patients treated with ETZ elsewhere (246). A phase III, double blind, placebo-controlled, multicenter study is ongoing, investigating the efficacy and safety of ETZ for the induction and maintenance of remission in patients with moderately to severely active UC who are refractory to or intolerant of TNF inhibitors (http://www.clinicaltrials.gov/ct2/show/NCT02100 696?term $=$ rhuMAb+Beta7\&rank=9).

Approximately 1.4 million persons in the US and 2.2 million persons in Europe have IBD. Variation in presentation and disease course suggests that environmental factors significantly modify the development of $\mathrm{CD}$ and UC, which further excludes the homogene therapy in IBD and vote for personalized approach. Moreover, multiple factors may influence the pharmacokinetics of antiTNF agents and integrin antagonists, such as antigen load, albumin, immunogenicity, concomitant immunosuppressive use, immunocompetent or immunosuppressed status of the individual patient, as well as previous infections. In their 2012 review on TNF antagonist, Ordás et al. suggested the need of therapeutic monitoring of these agents in order to allow rational dose selection and treatment optimization in individual patients during both the induction and maintenance phases of treatment, resulting in greater efficacy (247).

\section{CONCLUSION}

Biological therapies are target-specific and often more efficacious than the traditional immunosuppressive therapeutics used in IBD. IBD is a lifelong, chronic disorder associated with significant morbidity. While anti-TNF $\alpha$ agents have dramatically improved the symptoms and long-term outcomes for many patients with UC and Crohn's disease. However, side effects are common and rates of primary and secondary nonresponse are high. As such pharmacologic agents aimed at other targets are much needed for patients with moderateto-severe disease. The aim of this review was to present an integrative approach that bridges preclinical and clinical research looking at different aspects of monitoring biological therapies in clinical and laboratory settings. De novo infections and reactivation of latent infectious agents are complex processes, and represent an increasingly relevant clinical health problem. With the use of biological therapies in IBD, a disease in which the microbiome is involved, reactivation of latent bacterial and viral infections may occur, and this can change the immune and biological balance interplaying with internal and external triggers. In particular, there is increasing awareness regarding latent virus reactivation. This occurs when a latent virus is reactivated into its active replicative phase as a result of an internal or external trigger, such as immunosuppression.

However, to attribute the risk of viral reactivation to biological therapy alone is not plausible because the underlying malignant or autoimmune condition could also be a contributing factor. This is also the case considering viral reactivation to biological therapy in RA and psoriatic arthritis. There is well documented evidence regarding the reactivation of viruses such 
as HBV, HHV-6 and CMV with non-biological drugs. Long-term data are lacking; such data are essential to guide risk stratification and chemoprophylaxis. Universally accepted viral screening guidelines prior to use of immunosuppression are lacking. As an example, HBV screening prior to commencing immunosuppression, but this action has not translated into universally accepted guidelines. Some of the other relevant viruses involved include $\mathrm{CMV}$ and HCV. Providers and specialty resources are required including gastroenterology, radiology, surgery, pharmacy and laboratory services. We suggest that the clinician should work with the laboratory specialists for a successful therapeutic intervention. Screening procedures for relevant viral and bacterial infections are necessary prior to beginning biological therapy. Moreover, continuously monitoring the levels of TNF- $\alpha$ in patients undergoing anti-TNF therapies, as well as the levels of integrins and cadherin in patients undergoing anti-integrin therapies, will ensure a balance of immune reaction in the clinical setting even prior to starting immunosuppression in IBD. These continuously evolving areas of science, medicine and biopharmaceuticals are becoming increasingly important for clinicians. The focus should be on molecular mechanisms of biological therapies directed towards IBD and how the use of the therapies impacts the immune system. We strongly encourage the collaborations of health professionals with different interests in clinical efficacy, therapeutic drug monitoring and clinical toxicology. The main concern should be pharmacovigillance. Therefore, monitoring biomarkers and infectious diseases should be the aim not only in clinical trials but also in daily practice. Long-term outcomes of latent viral reactivation with different classes of biological therapy are essential to help clinical decisions and patient counseling, with informed consent of the individual regarding possible latent viral reactivation and bacterial infections being part of it. This strategy would allow a personalized approach to therapy that should be more effective and safer. Therapeutic monitoring in patients with IBD under TNF and integrin antagonist treatment has the potential for improving patient safety and important cost utility of therapy.

\section{ACKNOWLEDGMENTS}

In Vitro Drug Safety and Biotechnology grant and Mahaffy innovative grant - Sunnybrook Health Science Centre, Toronto, Canada supported the work. All authors have read the journal's policy on conflicts of interest and have none to declare. Also, all authors have read the journal's policy on authorship and there are no conflicts of interest. 
Table 1. TB in anti-TNF-treated IBD Patients

\begin{tabular}{|c|c|c|c|c|c|}
\hline Ref & Patients Demographics & Drug & $\begin{array}{l}\text { Co-medication/ } \\
\text { co-infections }\end{array}$ & $\begin{array}{l}\text { Type Infection; Method } \\
\text { of Detection }\end{array}$ & Outcome \\
\hline 70 & $\begin{array}{l}53 \mathrm{M}-\mathrm{CD} \\
\text { Spain } \\
\text { Screening not performed }\end{array}$ & IFX (2 infusions) & Steroid dependent & $\begin{array}{l}\text { M. tuberculosis } \\
\text { Culture }\end{array}$ & $\begin{array}{l}\text { Anti-TB treatment } \\
\text { Resolution of symptoms }\end{array}$ \\
\hline 71 & $\begin{array}{l}24 \text { M- CD } \\
\text { Netherlands } \\
\text { TST negative } \\
\text { Normal chest X-ray }\end{array}$ & $\begin{array}{l}\text { IFX ( } 4 \text { doses over } 10 \\
\text { months) }\end{array}$ & Prednisone & $\begin{array}{l}\text { De novo M. tuberculosis } \\
\text { infection } \\
\text { Culture }\end{array}$ & $\begin{array}{l}\text { Isoniazid, rifampin and ethambutol, } \\
\text { pyrazinamide } \\
\text { Paradoxical reaction } \\
\text { Partially recovered after } 1 \text { year }\end{array}$ \\
\hline 72 & $\begin{array}{l}28 \mathrm{M}-\mathrm{CD} \\
\text { Scotland } \\
\text { IFN- } \gamma \text { release negative } \\
\text { Normal chest X-ray }\end{array}$ & IFX for 2 months & Azathioprine & $\begin{array}{l}\text { Pulmonary TB } \\
\text { Acid, alcohol fast bacilli } \\
\text { Culture }\end{array}$ & $\begin{array}{l}\text { Standard quadruple anti-TB } \\
\text { chemotherapy } \\
\text { Immune reconstitution inflammatory } \\
\text { syndrome } \\
\text { Resolution of symptoms }\end{array}$ \\
\hline 73 & $\begin{array}{l}47 \mathrm{M} \text { from Pakistan } \\
\text { Indeterminate colitis } \\
\text { Spain } \\
\text { TST negative } \\
\text { Normal chest X-ray }\end{array}$ & IFX (3 infusions) & $\begin{array}{l}\text { Azathioprine } \\
\text { HIV with normal CD } 4^{+} \mathrm{T} \text { cell } \\
\text { counts } 368 / \mathrm{mm}^{3} \text { and viral load } \\
3600 / \mathrm{mL} \\
\text { efavirenz and tenofovir }\end{array}$ & $\begin{array}{l}\text { Pulmonary and thoracic } \\
\text { TB } \\
\text { Lymph node fine-needle } \\
\text { puncture }\end{array}$ & $\begin{array}{l}\text { Tuberculostatic drugs } \\
\text { Eventual recovery following bacterial } \\
\text { pulmonary abscess and herpetic } \\
\text { stomatitis }\end{array}$ \\
\hline 74 & $\begin{array}{l}68 \text { F IBD } \\
\text { France } \\
\text { TST negative } \\
\text { Normal chest X-ray }\end{array}$ & ADM for 2 months & $\begin{array}{l}\text { Long-term glucocorticoids } \\
\text { Untreated primary TB, initially } \\
\text { unreported }\end{array}$ & $\begin{array}{l}\text { Tuberculoid granulomas } \\
\text { in liver and spleen } \\
\text { Culture }\end{array}$ & $\begin{array}{l}\text { Quadruple TB therapy } \\
\text { Paradoxical reaction } \\
\text { Resolution of symptoms }\end{array}$ \\
\hline 75 & $\begin{array}{l}52 \mathrm{M}-\mathrm{CD} \\
\text { USA } \\
\text { QFT-G and TST positive; } \\
\text { Normal chest X-ray }\end{array}$ & $\begin{array}{l}\text { IFX for } 4 \text { months } \\
\text { ADM for } 1 \text { month }\end{array}$ & $\begin{array}{l}\text { Isoniazid, pyridoxine treatment; } \\
\text { prophylaxis } 11 \text { months; } \\
\text { Prednisone }\end{array}$ & $\begin{array}{l}\text { Pulmonary TB with liver } \\
\text { and spleen lesions; } \\
\text { Culture }\end{array}$ & $\begin{array}{l}\text { Isoniazid, rifampin, ethambutol and } \\
\text { pyrazinamide } \\
\text { Resolution of symptoms }\end{array}$ \\
\hline 76 & $\begin{array}{l}38 \mathrm{M}-\mathrm{CD} \\
\text { Korea } \\
\text { TST positive } \\
\text { Normal chest X-ray }\end{array}$ & IFX (3 infusions) & Methylprednisolone & $\begin{array}{l}\text { Miliary TB; nodular } \\
\text { spleen lesions; TST } \\
\text { positive; Acid fast bacilli } \\
\text { Culture, Genetic } \\
\text { detection }\end{array}$ & $\begin{array}{l}\text { Isoniazid, rifampin, pyrazinamide } \\
\text { and ethambutol } \\
\text { Paradoxical reaction } \\
\text { Resolution of symptoms }\end{array}$ \\
\hline 77 & $\begin{array}{l}53 \text { F- CD } \\
\text { Serbia } \\
\text { TST negative } \\
\text { Normal chest X-ray }\end{array}$ & $\begin{array}{l}\text { IFX ( } 3 \text { infusions over } \\
3 \text { months) }\end{array}$ & Azathioprine & $\begin{array}{l}\text { Miliary TB } \\
\text { Culture }\end{array}$ & $\begin{array}{l}\text { Isoniasid, rifampicine, streptomycine, } \\
\text { pyrazinamide and ethambutol } \\
\text { Resolution of symptoms }\end{array}$ \\
\hline
\end{tabular}


Table 1 (Contitued). TB in anti-TNF-treated IBD Patients

\begin{tabular}{|c|c|c|c|c|c|}
\hline Ref & $\begin{array}{l}\text { Patients } \\
\text { Demographics }\end{array}$ & Drug & $\begin{array}{l}\text { Co-medication/ } \\
\text { co-infections }\end{array}$ & $\begin{array}{l}\text { Type Infection; Method } \\
\text { of Detection }\end{array}$ & Outcome \\
\hline 78 & $\begin{array}{l}40 \text { M- CD } \\
\text { West Europe } \\
\text { TST negative } \\
\text { Normal chest X-ray }\end{array}$ & $\begin{array}{l}\text { IFX ( } 2 \text { infusions over } 3 \\
\text { weeks) }\end{array}$ & $\begin{array}{l}\text { Corticosteroids } \\
\text { Aziathioprine }\end{array}$ & $\begin{array}{l}\text { Cerebral tuberculomas, } \\
\text { lung, mediastinal and } \\
\text { abdominal nodes, skin } \\
\text { involvement } \\
\text { Genetic detection, } \\
\text { culture } \\
\text { Miliary TB: liver, bone } \\
\text { marrow and mediastinal } \\
\text { extension } \\
\text { Genetic detection, } \\
\text { culture }\end{array}$ & $\begin{array}{l}\text { Anti-TB treatment } \\
\text { Resolution of symptoms }\end{array}$ \\
\hline 79 & $\begin{array}{l}55 \text { M- CD } \\
\text { Spain } \\
\text { TST positive } \\
\text { Normal chest X-ray }\end{array}$ & $\mathrm{ADM}$ for 2 months & Azathioprine & $\begin{array}{l}\text { Disseminated miliary } \\
\text { TB, monoarthritis TB } \\
\text { TST positive } \\
\text { Culture }\end{array}$ & $\begin{array}{l}\text { Tuberculostatic therapy } \\
\text { Resolution of symptoms }\end{array}$ \\
\hline 80 & $\begin{array}{l}64 \mathrm{M}-\mathrm{CD} \\
\text { Germany } \\
\text { TST negative }\end{array}$ & $\begin{array}{l}\text { IFX ( } 7 \text { infusions over } 5 \\
\text { months) }\end{array}$ & Azathioprine & $\begin{array}{l}\text { Peritoneal TB } \\
\text { QFT-G } \\
\text { Genetic detection } \\
\text { Culture }\end{array}$ & $\begin{array}{l}\text { Isoniazid, rifampicin, pyrazinamide and } \\
\text { ethambutol Improvement of patient condition }\end{array}$ \\
\hline 81 & $\begin{array}{l}21 \mathrm{M}-\mathrm{CD} \\
\text { Spain } \\
\text { TST unknown } \\
\text { Normal chest X-ray }\end{array}$ & $\begin{array}{l}\text { IFX } \\
\text { Symptoms started } 4 \\
\text { weeks after first IFX } \\
\text { infusion }\end{array}$ & Not specified & $\begin{array}{l}\text { Anal TB } \\
\text { Acid-fast bacilli } \\
\text { Culture }\end{array}$ & $\begin{array}{l}\text { Isoniazid, rifampin and pyrazinamide } \\
\text { Paradoxical reaction } \\
\text { Recovered after } 9 \text { months of non-steroidal anti- } \\
\text { inflammatory drugs }\end{array}$ \\
\hline
\end{tabular}


Table 2. Bacterial Infections in anti-TNF-treated IBD Patients

\begin{tabular}{|c|c|c|c|c|c|}
\hline Ref & Patient Demographics & Drug & $\begin{array}{l}\text { Co-medication/ } \\
\text { co-infections }\end{array}$ & $\begin{array}{l}\text { Type of Infection and } \\
\text { Method of Detection }\end{array}$ & Outcome \\
\hline 85 & $\begin{array}{l}60 \mathrm{M} \\
\text { Crohn's ileocolitis } \\
\text { USA }\end{array}$ & IFX for 6 months & $\mathrm{n} / \mathrm{a}$ & $\begin{array}{l}\text { M. marinum } \\
\text { Culture }\end{array}$ & $\begin{array}{l}\text { Minocycline } \\
\text { Resolution of symptoms }\end{array}$ \\
\hline 85 & $\begin{array}{l}33 \text { F CD } \\
\text { USA }\end{array}$ & IFX (2 infusions) & $\mathrm{n} / \mathrm{a}$ & $\begin{array}{l}\text { M. marinum } \\
\text { Acid fast bacilli, Culture }\end{array}$ & $\begin{array}{l}\text { Rifampin and doxycycline } \\
\text { Resolution of symptoms }\end{array}$ \\
\hline 86 & $\begin{array}{l}50 \mathrm{M}-\mathrm{CD} \\
\text { USA }\end{array}$ & IFX (4 infusions) & $\begin{array}{l}\text { Oral immuno- } \\
\text { suppressants }\end{array}$ & $\begin{array}{l}\text { Cutaneous } M . \text { marinum } \\
\text { infection } \\
\text { Culture }\end{array}$ & $\begin{array}{l}\text { Minocycline, ethambutol and clarithromycin } \\
\text { Resolution of symptoms }\end{array}$ \\
\hline 87 & $\begin{array}{l}40 \mathrm{M}-\mathrm{CD} \\
\text { Austria } \\
\text { TST negative } \\
\text { Normal chest X-ray }\end{array}$ & ADM for 3 months & $\mathrm{n} / \mathrm{a}$ & $\begin{array}{l}\text { M. marinum } \\
\text { Acid fast bacilli } \\
\text { Culture; TST positive } \\
\text { IFN- } \gamma \text { release positive }\end{array}$ & $\begin{array}{l}\text { Rifampicin and ethambutol } \\
\text { Resolution of symptoms }\end{array}$ \\
\hline 88 & $\begin{array}{l}37 \mathrm{~F}-\mathrm{CD} \\
\text { Ireland }\end{array}$ & IFX over 2 years & $\begin{array}{l}\text { Azathioprine, } \\
\text { mesalazine }\end{array}$ & $\begin{array}{l}\text { M. marinum; } \\
\text { Culture } \\
\text { Genetic detection }\end{array}$ & $\begin{array}{l}\text { Minocycline, doxycycline and clarithromycin } \\
\text { Resolution of symptoms }\end{array}$ \\
\hline 89 & $\begin{array}{l}63 \mathrm{M}-\mathrm{CD} \\
\text { France }\end{array}$ & IFX over 3 years & $\mathrm{n} / \mathrm{a}$ & $\begin{array}{l}\text { M. marinum } \\
\text { Culture }\end{array}$ & $\begin{array}{l}\text { Minocycline } \\
\text { Resolution of symptoms }\end{array}$ \\
\hline 90 & $\begin{array}{l}32 \text { M- CD } \\
\text { Spain } \\
\text { TST negative } \\
\text { Normal chest X-ray }\end{array}$ & IFX for 6 weeks & $\begin{array}{l}\text { Prednisone, } \\
\text { mesalazine and } \\
\text { metronidazole }\end{array}$ & $\begin{array}{l}\text { M. marinum } \\
\text { Acid fast bacilli } \\
\text { Culture } \\
\text { Genetic detection }\end{array}$ & $\begin{array}{l}\text { Ethambutol and rifampicin } \\
\text { Clarithromycin and prednisone added } \\
\text { subsequently } \\
\text { Resolution of symptoms }\end{array}$ \\
\hline 91 & $\begin{array}{l}36 \mathrm{~F}-\mathrm{CD} \\
\mathrm{USA}\end{array}$ & IFX for 2 years & $\begin{array}{l}\text { Anti-depression } \\
\text { medication }\end{array}$ & $\begin{array}{l}\text { M. avium complex } \\
\text { Acid fast bacilli } \\
\text { Culture }\end{array}$ & $\begin{array}{l}\text { Rifampin, ethambutol, ciprofloxacin and } \\
\text { azithromycin } \\
\text { Immune reconstitution inflammatory } \\
\text { syndrome; Resolution of symptoms }\end{array}$ \\
\hline 92 & $\begin{array}{l}11 \mathrm{~F}-\mathrm{CD} \\
\text { TST negative } \\
\text { Normal chest X-ray }\end{array}$ & $\begin{array}{l}\text { IFX for } 4 \text { months } \\
\text { ADM for } 5 \text { months }\end{array}$ & $\begin{array}{l}\text { Mesalazine, } \\
\text { corticosteroids and 6- } \\
\text { mercaptopurine }\end{array}$ & $\begin{array}{l}\text { M. avium complex } \\
\text { QFT-G positive } \\
\text { Culture }\end{array}$ & $\begin{array}{l}\text { Ethambutol, clarithromycin and rifampin } \\
\text { Resolution of symptoms }\end{array}$ \\
\hline 94 & $\begin{array}{l}67 \mathrm{M}-\mathrm{CD} \\
\mathrm{USA}\end{array}$ & IFX (3 infusions) & $\begin{array}{l}\text { Prednisone, } \\
\text { azothioprine, } \\
\text { mesalazine }\end{array}$ & $\begin{array}{l}\text { L. monocytogenes } \\
\text { Blood culture }\end{array}$ & $\begin{array}{l}\text { Amoxicillin and clavulanic acid Resolution of } \\
\text { symptoms }\end{array}$ \\
\hline 95 & $\begin{array}{l}48 \mathrm{M}-\mathrm{CD} \\
\text { Israel }\end{array}$ & IFX (1 infusion) & $\mathrm{n} / \mathrm{a}$ & $\begin{array}{l}\text { L. monocytogenes } \\
\text { Blood culture }\end{array}$ & $\begin{array}{l}\text { Ampicillin, gentamycin and metronidazole } \\
\text { Resolution of symptoms }\end{array}$ \\
\hline 96 & $\begin{array}{l}68 \mathrm{M}-\mathrm{CD} \\
\text { Spain }\end{array}$ & IFX (2 infusions) & $\begin{array}{l}\text { Prednisone and } \\
\text { azathioprine }\end{array}$ & $\begin{array}{l}\text { L. monocytogenes } \\
\text { Blood culture }\end{array}$ & $\begin{array}{l}\text { Amoxicillin and clavulanic acid } \\
\text { Resolution of symptoms } \\
\qquad \text { Conttinue................ }\end{array}$ \\
\hline
\end{tabular}


Table 2 (Continued). Bacterial Infections in anti-TNF-treated IBD Patients

\begin{tabular}{|c|c|c|c|c|c|}
\hline$\overline{\operatorname{Ref}}$ & Patient Demographics & Drug & $\begin{array}{l}\text { Co-medication/ } \\
\text { co-infections }\end{array}$ & $\begin{array}{l}\text { Type of Infection and } \\
\text { Method of Detection }\end{array}$ & Outcome \\
\hline 97 & $\begin{array}{l}37 \mathrm{M}-\mathrm{CD} \\
\text { Canada }\end{array}$ & IFX (2 infusions) & $\begin{array}{l}\text { Azathioprine and } \\
\text { corticosteroids }\end{array}$ & $\begin{array}{l}\text { L. monocytogenes } \\
\text { CSF and blood culture }\end{array}$ & $\begin{array}{l}\text { Ampicillin, gentamicin and trimethoprim- } \\
\text { sulfamethoxazole } \\
\text { Resolution of symptoms }\end{array}$ \\
\hline 98 & $\begin{array}{l}50 \text { F- CD } \\
\text { Spain }\end{array}$ & IFX (3 infusions) & Azathioprine & $\begin{array}{l}\text { L. monocytogenes } \\
\text { Blood and CSF culture }\end{array}$ & $\begin{array}{l}\text { Ampicillin and gentamycin } \\
\text { Resolution of symptoms }\end{array}$ \\
\hline 99 & $\begin{array}{l}17 \mathrm{~F}-\mathrm{CD} \\
\mathrm{USA}\end{array}$ & IFX (1 infusion) & $\begin{array}{l}\text { 6-mercaptopurine, } \\
\text { mesalazine, } \\
\text { prednisone, } \\
\text { methylprednisolone }\end{array}$ & $\begin{array}{l}\text { L. monocytogenes } \\
\text { Blood culture } \\
\text { Meningitis }\end{array}$ & $\begin{array}{l}\text { Ampicillin and trimethoprim- } \\
\text { sulfamethoxazole } \\
\text { Resolution of symptoms }\end{array}$ \\
\hline 100 & $\begin{array}{l}34 \mathrm{M}-\mathrm{CD} \\
\text { France }\end{array}$ & IFX (3 infusions) & $\begin{array}{l}\text { Mesalazine, } \\
\text { azathioprine }\end{array}$ & $\begin{array}{l}\text { L. monocytogenes } \\
\text { Blood culture, Meningitis }\end{array}$ & $\begin{array}{l}\text { Ampicillin and gentamycin } \\
\text { Partial resolution of symptoms }\end{array}$ \\
\hline 101 & $\begin{array}{l}19 \text { M- CD } \\
\text { Spain }\end{array}$ & ADM over 3 months & Azathioprine & $\begin{array}{l}\text { L. monocytogenes } \\
\text { Blood culture } \\
\text { Meningitis }\end{array}$ & $\begin{array}{l}\text { Ampicillin and gentamycin } \\
\text { Resolution of symptoms }\end{array}$ \\
\hline 102 & $\begin{array}{l}17 \mathrm{M}-\mathrm{UC} \\
\text { USA }\end{array}$ & IFX (1 infusion) & $\begin{array}{l}\text { Mesalazine, } \\
\text { prednisone }\end{array}$ & $\begin{array}{l}\text { L. monocytogenes } \\
\text { CSF and blood culture } \\
\text { Meningitis }\end{array}$ & $\begin{array}{l}\text { Meropenem, gentamicin } \\
\text { Resolution of symptoms }\end{array}$ \\
\hline 103 & $\begin{array}{l}51 \text { F- UC } \\
\text { Portugal }\end{array}$ & $\begin{array}{l}\text { IFX ( } 2 \text { infusions over } \\
5 \text { weeks) }\end{array}$ & Steroids & $\begin{array}{l}\text { L. monocytogenes } \\
\text { Blood culture } \\
\text { Purulent meningitis }\end{array}$ & $\begin{array}{l}\text { Ampicillin } \\
\text { Resolution of symptoms }\end{array}$ \\
\hline & $\begin{array}{l}69 \text { M- UC } \\
\text { Portugal }\end{array}$ & & $\begin{array}{l}\text { Prednisolone } \\
\text { Emtricitabine, } \\
\text { tenofovir, efavirenz } \\
\text { for HIV }\end{array}$ & $\begin{array}{l}\text { L. monocytogenes } \\
\text { Blood culture } \\
\text { Genetic detection }\end{array}$ & $\begin{array}{l}\text { Isoniazid, } \\
\text { Ampicillin, gentamicin } \\
\text { Resolution of symptoms }\end{array}$ \\
\hline 104 & $\begin{array}{l}64 \text { F- CD } \\
\text { Canada }\end{array}$ & IFX (1 infusion) & $\begin{array}{l}\text { Prednisone, } \\
\text { mercaptopurine, } \\
\text { glyburide }\end{array}$ & $\begin{array}{l}\text { L. monocytogenes } \\
\text { Blood culture }\end{array}$ & $\begin{array}{l}\text { Treatment not specified } \\
\text { Resolution of symptoms }\end{array}$ \\
\hline & $\begin{array}{l}39 \mathrm{~F}-\mathrm{CD} \\
\text { Sweden }\end{array}$ & IFX (3 infusions) & $\begin{array}{l}\text { Prednisolone, } \\
\text { mercaptopurine, } \\
\text { mesalazine }\end{array}$ & $\begin{array}{l}\text { L. monocytogenes } \\
\text { Blood culture } \\
\text { Meningitis }\end{array}$ & $\begin{array}{l}\text { Treatment not specified } \\
\text { Partial resolution of symptoms }\end{array}$ \\
\hline & $\begin{array}{l}20 \mathrm{M}-\mathrm{CD} \\
\text { Italy }\end{array}$ & IFX (1 infusion) & $\begin{array}{l}\text { Methylpredniso-lone, } \\
\text { azathioprine, } \\
\text { mesalazine, } \\
\text { metronidazole }\end{array}$ & $\begin{array}{l}\text { L. monocytogenes } \\
\text { Meningitis }\end{array}$ & $\begin{array}{l}\text { Treatment not specified } \\
\text { Death } \\
\qquad \text { Continue..... }\end{array}$ \\
\hline
\end{tabular}


Table 2 (Continued). Bacterial Infections in anti-TNF-treated IBD Patients

\begin{tabular}{|c|c|c|c|c|c|}
\hline$\overline{\text { Ref }}$ & Patient Demographics & Drug & $\begin{array}{l}\text { Co-medication/ } \\
\text { co-infections }\end{array}$ & $\begin{array}{l}\text { Type of Infection and } \\
\text { Method of Detection }\end{array}$ & Outcome \\
\hline 105 & $\begin{array}{l}35 \text { F- CD } \\
\text { Spain }\end{array}$ & IFX (2 infusions) & Azathioprine & $\begin{array}{l}\text { L. monocytogenes } \\
\text { CSF culture } \\
\text { Meningitis }\end{array}$ & $\begin{array}{l}\text { Ampicillin and gentamycin } \\
\text { Resolution of symptoms }\end{array}$ \\
\hline 106 & $\begin{array}{l}50 \text { F- CD } \\
\text { Hungary }\end{array}$ & IFX (episodic) & Methyl-prednisolone & $\begin{array}{l}\text { L. monocytogenes } \\
\text { CSF culture } \\
\text { Meningitis }\end{array}$ & $\begin{array}{l}\text { Ampicillin and amikacin } \\
\text { Resolution of symptoms }\end{array}$ \\
\hline 111 & $\begin{array}{l}27 \mathrm{~F}-\mathrm{CD} \\
\text { France }\end{array}$ & IFX (1 infusion) & $\begin{array}{l}\text { Azathioprine and } \\
\text { prednisone }\end{array}$ & $\begin{array}{l}\text { L. pneumophila } \\
\text { Urine antigen detection } \\
\text { Culture }\end{array}$ & $\begin{array}{l}\text { Rifampicin } \\
\text { Resolution of symptoms }\end{array}$ \\
\hline 112 & $\begin{array}{l}71 \mathrm{M}-\mathrm{UC} \\
\text { Italy }\end{array}$ & IFX (1 infusion) & Mesalazine & $\begin{array}{l}\text { L. pneumophila serotype } \\
1 \\
\text { Genetic detection }\end{array}$ & $\begin{array}{l}\text { Antibiotics } \\
\text { Death due to septic shock }\end{array}$ \\
\hline 113 & $\begin{array}{l}58 \mathrm{M}-\mathrm{CD} \\
\text { Germany }\end{array}$ & IFX (3 infusions) & Azathioprine & $\begin{array}{l}\text { L. pneumophila serotype } \\
1 \\
\text { Urine antigen detection } \\
\text { Genetic detection }\end{array}$ & $\begin{array}{l}\text { Piperacillin-tazobactam and moxifloxacine } \\
\text { Resolution of symptoms }\end{array}$ \\
\hline 114 & $\begin{array}{l}26 \mathrm{M}-\mathrm{CD} \\
\text { Canada }\end{array}$ & IFX (1 infusion) & $\begin{array}{l}\text { Morphine } \\
\text { 6-mercaptopurine } \\
\text { Smoking history }\end{array}$ & $\begin{array}{l}\text { L. pneumophila serotype } \\
1 \\
\text { Urine antigen detection }\end{array}$ & $\begin{array}{l}\text { Piperacillin-tazobactam, vancomycin, } \\
\text { azithromycin, caspofungin, followed by } \\
\text { azithromycin } \\
\text { Partial resolution of symptoms }\end{array}$ \\
\hline & $\begin{array}{l}59 \mathrm{M}-\mathrm{CD} \\
\text { Canada }\end{array}$ & IFX (1 infusion) & $\begin{array}{l}\text { Methyl-prednisolone } \\
\text { Smoking history }\end{array}$ & $\begin{array}{l}\text { L. pneumophila serotype, } \\
\text { urine antigen detection } \\
\text { CMV, } \\
\text { P. aeruginosa } \\
\text { Enterococcus species } \\
\text { Culture }\end{array}$ & $\begin{array}{l}\text { Piperacillin-tazobactam, ciprofloxacin, } \\
\text { azithromycin } \\
\text { Catheter-related candidemia } \\
\text { Death due to unrelated causes }\end{array}$ \\
\hline 115 & $\begin{array}{l}26 \text { F- CD } \\
\text { Netherlands }\end{array}$ & $\begin{array}{l}\text { IFX (10 infusions over } \\
17 \text { months) }\end{array}$ & $\mathrm{n} / \mathrm{a}$ & $\begin{array}{l}\text { L. pneumophila serotype } \\
1 \\
\text { Urine and serum antigen } \\
\text { detection }\end{array}$ & Erythromycin Resolution of symptoms \\
\hline 117 & $\begin{array}{l}40 \mathrm{~F}-\mathrm{CD} \\
\text { Germany }\end{array}$ & IFX (6 infusions) & Mesalazine & $\begin{array}{l}\text { S. aureus } \\
\text { Culture }\end{array}$ & $\begin{array}{l}\text { Moxifloxacin, imipenem, vancomycin and } \\
\text { clarithromycin } \\
\text { Death due to respiratory failure }\end{array}$ \\
\hline
\end{tabular}

Contniue. 
Table 2 (Continued). Bacterial Infections in anti-TNF-treated IBD Patients

\begin{tabular}{|c|c|c|c|c|c|}
\hline Ref & Patient Demographics & Drug & $\begin{array}{l}\text { Co-medication/ } \\
\text { co-infections }\end{array}$ & $\begin{array}{l}\text { Type of Infection and } \\
\text { Method of Detection }\end{array}$ & Outcome \\
\hline 118 & $\begin{array}{l}29 \mathrm{M}-\mathrm{CD} \\
\text { USA }\end{array}$ & IFX & $\mathrm{n} / \mathrm{a}$ & $\begin{array}{l}\text { Methicillin-resistant } S \text {. } \\
\text { aureus; Culture } \\
\text { Acid fast bacilli; CT- } \\
\text { guided needle aspirate }\end{array}$ & $\begin{array}{l}\text { Vancomycin, rifampin and trimethoprim- } \\
\text { sulfamethoxazole } \\
\text { Four-drug anti-TB treatment } \\
\text { Resolution of symptoms }\end{array}$ \\
\hline 119 & $\begin{array}{l}63 \text { F- UC } \\
\text { Portugal }\end{array}$ & IFX (3 infusions) & Prednisolone & $\begin{array}{l}\text { S. aureus } \\
\text { Culture }\end{array}$ & $\begin{array}{l}\text { Ciprofloxacin and vancomycin } \\
\text { Resolution of symptoms }\end{array}$ \\
\hline 120 & $\begin{array}{l}32 \text { Caucasian M- CD } \\
\text { Japan }\end{array}$ & IFX over 2 years & Prednisolone & $\begin{array}{l}\text { S. aureus } \\
\text { Culture }\end{array}$ & $\begin{array}{l}\text { Intravenous antibiotics } \\
\text { Partial resolution of symptoms }\end{array}$ \\
\hline 121 & $\begin{array}{l}31 \mathrm{M}-\mathrm{CD} \\
\text { Japan }\end{array}$ & IFX (9 infusions) & $\mathrm{n} / \mathrm{a}$ & $\begin{array}{l}\text { E. coli; Methicillin- } \\
\text { resistant S. aureus } \\
\text { Culture } \\
\text { Screening agar }\end{array}$ & $\begin{array}{l}\text { Vancomycin, teicoplanin; Surgery, then } \\
\text { teicoplanin, meropenem; Fluconazole for } \\
\text { catheter-related C. parapsilosis } \\
\text { Resolution of symptoms }\end{array}$ \\
\hline 122 & $\begin{array}{l}51 \mathrm{~F}-\mathrm{CD} \\
\mathrm{USA}\end{array}$ & CZP for 6 months & $\mathrm{n} / \mathrm{a}$ & $\begin{array}{l}\text { N. meningitidis group } \\
\text { C/W135; CSF antigen } \\
\text { detection }\end{array}$ & $\begin{array}{l}\text { Ceftriaxone } \\
\text { Resolution of symptoms }\end{array}$ \\
\hline 123 & $\begin{array}{l}45 \mathrm{M}-\mathrm{CD} \\
\text { Canada }\end{array}$ & IFX (5 infusions) & $\begin{array}{l}\text { Budesonide, } \\
\text { mesalazine, } \\
\text { ciprofloxacin and } \\
\text { metronidazole }\end{array}$ & $\begin{array}{l}\text { Nocardia species } \\
\text { Genetic detection } \\
\text { S. aureus and } M . \text { marinum } \\
\text { infection suspected }\end{array}$ & $\begin{array}{l}\text { Cloxacillin, then minocycline, then } \\
\text { trimethoprim-sulfamethoxazole } \\
\text { Resolution of symptoms }\end{array}$ \\
\hline 124 & $\begin{array}{l}61 \mathrm{M}-\mathrm{CD} \\
\text { USA }\end{array}$ & IFX over 1.5 years & $\mathrm{n} / \mathrm{a}$ & $\begin{array}{l}\text { Nocardia species } \\
\text { Skin biopsy }\end{array}$ & $\begin{array}{l}\text { Trimethoprim-sulfamethoxazole } \\
\text { Resolution of symptoms }\end{array}$ \\
\hline 125 & $\begin{array}{l}53 \text { F CD } \\
\text { Spain }\end{array}$ & IFX (3 infusions) & $\begin{array}{l}\text { Prednisone, } \\
\text { azathioprine }\end{array}$ & $\begin{array}{l}\text { N. cyriacigeorgica } \\
\text { Culture } \\
\text { Genetic detection }\end{array}$ & $\begin{array}{l}\text { Levofloxacin, meropenem, trimethoprim- } \\
\text { sulfamethoxazole, amikacin, imipenem } \\
\text { Resolution of symptoms }\end{array}$ \\
\hline 126 & $\begin{array}{l}81 \mathrm{M}-\mathrm{CD} \\
\text { USA }\end{array}$ & IFX over 6 months & $\begin{array}{l}\text { Mesalazine, 6- } \\
\text { mercaptopurine }\end{array}$ & $\begin{array}{l}N . \text { pneumonia } \\
\text { Culture }\end{array}$ & $\begin{array}{l}\text { Trimethoprim-sulfamethoxazole } \\
\text { Resolution of symptoms }\end{array}$ \\
\hline 127 & $\begin{array}{l}20 \mathrm{M}-\mathrm{UC} \\
\text { Spain }\end{array}$ & IFX & $\begin{array}{l}\text { Azathioprine, } \\
\text { prednisone }\end{array}$ & $\begin{array}{l}P . \text { aeruginosa cavitary } \\
\text { pneumonia }\end{array}$ & $\begin{array}{l}\text { Treatment not specified } \\
\text { Resolution of symptoms }\end{array}$ \\
\hline
\end{tabular}

Continue .............. 
Table 2 (Continued). Bacterial Infections in anti-TNF-treated IBD Patients

\begin{tabular}{|c|c|c|c|c|c|c|}
\hline \multicolumn{2}{|c|}{ Patient Demographics } & \multirow[t]{2}{*}{ Drug } & \multicolumn{2}{|c|}{$\begin{array}{l}\text { Co-medication/ } \\
\text { co-infections }\end{array}$} & \multicolumn{2}{|l|}{$\begin{array}{l}\text { Type of Infection and } \\
\text { Method of Detection }\end{array}$} \\
\hline 128 & $\begin{array}{l}71 \mathrm{M}-\mathrm{UC} \\
\text { Scotland }\end{array}$ & & IFX (1 infusion) & $\begin{array}{l}\text { Balsalazide, } \\
\text { prednisolone, } \\
\text { azathioprine }\end{array}$ & $\begin{array}{l}\text { P. aeruginosa broncho- } \\
\text { pulmonary pneumonia } \\
\text { Culture }\end{array}$ & $\begin{array}{l}\text { Ischemic heart disease; mild chronic } \\
\text { obstructive pulmonary disease; Inotropes and } \\
\text { broad-spectrum antibiotics } \\
\text { Death from septicemia } \\
\quad \text { Continues .............. }\end{array}$ \\
\hline 129 & $\begin{array}{l}68 \mathrm{M}-\mathrm{CD} \\
\text { USA }\end{array}$ & & IFX over 15 months & $\mathrm{n} / \mathrm{a}$ & $\begin{array}{l}\text { S. enteritidis } \\
\text { Culture }\end{array}$ & $\begin{array}{l}\text { Levofloxacin } \\
\text { Resolution of symptoms }\end{array}$ \\
\hline 130 & $\begin{array}{l}35 \mathrm{M}-\mathrm{CD} \\
\text { Germany }\end{array}$ & & IFX (1 infusion) & Azathioprine & $\begin{array}{l}\text { S. typhimurium } \\
\text { Culture } \\
\text { C. difficile toxin }\end{array}$ & $\begin{array}{l}\text { Piperacilline-sulbactame, ciprofloxacine and } \\
\text { metronidazole } \\
\text { Resolution of symptoms }\end{array}$ \\
\hline 131 & $\begin{array}{l}67 \mathrm{M}-\mathrm{UC} \\
\text { France }\end{array}$ & & IFX over 1 month & $\mathrm{n} / \mathrm{a}$ & $\begin{array}{l}\text { S. enterica } \\
\text { Culture }\end{array}$ & $\begin{array}{l}\text { Ofloxacin, then ciprofloxacin } \\
\text { Resolution of symptoms }\end{array}$ \\
\hline 132 & $\begin{array}{l}31 \mathrm{M}-\mathrm{CD} \\
\text { Germany }\end{array}$ & & IFX & Azathioprine & $\begin{array}{l}\text { S. enterica serovar } \\
\text { Minnesota } \\
\text { Culture }\end{array}$ & $\begin{array}{l}\text { Meropenem and vancomycin, then ceftriaxone } \\
\text { Resolution of symptoms }\end{array}$ \\
\hline
\end{tabular}

Table 3. Fungal Infections in anti-TNF-treated IBD Patients

\begin{tabular}{|c|c|c|c|c|c|}
\hline Ref & $\begin{array}{l}\text { Patient } \\
\text { Demographics }\end{array}$ & Drug & $\begin{array}{l}\text { Co-medication/co- } \\
\text { infections }\end{array}$ & $\begin{array}{l}\text { Type of Infection; Method } \\
\text { of detection }\end{array}$ & Outcome \\
\hline 137 & $\begin{array}{l}51 \mathrm{M}-\mathrm{CD} \\
\text { Netherlands }\end{array}$ & IFX & $\begin{array}{l}\text { Azathioprine, then } \\
\text { methotrexate }\end{array}$ & $\begin{array}{l}\text { Pnneumococcus jirovecii } \\
\text { pneumonia } \\
\text { Staining in broncho- } \\
\text { alveolar lavage }\end{array}$ & $\begin{array}{l}\text { TR-SMX, prednisolone } \\
\text { Resolution of symptoms }\end{array}$ \\
\hline 138 & $\begin{array}{l}29 \mathrm{M}-\mathrm{CD} \\
\text { France }\end{array}$ & IFX (1 infusion) & $\begin{array}{l}\text { Prednisolone, then } \\
\text { azathioprine }\end{array}$ & $\begin{array}{l}P . \text { jirovecii pneumonia } \\
\text { Staining in broncho- } \\
\text { alveolar lavage }\end{array}$ & $\begin{array}{l}\text { TR-SMX, } \\
\text { Resolution of symptoms }\end{array}$ \\
\hline & & & & & Continue . \\
\hline
\end{tabular}


Table 3 (Continued). Fungal Infections in anti-TNF-treated IBD Patients

\begin{tabular}{|c|c|c|c|c|c|}
\hline Ref & $\begin{array}{l}\text { Patient } \\
\text { Demographics }\end{array}$ & Drug & $\begin{array}{l}\text { Co-medication/co- } \\
\text { infections }\end{array}$ & $\begin{array}{l}\text { Type of Infection; Method } \\
\text { of detection }\end{array}$ & Outcome \\
\hline 139 & $\begin{array}{l}19 \mathrm{M}-\mathrm{CD} \\
\mathrm{USA}\end{array}$ & $\begin{array}{l}\text { IFX (14 infusions } \\
\text { over } 21 \text { months) }\end{array}$ & $\begin{array}{l}\text { Prednisone, then } \\
\text { azathioprine }\end{array}$ & $\begin{array}{l}P . \text { jirovecii pneumonia } \\
\text { Staining in bronchoalveolar } \\
\text { lavage; Oral Candida } \\
\text { albicans; Brushings of oral } \\
\text { plaques }\end{array}$ & $\begin{array}{l}\text { TR-SMX; No treatment for } C \text {. } \\
\text { albicans co-infection } \\
\text { Resolution of symptoms }\end{array}$ \\
\hline 140 & $\begin{array}{l}77 \text { F- CD } \\
\text { Greece }\end{array}$ & $\begin{array}{l}\text { IFX (6 infusions } \\
\text { over } 8 \text { months) }\end{array}$ & $\begin{array}{l}\text { Methylprednisolone } \\
\text { and azathioprine } \\
\text { Glybenclamide for } \\
\text { type II diabetes } \\
\text { mellitus }\end{array}$ & $\begin{array}{l}P \text {. jirovecii pneumonia } \\
\text { Immunofluorescence } \\
\text { Pulmonary } N \text {. asteroides } \\
\text { Staining in bronchoalveolar } \\
\text { lavage; Oropharyngeal } \\
\text { infection with } C \text {. albicans } \\
\text { Oral swab } \\
\text { Airways infection with } A \text {. } \\
\text { baumanii, Pulmonary } P \text {. } \\
\text { mirabilis, Culture }\end{array}$ & $\begin{array}{l}\text { TR-SMX for } P \text {. jirovecii } \\
\text { Voriconazole for } C \text {. albicans } \\
\text { Meropenem for } A \text {. baumanii and } P \text {. } \\
\text { mirabilis } \\
\text { Resolution of symptoms }\end{array}$ \\
\hline 141 & $\begin{array}{l}57 \text { F- CD } \\
\text { Japan }\end{array}$ & IFX (4 infusions) & $\begin{array}{l}\text { Mesalazine, } \\
\text { prednisolone } \\
\text { azathioprine }\end{array}$ & $\begin{array}{l}P . \text { jirovecii } \\
\text { Staining in bronchoalveolar } \\
\text { lavage }\end{array}$ & $\begin{array}{l}\text { TR-SMX and methylprednisolone, } \\
\text { then pentamidine } \\
\text { Recovered after surgery for the } \\
\text { removal of a micro-abscess }\end{array}$ \\
\hline 142 & $\begin{array}{l}36 \mathrm{~F}-\mathrm{CD} \\
\mathrm{USA}\end{array}$ & IFX (2 infusions) & $\begin{array}{l}\text { 6-mercaptopurine, } \\
\text { mesalazine and } \\
\text { prednisone }\end{array}$ & $\begin{array}{l}P . \text { jirovecii pneumonia } \\
\text { Staining in bronchoalveolar } \\
\text { lavage }\end{array}$ & $\begin{array}{l}\text { Levofloxacin, metronidazole and } \\
\text { vancomycin, then TR-SMX and } \\
\text { methylprednisolone } \\
\text { Resolution of symptoms }\end{array}$ \\
\hline 143 & $\begin{array}{l}45 \mathrm{M}-\mathrm{UC} \\
\text { Spain }\end{array}$ & IFX (2 infusions) & $\begin{array}{l}\text { Azathioprine, } \\
\text { prednisone and } \\
\text { mesalazine }\end{array}$ & $\begin{array}{l}P . \text { jirovecii pneumonia } \\
\text { Staining in bronchoalveolar } \\
\text { lavage }\end{array}$ & $\begin{array}{l}\text { Imipenem, ciprofloxacin and } \\
\text { metronidazole, then TR-SMX } \\
\text { Resolution of symptoms }\end{array}$ \\
\hline
\end{tabular}


Table 3 (Continued). Fungal Infections in anti-TNF-treated IBD Patients

\begin{tabular}{|c|c|c|c|c|c|}
\hline Ref & $\begin{array}{l}\text { Patient } \\
\text { Demographics }\end{array}$ & Drug & $\begin{array}{l}\text { Co-medication/co- } \\
\text { infections }\end{array}$ & $\begin{array}{l}\text { Type of Infection; Method } \\
\text { of detection }\end{array}$ & Outcome \\
\hline 144 & $\begin{array}{l}36 \mathrm{M}-\mathrm{CD} \\
\text { Mexico }\end{array}$ & ADM for 8 weeks & $\begin{array}{l}\text { Azathioprine and } \\
\text { prednisone } \\
\text { Smoking history }\end{array}$ & $\begin{array}{l}P . \text { jirovecii pneumonia } \\
\text { Silver staining on bronchial } \\
\text { lavage } \\
\text { Direct immunofluorescence }\end{array}$ & $\begin{array}{l}\text { Imipenem, clarithromycin, TR- } \\
\text { SMX } \\
\text { Resolution of symptoms } \\
\quad \text { Continue............... }\end{array}$ \\
\hline 145 & $\begin{array}{l}56 \mathrm{~F}-\mathrm{CD} \\
\mathrm{USA}\end{array}$ & $\begin{array}{l}\text { IFX over } 12 \\
\text { months }\end{array}$ & 6-mercaptopurine & $\begin{array}{l}\text { Disseminated Histoplasma } \\
\text { capsulatum; Serum antigen } \\
\text { detection; Gomori's } \\
\text { methenamine silver } \\
\text { staining on pathology }\end{array}$ & $\begin{array}{l}\text { Itraconazole } \\
\text { Surgery } \\
\text { Resolution of symptoms }\end{array}$ \\
\hline 146 & $\begin{array}{l}8 \mathrm{M}-\mathrm{CD} \\
\text { USA }\end{array}$ & $\begin{array}{l}\text { IFX over } 15 \\
\text { months }\end{array}$ & $\begin{array}{l}\text { Mesalazine and 6- } \\
\text { mercaptopurine } \\
\text { Corticosteroids }\end{array}$ & $\begin{array}{l}\text { H. capsulatum } \\
\text { Urine antigen detection } \\
\text { Culture } P \text {. jirovicii } \\
\text { Silver staining on } \\
\text { pathology specimens }\end{array}$ & $\begin{array}{l}\text { Itraconazole, TR-SMX } \\
\text { Partial resolution of symptoms }\end{array}$ \\
\hline \multirow[t]{4}{*}{147} & $\begin{array}{l}16 \text { F- Pediatric CD } \\
\text { USA }\end{array}$ & ADM (4 doses) & 6-mercaptopurine & $\begin{array}{l}\text { Systemic Histoplasma sp. } \\
\text { histoplasmosis; Urine } \\
\text { antigen detection; Com- } \\
\text { plement fixation positive }\end{array}$ & $\begin{array}{l}\text { Itraconazole } \\
\text { Resolution of symptoms }\end{array}$ \\
\hline & $\begin{array}{l}14 \text { F- Pediatric CD } \\
\text { USA }\end{array}$ & IFX (2 infusions) & Methotrexate & $\begin{array}{l}\text { Histoplasmosis; Urine } \\
\text { antigen detection; } \\
\text { Complement fixation } \\
\text { positive }\end{array}$ & $\begin{array}{l}\text { Amphoteracin and intraconazole } \\
\text { Resolution of symptoms }\end{array}$ \\
\hline & $\begin{array}{l}13 \text { M- Crohn’s } \\
\text { colitis } \\
\text { USA }\end{array}$ & IFX (7 infusions) & 6-mercaptopurine & $\begin{array}{l}\text { Pulmonary histoplasmosis } \\
\text { Urine antigen detection } \\
\text { Complement fixation } \\
\text { positive }\end{array}$ & $\begin{array}{l}\text { Itraconazole } \\
\text { Resolution of symptoms }\end{array}$ \\
\hline & $\begin{array}{l}15 \text { F- Pediatric CD } \\
\text { USA }\end{array}$ & IFX (5 infusions) & 6-mercaptopurine & $\begin{array}{l}\text { Pulmonary histoplasmosis } \\
\text { with adenopathy } \\
\text { Urine and serum antigen } \\
\text { detection } \\
\text { Complement fixation } \\
\text { positive }\end{array}$ & $\begin{array}{l}\text { Amphoteracin and intraconazole } \\
\text { Resolution of symptoms }\end{array}$ \\
\hline
\end{tabular}


Table 3 (Continued). Fungal Infections in anti-TNF-treated IBD Patients

\begin{tabular}{|c|c|c|c|c|c|}
\hline Ref & $\begin{array}{l}\text { Patient } \\
\text { Demographics }\end{array}$ & Drug & $\begin{array}{l}\text { Co-medication/co- } \\
\text { infections }\end{array}$ & $\begin{array}{l}\text { Type of Infection; Method } \\
\text { of detection }\end{array}$ & Outcome \\
\hline 147 & $\begin{array}{l}21 \text { M- Crohn's } \\
\text { colitis } \\
\text { USA }\end{array}$ & IFX (13 infusions) & 6-mercaptopurine & $\begin{array}{l}\text { H. capsulatum; Serum } \\
\text { antigen detection; } \\
\text { Complement fixation } \\
\text { positive; Culture }\end{array}$ & $\begin{array}{l}\text { Itraconazole } \\
\text { Resolution of symptoms }\end{array}$ \\
\hline 148 & $\begin{array}{l}40 \mathrm{M}-\mathrm{CD} \\
\text { USA }\end{array}$ & $\begin{array}{l}\text { IFX over } 12 \\
\text { months }\end{array}$ & Prednisone & $\begin{array}{l}\text { H. capsulatum reactivation } \\
\text { Culture }\end{array}$ & $\begin{array}{l}\text { Itraconazole } \\
\text { Resolution of symptoms }\end{array}$ \\
\hline 149 & $\begin{array}{l}43 \mathrm{M}-\mathrm{CD} \\
\text { USA }\end{array}$ & IFX for 18 months & $\begin{array}{l}\text { Prednisone and } \\
\text { azathioprine }\end{array}$ & $\begin{array}{l}\text { H. epiglottitis; Biopsy, } \\
\text { Culture, Serum antigen } \\
\text { detection }\end{array}$ & $\begin{array}{l}\text { Amphotericin and itraconazole } \\
\text { Resolution of symptoms }\end{array}$ \\
\hline 150 & $\begin{array}{l}25 \mathrm{M}-\mathrm{CD} \\
\text { Netherlands }\end{array}$ & IFX (1 infusion) & $\mathrm{n} / \mathrm{a}$ & $\begin{array}{l}\text { A. fumigatus, Culture } \\
\text { Serum antigen detection } \\
\text { Post-mortem growth } \\
\text { identified in lungs }\end{array}$ & $\begin{array}{l}\text { High-dose corticosteroids and } \\
\text { liposomal amphotericin B } \\
\text { Death from multiorgan failure and } \\
\text { septic shock }\end{array}$ \\
\hline 151 & $\begin{array}{l}69 \mathrm{~F}-\mathrm{CD} \\
\text { Switzerland }\end{array}$ & ADM over 1 year & $\begin{array}{l}\text { Pre-existing renal } \\
\text { insufficiency and } \\
\text { chronic metabolic } \\
\text { acidosis }\end{array}$ & $\begin{array}{l}\text { Invasive aspergillosis } \\
\text { Bronchoscopy }\end{array}$ & $\begin{array}{l}\text { Antibiotics and fungostatic therapy } \\
\text { Death }\end{array}$ \\
\hline 152 & $\begin{array}{l}55 \mathrm{~F}-\mathrm{CD} \\
\text { USA }\end{array}$ & IFX ( 1 infusion) & $\begin{array}{l}\text { Azathioprine and } \\
\text { methylprednisolone } \\
\text { Interferon and } \\
\text { ribavirin for HCV } \\
\text { cirrhosis }\end{array}$ & $\begin{array}{l}\text { Pulmonary infection with } \\
\text { C. species, Culture } \\
\text { Aspergillus sp. (post- } \\
\text { mortem identified as } A \text {. } \\
\text { fumigatus), Culture }\end{array}$ & $\begin{array}{l}\text { Fluconazole initially for candidiasis } \\
\text { Amphotericin B added for } \\
\text { aspergillosis } \\
\text { Death from multiorgan failure }\end{array}$ \\
\hline 153 & $\begin{array}{l}20 \mathrm{M}-\mathrm{CD} \\
\text { USA, Spain }\end{array}$ & IFX over 3 months & $\begin{array}{l}\text { Prednisone } \\
\text { 6-mercaptopurine }\end{array}$ & $\begin{array}{l}\text { N. brasiliensis; } A \text {. } \\
\text { fumigatus and A. niger, } \\
\text { Culture }\end{array}$ & $\begin{array}{l}\text { Liezolid and voriconazole } \\
\text { Patient lost to follow-up }\end{array}$ \\
\hline 154 & $\begin{array}{l}61 \mathrm{M}-\mathrm{CD} \\
\text { USA }\end{array}$ & IFX over 2.5 years & $\begin{array}{l}\text { Prednisolone } \\
\text { Severe hip } \\
\text { osteonecrosis }\end{array}$ & $\begin{array}{l}\text { Asymptomatic } C \text {. } \\
\text { neoformans, Culture } \\
\text { Immunohistochemistry }\end{array}$ & $\begin{array}{l}\text { Amphotericin B and flucytosine } \\
\text { Fluconazole substituted for } \\
\text { amphotericin B due to renal } \\
\text { insufficiency } \\
\text { Resolution of symptoms } \\
\text { Continue ........ }\end{array}$ \\
\hline
\end{tabular}


Table 3 (Continued). Fungal Infections in anti-TNF-treated IBD Patients

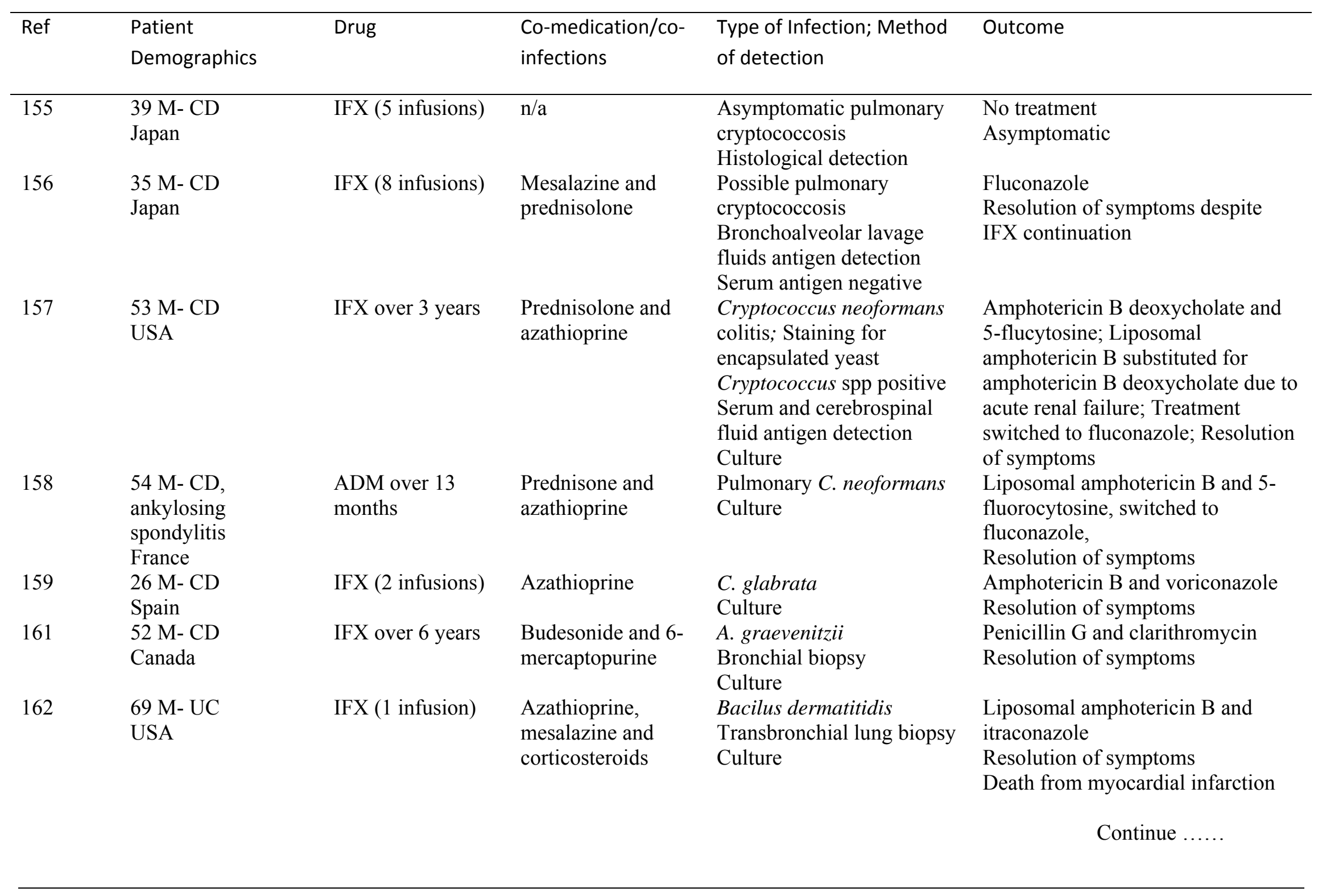


Table 3 (Continued). Fungal Infections in anti-TNF-treated IBD Patients

\begin{tabular}{|c|c|c|c|c|c|}
\hline Ref & $\begin{array}{l}\text { Patient } \\
\text { Demographics }\end{array}$ & Drug & $\begin{array}{l}\text { Co-medication/co- } \\
\text { infections }\end{array}$ & $\begin{array}{l}\text { Type of Infection; Method } \\
\text { of detection }\end{array}$ & Outcome \\
\hline 163 & $\begin{array}{l}50 \mathrm{M}-\mathrm{CD} \\
\text { USA }\end{array}$ & $\begin{array}{l}\text { IFX over } 4 \\
\text { months, then } \\
\text { ADM }\end{array}$ & $\begin{array}{l}\text { Mesalazine, } 6- \\
\text { mercaptopurine and } \\
\text { hyoscyamine }\end{array}$ & $\begin{array}{l}\text { C. immitis } \\
\text { Serology: IgM and IgG } \\
\text { antibodies positive in CSF } \\
\text { Lung leg biopsies p,ositive } \\
\text { Histological examination } \\
\text { Culture }\end{array}$ & $\begin{array}{l}\text { Broad-spectrum antimicrobials } \\
\text { Fluconazole and amphotericin B } \\
\text { liposomal complex; Death from } \\
\text { disseminated coccidioidomycosis }\end{array}$ \\
\hline
\end{tabular}

Table 4. Viral Infections in anti-TNF-treated IBD Patients

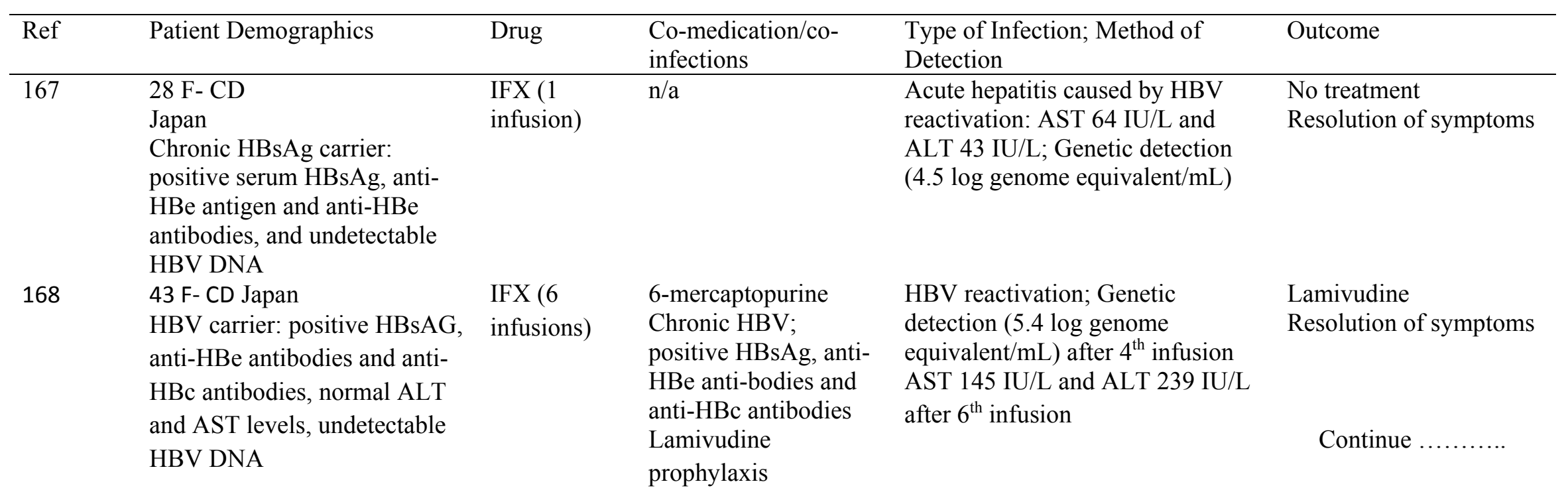


Table 4 (Continued). Viral Infections in anti-TNF-treated IBD Patients

\begin{tabular}{|c|c|c|c|c|c|}
\hline Ref & $\begin{array}{l}\text { Patient } \\
\text { Demographics }\end{array}$ & Drug & $\begin{array}{l}\text { Co-medication/co- } \\
\text { infections }\end{array}$ & Type of Infection; Method of Detection & Outcome \\
\hline 169 & $\begin{array}{l}34 \text { M- CD } \\
\text { Spain } \\
\text { Baseline HBV } \\
\text { status unknown }\end{array}$ & $\begin{array}{l}\text { IFX }(1 \\
\text { dose })\end{array}$ & $\begin{array}{l}\text { Azathioprine } \\
\text { HBV infection } \\
\text { determined after } \\
\text { reactivation in archival } \\
\text { serum, positive HBsAg, } \\
\text { HBeAg, IgG anti-HBc } \\
\text { antibodies, and HBV } \\
\text { DNA }\end{array}$ & $\begin{array}{l}\text { Acute hepatitis caused by HBV reactivation: ALT } \\
2089 \mathrm{IU} / \mathrm{L}, \mathrm{AST} 1561 \mathrm{IU} / \mathrm{L}, \mathrm{ALP} 540 \mathrm{IU} / \mathrm{L}, \gamma- \\
\text { GTP } 165 \mathrm{IU} / \mathrm{L} \text { and total bilirubin } 1.7 \\
\text { mg/dLHBsAg, IgG anti-HBc antibodies and } \\
\text { HBeAg positive, and negative anti-HBs } \\
\text { antibodies, IgM anti-HBc antibodies, anti-HBe } \\
\text { antibodies }\end{array}$ & $\begin{array}{l}\text { Seroconversion from } \\
\text { HBeAg to anti-HBe } \\
\text { antibodies } \\
\text { HBsAg cleared } \\
\text { HBV DNA undetectable } \\
\text { Resolution of symptoms. }\end{array}$ \\
\hline 169 & $\begin{array}{l}38 \mathrm{M}-\mathrm{CD} \\
\text { Spain } \\
\text { Chronic HBV: } \\
\text { HBsAg, IgG anti- } \\
\text { HBc and anti- } \\
\text { HBe antibodies } \\
\text { positive, negative } \\
\text { HBeAg and HBV } \\
\text { DNA }\end{array}$ & $\begin{array}{l}\text { IFX (3 } \\
\text { doses) }\end{array}$ & $\begin{array}{l}\text { Azathioprine and } \\
\text { metronidazole }\end{array}$ & $\begin{array}{l}\text { Hepatic failure with ascites caused by } \mathrm{HBV} \\
\text { reactivation: ALT } 2225 \mathrm{IU} / \mathrm{L}, \mathrm{AST} 2146 \mathrm{IU} / \mathrm{L}, \gamma- \\
\text { GTP } 227 \mathrm{U} / \mathrm{L} \text {, total bilirubin } 24.1 \mathrm{mg} / \mathrm{dL} \\
\text { HBeAg and IgM anti-HBc antibodies positive }\end{array}$ & $\begin{array}{l}\text { Death from variceal } \\
\text { bleeding, } \\
\text { encephalopathy, } \\
\text { hepatorenal syndrome. }\end{array}$ \\
\hline 170 & $\begin{array}{l}54 \mathrm{M}-\mathrm{CD} \\
\text { USA } \\
\text { Chronic HBV }\end{array}$ & $\begin{array}{l}\text { IFX over } 2 \\
\text { years }\end{array}$ & $\begin{array}{l}\text { Azathioprine and } \\
\text { prednisone } \\
\text { Chronic HBV }\end{array}$ & $\begin{array}{l}\text { Fulminant hepatic failure caused by } \mathrm{HBV} \\
\text { reactivation } \\
\mathrm{AST} 143 \mathrm{U} / \mathrm{L}, \mathrm{ALT} 124 \mathrm{U} / \mathrm{L} \text { and bilirubin } 2.7 \\
\mathrm{mg} / \mathrm{dL} \text {; HBsAg and HBeAg positive; IgM anti- } \\
\mathrm{HBc} \text { antibodies subsequently positive }\end{array}$ & $\begin{array}{l}\text { Lamivudine } \\
\text { Death from stage } 4 \\
\text { hepatic encephalopathy, } \\
\text { jaundice, hepatorenal } \\
\text { syndrome and } \\
\text { hemodynamic } \\
\text { instability. } \\
\text { of symptoms }\end{array}$ \\
\hline
\end{tabular}


Table 4 (Continued). Viral Infections in anti-TNF-treated IBD Patients

\begin{tabular}{|c|c|c|c|c|c|}
\hline Ref & Patient Demographics & Drug & $\begin{array}{l}\text { Co-medication/co- } \\
\text { infections }\end{array}$ & $\begin{array}{l}\text { Type of Infection; Method of } \\
\text { Detection }\end{array}$ & Outcome \\
\hline 171 & $\begin{array}{l}50 \mathrm{M}-\mathrm{CD} \\
\text { Austria } \\
\text { Baseline HBV status unknown }\end{array}$ & $\begin{array}{l}\text { IFX (3 } \\
\text { infusions) }\end{array}$ & $\begin{array}{l}\text { Azathioprine } \\
\text { Mirtazapine, } \\
\text { pantoprazole, } \\
\text { brotizolam } \\
\text { Previously unknown } \\
\text { HBV carrier, with } \\
\text { positive HBsAg and } \\
\text { low viral load in } \\
\text { archival serum }\end{array}$ & $\begin{array}{l}\text { Subfulminant hepatitis caused by } \\
\text { HBV reactivation; ALT } 983 \mathrm{IU} / \mathrm{L} \text {, } \\
\text { AST } 413 \mathrm{IU} / \mathrm{L}, \gamma \text {-GTP } 109 \mathrm{IU} / \mathrm{L} \text {, } \\
\text { LDH } 237 \mathrm{IU} / \mathrm{L} \text { and bilirubin } 2.17 \\
\mathrm{mg} / \mathrm{d} \text {; HBsAg, anti-HBe- and } \\
\text { HBc-antibodies positive, and } \\
\text { negative HBeAGg and IgM anti- } \\
\text { HBc antibodies; Genetic } \\
\text { detection }\left(>2.2 \times 10^{8} \text { copies } / \mathrm{mL}\right)\end{array}$ & $\begin{array}{l}\text { Lamivudine } \\
\text { Progressing to mild } \\
\text { hepatic encephalopathy } \\
\text { Eventual resolution }\end{array}$ \\
\hline 172 & $\begin{array}{l}58 \text { F- UC } \\
\text { Spain } \\
\text { Baseline HBV status unknown }\end{array}$ & $\begin{array}{l}\text { IFX over } 1 \\
\text { year }\end{array}$ & $\begin{array}{l}\text { Prednisone, then } \\
\text { azathioprine } \\
\text { Chronic HBV } \\
\text { infection was } \\
\text { presumed after } \\
\text { reactivation }\end{array}$ & $\begin{array}{l}\text { HBV reactivation, AST } 1015 \\
\text { IU/L, ALT } 994 \mathrm{IU} / \mathrm{L} ; \mathrm{HBsAg} \text { and } \\
\text { anti-HBc antibodies positive, } \\
\text { negative } \mathrm{HBe} A g \text { and anti-HBs } \\
\text { antibodies } \\
\text { Genetic detection }(463 \mathrm{IU} / \mathrm{mL})\end{array}$ & $\begin{array}{l}\text { Entecavir } \\
\text { Resolution of symptoms }\end{array}$ \\
\hline 174 & $\begin{array}{l}41 \mathrm{~F}-\mathrm{CD} \\
\text { Italy } \\
\text { Baseline HBV status thought } \\
\text { to be negative }\end{array}$ & $\begin{array}{l}\text { IFX over } 2 \\
\text { years }\end{array}$ & $\begin{array}{l}\text { Prednisone } \\
\text { Baseline HBsAg } \\
\text { negative, anti-HBc, } \\
\text { anti-HBe antibodies } \\
\text { not assessed, trans- } \\
\text { aminases within limit }\end{array}$ & $\begin{array}{l}\text { HBV reactivation: AST } 6 \times \mathrm{ULN} \text {, } \\
\mathrm{ALT} 10 \times \mathrm{ULN} \text {; bilirubin } 1.5 \\
\mathrm{mg} / \mathrm{dL} ; \mathrm{HBsAg} \text {, anti-HBe } \\
\text { antibodies and IgM anti-HBc } \\
\text { antibodies positive, and negative } \\
\text { HbeAg }\end{array}$ & $\begin{array}{l}\text { Lamivudine } \\
\text { Initial exacerbation } \\
\text { followed by eventual } \\
\text { resolution of symptoms }\end{array}$ \\
\hline 207 & $\begin{array}{l}63 \text { F- CD } \\
\text { Switzerland }\end{array}$ & $\begin{array}{l}\text { IFX }(1 \\
\text { infusion })\end{array}$ & $\begin{array}{l}\text { Corticosteroids and } \\
\text { azathioprine }\end{array}$ & $\begin{array}{l}\text { CMV hemorrhagic ileocolitis with } \\
\text { impaired cerebral function } \\
\text { Colonoscopy } \\
\text { Biopsy; IgM positive }\end{array}$ & $\begin{array}{l}\text { Foscarnet, ganciclovir } \\
\text { metronidazole, } \\
\text { ciprofloxacin } \\
\text { Resolution of symptoms }\end{array}$ \\
\hline
\end{tabular}


Table 4 (Continued). Viral Infections in anti-TNF-treated IBD Patients

\begin{tabular}{|c|c|c|c|c|c|}
\hline Ref & $\begin{array}{l}\text { Patient } \\
\text { Demographics }\end{array}$ & Drug & Co-medication/co-infections & $\begin{array}{l}\text { Type of Infection; Method of } \\
\text { Detection }\end{array}$ & Outcome \\
\hline 208 & $\begin{array}{l}22 \mathrm{M}-\mathrm{CD} \\
\mathrm{USA}\end{array}$ & IFX for 4 months & 6-mercaptopurine & $\begin{array}{l}\text { CMV ileocolitis and } \\
\text { hemophagocytic syndrome } \\
\text { Biopsy immunostaining positive } \\
\text { IgM and IgG positive } \\
\text { Generic detection ( } 134000 \\
\text { copies/mL }\end{array}$ & $\begin{array}{l}\text { Ganciclovir } \\
\text { Splenectomy for } \\
\text { splenomegaly } \\
\text { Resolution of symptoms }\end{array}$ \\
\hline 209 & $\begin{array}{l}9 \mathrm{M}-\mathrm{CD} \\
\mathrm{USA}\end{array}$ & IFX & $\begin{array}{l}\text { 6-mercaptopurine } \\
\text { Sickle cell anemia }\end{array}$ & $\begin{array}{l}\text { CMV colitis and multiorgan } \\
\text { failure, IgM and IgG positive } \\
\text { Colon biopsy, } \\
\text { Immunohistochemistry staining }\end{array}$ & $\begin{array}{l}\text { Vancomycin ticarcillin- } \\
\text { clavulanate; ganciclovir } \\
\text { Death from respiratory and } \\
\text { hepatic failure }\end{array}$ \\
\hline 210 & $\begin{array}{l}45 \mathrm{~F}-\mathrm{CD} \\
\mathrm{USA}\end{array}$ & IFX for 1 year & $\begin{array}{l}\text { 6-mercaptopurine and } \\
\text { prednisone; Evo-thyroxine } \\
\text { replacement for Sheehan } \\
\text { syndrome }\end{array}$ & $\begin{array}{l}\text { CMV hepatitis } \\
\text { Paraffin immunoperoxidase } \\
\text { staining positive } \\
\text { IgM and IgG positve }\end{array}$ & $\begin{array}{l}\text { Ganciclovir } \\
\text { Resolution of symptoms }\end{array}$ \\
\hline 212 & $\begin{array}{l}\text { 26M- CD } \\
\text { USA }\end{array}$ & $\begin{array}{l}\text { IFX ( } 9 \text { days after } \\
1 \text { st dose) }\end{array}$ & $\begin{array}{l}\text { 6-mercaptopurine, } \\
\text { mesalazine and } \\
\text { corticosteroids }\end{array}$ & $\begin{array}{l}\text { Primary VZV } \\
\text { Direct fluorescent antigen positive } \\
\text { Streptococcus } \\
\text { Culture }\end{array}$ & $\begin{array}{l}\text { Acyclovir } \\
\text { Death due to fulminant } \\
\text { hepatic failure, disseminated } \\
\text { intravascular coagulation, } \\
\text { respiratory failure and } \\
\text { oliguric renal failure }\end{array}$ \\
\hline 213 & $\begin{array}{l}12 \mathrm{~F}-\mathrm{CD} \\
\mathrm{USA} \\
14 \mathrm{M}-\mathrm{CD} \\
\mathrm{USA}\end{array}$ & IFX for 2 years & $\begin{array}{l}\text { Methotrexate and prednisone } \\
\text { Hydrocortisone and 6- } \\
\text { mercaptopurine }\end{array}$ & $\begin{array}{l}\text { Primary VZV } \\
\text { Direct fluorescent antigen positive } \\
\text { VZV reactivation } \\
\text { Direct fluorescent antigen positive }\end{array}$ & $\begin{array}{l}\text { Valacyclovir and acyclovir } \\
\text { Resolution of symptoms }\end{array}$ \\
\hline 214 & $\begin{array}{l}12 \mathrm{~F}-\mathrm{UC} \\
\text { Italy }\end{array}$ & IFX for 6 months & Mesalazine and azathioprine & $\begin{array}{l}\text { Herpes zoster followed by } \\
\text { Henoch-Schönlein purpura }\end{array}$ & $\begin{array}{l}\text { Aciclovir } \\
\text { Resolution of symptoms }\end{array}$ \\
\hline 215 & $\begin{array}{l}20 \mathrm{M}-\mathrm{CD} \\
\text { Portugal }\end{array}$ & $\begin{array}{l}\text { IFX ( } 7 \text { infusions } \\
\text { over } 10 \text { months) }\end{array}$ & $\mathrm{n} / \mathrm{a}$ & $\begin{array}{l}\text { VZV reactivation } \\
\text { Genetic determination }\end{array}$ & $\begin{array}{l}\text { Valacyclovir } \\
\text { Resolution of symptoms }\end{array}$ \\
\hline
\end{tabular}


Table 4 (Continued). Viral Infections in anti-TNF-treated IBD Patients

\begin{tabular}{|c|c|c|c|c|c|}
\hline Ref & Patient Demographics & Drug & $\begin{array}{l}\text { Co-medication/co- } \\
\text { infections }\end{array}$ & $\begin{array}{l}\text { Type of Infection; Method of } \\
\text { Detection }\end{array}$ & Outcome \\
\hline 216 & $\begin{array}{l}36 \mathrm{~F}-\mathrm{CD} \\
\text { Belgium }\end{array}$ & $\begin{array}{l}\text { IFX over } 5 \\
\text { months }\end{array}$ & $\mathrm{n} / \mathrm{a}$ & Herpes zoster & $\begin{array}{l}\text { Aciclovir } \\
\text { Resolution of symptoms }\end{array}$ \\
\hline 217 & $\begin{array}{l}\text { 51- F Rectocolitis } \\
\text { Belgium }\end{array}$ & $\begin{array}{l}\text { IFX over } 8 \\
\text { years }\end{array}$ & $\begin{array}{l}\text { Prednisone; Previous } \\
\text { exposure to IFX }\end{array}$ & $\begin{array}{l}\text { VZV reactivation with meningitis } \\
\text { Genetic detection }\end{array}$ & $\begin{array}{l}\text { Acyclovir, then } \\
\text { valacyclovir } \\
\text { Slow recovery, with } \\
\text { final outcome not } \\
\text { reported }\end{array}$ \\
\hline 218 & $\begin{array}{l}38 \mathrm{M}-\mathrm{CD} \\
\text { China } \\
43 \mathrm{~F}-\mathrm{CD} \\
\text { China }\end{array}$ & $\begin{array}{l}\text { IFX (12 } \\
\text { infusions) } \\
\text { IFX (1 } \\
\text { infusion) }\end{array}$ & $\mathrm{n} / \mathrm{a}$ & Herpes zoster & $\begin{array}{l}\text { Ganciclovir, potassium- } \\
\text { sodium dehydroandroan } \\
\text { Resolution of symptoms }\end{array}$ \\
\hline 219 & $\begin{array}{l}45 \mathrm{~F}-\mathrm{CD} \\
\mathrm{USA} \\
25 \mathrm{~F}-\mathrm{CD} \\
\mathrm{USA} \\
17 \mathrm{~F}-\mathrm{CD} \\
\text { USA }\end{array}$ & $\begin{array}{l}\text { IFX }(1 \\
\text { infusion }) \\
\text { IFX (3 } \\
\text { infusions }) \\
\text { IFX (2 } \\
\text { infusions) }\end{array}$ & 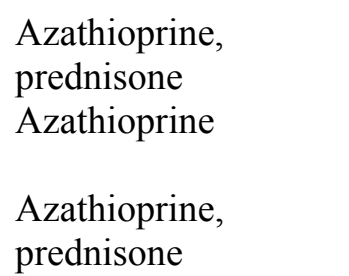 & $\begin{array}{l}\text { VZV manifesting as shingles } \\
\text { VZV manifesting as chickenpox } \\
\text { VZV manifesting as shingles }\end{array}$ & $\begin{array}{l}\text { Treatment not specified } \\
\text { Resolution of symptoms }\end{array}$ \\
\hline 220 & $\begin{array}{l}29 \mathrm{~F}-\mathrm{CD} \\
\text { France } \\
25 \mathrm{~F}-\mathrm{CD} \\
\text { France } \\
39 \mathrm{M}-\mathrm{CD} \\
\text { France } \\
33 \mathrm{M}-\mathrm{CD} \\
\text { France } \\
\end{array}$ & $\begin{array}{l}\text { IFX over } 2 \\
\text { years } \\
\text { IFX over } 4 \\
\text { years } \\
\text { IFX over } 36 \\
\text { weeks } \\
\text { IFX }\end{array}$ & $\mathrm{n} / \mathrm{a}$ & $\begin{array}{l}\text { Herpes zoster } \\
\text { Herpes zoster with lumbar } \\
\text { presentation } \\
\text { Herpes zoster with dorsal } \\
\text { presentation } \\
\text { Herpes zoster with cervical multi- } \\
\text { metameric presentation }\end{array}$ & $\begin{array}{l}\text { Aciclovir } \\
\text { Resolution of symptoms } \\
\text { Vancomycin, aciclovir; } \\
\text { Resolution of symptoms }\end{array}$ \\
\hline
\end{tabular}




\section{REFERENCES}

1. Munkholm P, Langholz E, Davidsen M, Binder $\mathrm{V}$. Disease activity courses in a regional cohort of Crohn's disease patients. Scand J Gastroenterol. 1995;30:699-706.

2. Faubion WA Jr, Loftus EV Jr, Harmsen WS, Zinsmeister AR, Sandborn WJ. The natural history of corticosteroid therapy for inflammatory bowel disease: a population-based study. Gastroenterology. 2001;121:255-60.

3. Jacobson-Brown P, Neuman MG. Colorectal polyposis and immune-based therapies. Can J Gastroenterol. 2004;18:239-49.

4. Neuman MG. Immune dysfunction in inflammatory bowel disease. Transl Res. 2007;149:173-86.

5. Cohen LE, Nanau RM, Delzor F, Neuman MG. Biologic therapies in inflammatory bowel disease. Transl Res. 2014;163:533-56.

6. Ibrahim A, Katz GG, Neuman MG. Tumor necrosis factor alpha as a noninvasive marker of liver inflammation in patients with viral hepatitis C. Am Clin Lab. 2002;21:12-5.

7. Sandborn WJ, Hanauer SB, Katz S, Safdi M, Wolf DG, Baerg RD, Tremaine WJ, Johnson T, Diehl NN, Zinsmeister AR. Etanercept for active Crohn's disease: a randomized, doubleblind, placebo-controlled trial. Gastroenterology. 2001;121:1088-94.

8. Singh JA, Wells GA, Christensen R, Tanjong Ghogomu E, Maxwell L, Macdonald JK, Filippini G, Skoetz N, Francis D, Lopes LC, Guyatt GH, Schmitt J, La Mantia L, Weberschock T, Roos JF, Siebert H, Hershan S, Lunn MP, Tugwell P, Buchbinder R. Adverse effects of biologics: a network meta-analysis and Cochrane overview. Cochrane Database Syst Rev. 2011:CD008794.

9. Janssen Biotech, Inc. REMICADE® (infliximab). Highlights of Prescribing Information. 2013. http://www.remicade.com/shared/product/remica de/prescribing-information.pdf.

10. AbbVie, Inc. HUMIRA ${ }^{\circledR}$ (adalimumab). Highlights of Prescribing Information. 2013. http://www.rxabbvie.com/pdf/humira.pdf.

11. UCB, Inc. CIMZIA ${ }^{\circledR}$ (certolizumab pegol). Highlights of Prescribing Information. 2012. http://www.cimzia.com/pdf/Prescribing Informa tion.pdf.

12. Janssen Biotech, Inc. SIMPONI ${ }^{\circledR}$ (golimumab). Highlights of Prescribing Information. 2013. http:/www.simponi.com/sites/default/files/pdf/p rescribing-information.pdf.
13. Hanson RL, Gannon MJ, Khamo N, Sodhi M, Orr AM, Stubbings J. Improvement in safety monitoring of biologic response modifiers after the implementation of clinical care guidelines by a specialty. J Manag Care Pharm. 2013;19:49-67.

14. Springer TA. Traffic signals for lymphocyte recirculation and leukocyte emigration: the multistep paradigm. Cell. 1994;76:301-14.

15. Danese S, Semeraro S, Marini M, Roberto I, Armuzzi A, Papa A, Gasbarrini A. Adhesion molecules in inflammatory bowel disease: therapeutic implications for gut inflammation. Dig Liver Dis. 2005;37:811-8.

16. Jones SC, Banks RE, Haidar A, Gearing AJ, Hemingway IK, Ibbotson SH, Dixon MF, Axon AT. Adhesion molecules in inflammatory bowel disease. Gut 1995;36:72430.

17. Ghosh N, Chaki R, Mandal SC. Inhibition of selective adhesion molecules in treatment of inflammatory bowel disease. Int Rev Immunol. 2012;31:410-27.

18. Lawrance IC, Radford-Smith GL, Bampton PA, Andrews JM, Tan PK, Croft A, Gearry RB, Florin TH. Serious infections in patients with inflammatory bowel disease receiving antitumor-necrosis-factor-alpha therapy: an Australian and New Zealand experience. J Gastroenterol Hepatol. 2010;25:1732-8.

19. Salmon-Ceron D, Tubach F, Lortholary O, Chosidow O, Bretagne S, Nicolas

N, Cuillerier E, Fautrel B, Michelet C, Morel J, Puéchal X, Wendling D, Lemann M,Ravaud $\mathrm{P}$, Mariette X. Drug-specific risk of nontuberculosis opportunistic infections in patients receiving anti-TNF therapy reported to the 3-year prospective French RATIO registry. Ann Rheum Dis. 2011;70:616-23.

20. Marehbian J, Arrighi HM, Hass S, Tian H, Sandborn WJ. Adverse events associated with common therapy regimens for moderate-tosevere Crohn's disease. Am J Gastroenterol. 2009;104:2524-33.

21. Baddley JW, Winthrop KL, Chen L, Liu L, Grijalva CG, Delzell E, Beukelman T, Patkar NM, Xie F, Saag KG, Herrinton LJ, Solomon DH, Lewis JD, Curtis JR. Non-viral opportunistic infections in new users of tumour necrosis factor inhibitor therapy: results of the SAfety Assessment of Biologic ThERapy (SABER) Study. Ann Rheum Dis. 2013. In press. doi: 10.1136/annrheumdis-2013-203407.

22. Hyams J, Crandall W, Kugathasan S, Griffiths A, Olson A, Johanns J, Liu G, Travers S, Heuschkel R, Markowitz J, Cohen S, Winter H, Veereman-Wauters G, Ferry G, Baldassano R. 
Induction and maintenance infliximab therapy for the treatment of moderate-to-severe Crohn's disease in children. Gastroenterology. 2007;132:863-73.

23. Hyams J, Walters TD, Crandall W, Kugathasan S, Griffiths A, Blank M, Johanns J, Lang Y, Markowitz J, Cohen S, Winter HS, Veereman-Wauters G, Ferry G, Baldassano $R$. Safety and efficacy of maintenance infliximab therapy for moderate-to-severe Crohn's disease in children: REACH open-label extension. Curr Med Res Opin. 2011;27:651-62.

24. Hyams J, Damaraju L, Blank M, Johanns J, Guzzo C, Winter HS, Kugathasan S, Cohen S, Markowitz J, Escher JC, Veereman-Wauters G, Crandall W, Baldassano R, Griffiths A. Induction and maintenance therapy with infliximab for children with moderate to severe ulcerative colitis. Clin Gastroenterol Hepatol. 2012;10:391-9.

25. Toussi SS, Pan N, Walters HM, Walsh TJ. Infections in children and adolescents with juvenile idiopathic arthritis and inflammatory bowel disease treated with tumor necrosis factor$\alpha$ inhibitors: systematic review of the literature. Clin Infect Dis. 2013;57:1318-30.

26. Rutgeerts P, Sandborn WJ, Feagan BG, Reinisch W, Olson A, Johanns J, Travers S, Rachmilewitz D, Hanauer SB, Lichtenstein GR, de Villiers WJ, Present D, Sands BE, Colombel JF. Infliximab for induction and maintenance therapy for ulcerative colitis. $\mathrm{N}$ Engl $\mathrm{J}$ Med. 2005;353:2462-76.

27. Hanauer SB, Feagan BG, Lichtenstein GR, Mayer LF, Schreiber S, Colombel JF, Rachmilewitz D, Wolf DC, Olson A, Bao W, Rutgeerts P. Maintenance infliximab for Crohn's disease: the ACCENT I randomised trial. Lancet. 2002;359:1541-9.

28. Cottone M, Kohn A, Daperno M, Armuzzi A, Guidi L, D'Inca R, Bossa F, Angelucci E, Biancone L, Gionchetti P, Ardizzone S, Papi C, Fries W, Danese S, Riegler G, Cappello M, Castiglione F, Annese V, Orlando A. Advanced age is an independent risk factor for severe infections and mortality in patients given anti-tumor necrosis factor therapy for inflammatory bowel disease. Clin Gastroenterol Hepatol. 2011;9:30-5.

29. Colombel JF, Sandborn WJ, Rutgeerts P, Enns R, Hanauer SB, Panaccione R, Schreiber S, Byczkowski D, Li J, Kent JD, Pollack PF. Adalimumab for maintenance of clinical response and remission in patients with Crohn's disease: the CHARM trial. Gastroenterology. 2007;132:52-65.
30. Rutgeerts P, Van Assche G, Sandborn WJ, Wolf DC, Geboes K, Colombel JF, Reinisch W; EXTEND Investigators, Kumar A, Lazar A, Camez A, Lomax KG,Pollack PF, D'Haens G. Adalimumab induces and maintains mucosal healing in patients with Crohn's disease: data from the EXTEND trial. Gastroenterology. 2012;142:1102-11.

31. Sandborn WJ, Feagan BG, Stoinov S, Honiball PJ, Rutgeerts P, Mason D, Bloomfield R, Schreiber S. Certolizumab pegol for the treatment of Crohn's disease. $\mathrm{N}$ Engl $\mathrm{J}$ Med. 2007;357:228-38.

32. Schreiber S, Khaliq-Kareemi M, Lawrance IC, Thomsen OØ, Hanauer SB, McColm J, Bloomfield R, Sandborn WJ. Maintenance therapy with certolizumab pegol for Crohn's disease. N Engl J Med. 2007;357:239-50.

33. Sandborn WJ, Feagan BG, Marano C, Zhang H, Strauss R, Johanns J, Adedokun OJ, Guzzo C, Colombel JF, Reinisch W, Gibson PR, Collins J, Järnerot G, Hibi T, Rutgeerts P. Subcutaneous Golimumab Induces Clinical Resp onse and Remission in Patients With Moderateto-Severe Ulcerative Colitis. Gastroenterology. 2014;146:85-95.

34. Sandborn WJ, Feagan BG, Marano C, Zhang H, Strauss R, Johanns J, Adedokun OJ, Guzzo C, Colombel JF, Reinisch W, Gibson PR, Collins J, Järnerot $\quad \mathrm{G}, \quad$ Rutgeerts $P$. Subcutaneous Golimumab Maintains Clinical Re sponse in Patients With Moderate-to-Severe Ulcerative Colitis. Gastroenterology. 2014b;146:96-109.

35. Singh JA, Noorbaloochi S, Singh G. Golimumab for rheumatoid arthritis. Cochrane Database Syst Rev. 2010:CD008341.

36. Singh JA, Noorbaloochi S, Singh G. Golimumab for rheumatoid arthritis: a systematic review. J Rheumatol. 2010;37:1096-104.

37. Kavanaugh A, McInnes IB, Mease PJ, Krueger GG, Gladman DD, van der Heijde D, Mudivarthy S, Xu W, Mack M, Xu Z, Beutler A. Clinical efficacy, radiographic and safety findings through 2 years of golimumab treatment in patients with active psoriatic arthritis: results from a long-term extension of the randomised, placebo-controlled GO-REVEAL study. Ann Rheum Dis. 2013;72:1777-85.

38. Nordgaard-Lassen I, Dahlerup JF, Belard E, Gerstoft J, Kjeldsen J, Kragballe K, Ravn P, Sørensen IJ, Theede K, Tjellesen L. Guidelines for screening, prophylaxis and critical information prior to initiating anti-TNF-alpha treatment. Dan Med J. 2012;59:C4480. 
39. Mariette X, Gottenberg JE, Ravaud P, Combe B. Registries in rheumatoid arthritis and autoimmune diseases: data from the French registries. Rheumatology (Oxford). 2011;50:2229.

40. Lee SK, Kim SY, Kim EY, Jung JY, Park MS, Kim YS, Kim SK, Chang J, Kang YA. Mycobacterial infections in patients treated with tumor necrosis factor antagonists in South Korea. Lung. 2013;191:565-71.

41. Abreu C, Magro F, Santos-Antunes J, Pilão A, Rodrigues-Pinto E, Bernardes J, Bernardo A, Magina S, Vilas-Boas F, Lopes S, Macedo $\mathrm{G}$, Sarmento A. Tuberculosis in anti-TNF- $\alpha$ treated patients remains a problem in countries with an intermediate incidence: analysis of 25 patients matched with a control population. J Crohns Colitis. 2013;7:e486-92.

42. Nam JL, Winthrop KL, van Vollenhoven RF, Pavelka K, Valesini G, Hensor EM, Worthy G, Landewé R, Smolen JS, Emery P, Buch MH. Current evidence for the management of rheumatoid arthritis with biological diseasemodifying antirheumatic drugs: a systematic literature review informing the EULAR recommendations for the management of RA. Ann Rheum Dis. 2010;69:976-86.

43. Silva LC, Geluk A, Arnone M, Romiti R, Franken KC, Duarte AJ, Takahashi $\mathrm{MD}$, Benard G. Infliximab partially impairs the anti-Mycobacterium tuberculosis immune responses of severe psoriasis patients with positive tuberculin skin-test. J Eur Acad Dermatol Venereol. 2012;26:319-24.

44. Saliu OY, Sofer C, Stein DS, Schwander SK, Wallis RS. Tumor-necrosis-factor blockers: differential effects on mycobacterial immunity. J Infect Dis. 2006;194:486-92.

45. Wallis RS. Reactivation of latent tuberculosis by TNF blockade: the role of interferon gamma. J Investig Dermatol Symp Proc. 2007;12:16-21.

46. Harris J, Hope JC, Keane J. Tumor necrosis factor blockers influence macrophage responses to Mycobacterium tuberculosis. J Infect Dis. 2008;198:1842-50.

47. González-Sixto B, Rodríguez-Prieto MA. Etanercept and infection - latent tuberculosis. Actas Dermosifiliogr. 2010;101 Suppl 1:62-9.

48. Harris J, Keane J. How tumour necrosis factor blockers interfere with tuberculosis immunity. Clin Exp Immunol. 2010;161:1-9.

49. Gardam MA, Keystone EC, Menzies R, Manners S, Skamene E, Long R, Vinh DC. Anti-tumour necrosis factor agents and tuberculosis risk: mechanisms of action and clinical management. Lancet Infect Dis. 2003;3:148-55.
50. Furst DE, Wallis R, Broder M, Beenhouwer DO. Tumor necrosis factor antagonists: different kinetics and/or mechanisms of action may explain differences in the risk for developing granulomatous infection. Semin Arthritis Rheum. 2006;36:159-67.

51. Bruns $\mathrm{H}$, Meinken $\mathrm{C}$, Schauenberg $\mathrm{P}$, Härter G, Kern P, Modlin RL, Antoni C, Stenger S. Anti-TNF immunotherapy reduces CD8+ T cellmediated antimicrobial activity against Mycobacterium tuberculosis in humans. J Clin Invest. 2009;119:1167-77.

52. Redford PS, Murray PJ, O'Garra A. The role of IL-10 in immune regulation during $\mathrm{M}$. tuberculosis infection. Mucosal Immunol. 2011;4:261-70.

53. Salgado E, Gómez-Reino JJ. The risk of tuberculosis in patients treated with TNF antagonists. Expert Rev Clin Immunol. 2011;7:329-40.

54. Cardoso IP, de Almeida NP, Gotardo DR, Cardeal M, Santana GO. Tuberculin skin testing in inflammatory bowel disease patients from an endemic area of Brazil. Braz J Infect Dis. 2014;18:60-4.

55. Navarra SV, Tang B, Lu L, Lin HY, Mok CC, Asavatanabodee P, Suwannalai P, Hussein H, Rahman MU. Risk of tuberculosis with antitumor necrosis factor- $\alpha$ therapy: substantially higher number of patients at risk in Asia. Int $\mathbf{J}$ Rheum Dis. 2014;17:291-8.

56. Solovic I, Sester M, Gomez-Reino JJ, Rieder HL, Ehlers S, Milburn HJ, Kampmann B, Hellmich B, Groves R, Schreiber S, Wallis RS, Sotgiu G, Schölvinck EH,Goletti D, Zellweger JP, Diel R, Carmona L, Bartalesi F, Ravn P, Bossink A, Duarte R, Erkens C, Clark J, Migliori GB, Lange C. The risk of tuberculosis related to tumour necrosi s factor antagonist therapies:

a TBNET consensus statement. Eur Respir J. 2010;36:1185-206.

57. Agarwal SK. Biologic agents in rheumatoid arthritis: an update for managed care professionals. J Manag Care Pharm. 2011;17:S14-8.

58. Amerio P, Amoruso G, Bardazzi F, Campanati A, Cassano N, Conti A, Gisondi P, Guarneri C, Mazzotta A, Piaserico S, Prestinari F, Prignano F, Zane C, de Simone C. Detection and management of latent tuberculosis infections before biologic therapy for psoriasis. J Dermatolog Treat. 2013;24:305-11.

59. Reenaers C, Belaiche J, Louis E. Should patients under long-term anti-TNF therapies be followed 
for tuberculosis contamination? Inflamm Bowel Dis. 2010;16:1271-2.

60. Mankia S, Peters JE, Kang S, Moore S, Ehrenstein MR. Tuberculosis and anti-TNF treatment: experience of a central London hospital. Clin Rheumatol. 2011;30:399-401.

61. Jauregui-Amezaga A, Turon F, Ordás I, Gallego M, Feu F, Ricart E, Panés J. Risk of developing tuberculosis under anti-TNF treatment despite latent infection screening. J Crohns Colitis. 2013;7:208-12.

62. Bermejo F, Algaba A, Chaparro M, Taxonera C, Garrido E, García-Arata I, Guerra I, Gisbert JP, Olivares D, de-la-Poza G, López-Sanromán A. How frequently do tuberculosis screening tests convert in inflammatory bowel disease patients on anti-tumour necrosis factor-alpha? A pilot study. Dig Liver Dis. 2013;45:733-7.

63. Winthrop KL, Baxter R, Liu L, Varley CD, Curtis JR, Baddley JW, McFarland B, Austin D, Radcliffe L, Suhler E, Choi D, Rosenbaum JT, Herrinton LJ. Mycobacterial diseases and antitumour necrosis factor therapy in USA. Ann Rheum Dis. 2013;72:37-42.

64. Seminerio JL, Loftus EV Jr, Colombel JF, Thapa P, Sandborn WJ. Infliximab for Crohn's disease: the first 500 patients followed up through 2009. Dig Dis Sci. 2013;58:797-806.

65. Hsia EC, Schluger N, Cush JJ, Chaisson RE, Matteson EL, Xu S, Beutler A, Doyle MK, Hsu B, Rahman MU. Interferon- $\gamma$ release assay versus tuberculin skin test prior to treatment with golimumab, a human anti-tumor necrosis factor antibody, in patients with rheumatoid arthritis, psoriatic arthritis, or ankylosing spondylitis. Arthritis Rheum. 2012;64:2068-77.

66. Qumseya BJ, Ananthakrishnan AN, Skaros $\mathrm{S}$, Bonner M, Issa M, Zadvornova $\mathrm{Y}$, Naik A, Perera L, Binion DG. QuantiFERON TB gold testing for tuberculosis screening in an inflammatory bowel disease cohort in the United States. Inflamm Bowel Dis. 2011;17:77-83.

67. Campainha S, Gomes T, Carvalho A, Duarte R. Negative predictive value of TST and IGRA in anti-TNF treated patients. Eur Respir J. 2012;40:790-1.

68. Chen DY, Shen GH, Chen YM, Chen HH, Hsieh CW, Lan JL. Biphasic emergence of active tuberculosis in rheumatoid arthritis patients receiving TNF $\alpha$ inhibitors: the utility of IFN $\gamma$ assay. Ann Rheum Dis. 2012;71:231-7.

69. Raval A, Akhavan-Toyserkani G, Brinker A, Avigan M. Brief communication: characteristics of spontaneous cases of tuberculosis associated with infliximab. Ann Intern Med. 2007;147:699702.

70. Núñez Martínez O, Ripoll Noiseux C, Carneros Martín JA, González Lara V, Gregorio Marañón HG. Reactivation tuberculosis in a patient with anti-TNF-alpha treatment. Am J Gastroenterol. 2001;96:1665-6.

71. Arend SM, Leyten EM, Franken WP, Huisman EM, van Dissel JT. A patient with de novo tuberculosis during anti-tumor necrosis factoralpha therapy illustrating diagnostic pitfalls and paradoxical response to treatment. Clin Infect Dis. 2007;45:1470-5.

72. O'Dowd C, Kewin P, Morris J, Cotton M. Tuberculosis complicated by immune reconstitution inflammatory syndrome in a patient on anti-TNFa therapy for Crohn's disease. BMJ Case Rep. 2011;2011.

73. Carrión S, Domènech E, Romeu J. Pulmonary and nodal tuberculosis in a patient with inflammatory bowel disease and HIV infection treated with infliximab. J Crohns Colitis. 2009;3:220-1.

74. Rivoisy C, Amrouche L, Carcelain G, Séréni D, Bourgarit A. Paradoxical exacerbation of tuberculosis after TNF $\alpha$ antagonist discontinuation: beware of immune reconstitution inflammatory syndrome. Joint Bone Spine. 2011;78:312-5.

75. Caldera F, Grimes I, Soni A. Reactivation of latent tuberculosis in a Crohn's patient after TB prophylaxis treated with adalimumab. Am J Gastroenterol. 2013;108:1181-2.

76. Yoon YK, Kim JY, Sohn JW, Kim MJ, Koo JS, Choi JH, Park DW. Paradoxical response during antituberculous therapy in a patient discontinuing infliximab: a case report. J Med Case Rep. 2009;3:6673.

77. Milenković B, Dudvarski-Ilić A, Janković G, Martinović L, Mijac D. Anti-TNF treatment and miliary tuberculosis in Crohn's disease. Srp Arh Celok Lek. 2011;139:514-7.

78. Tissot C, Couraud S, Meng L, Girard P, Avrillon V, Gérinière L, Perrot E, Souquet PJ. Lifethreatening disseminated tuberculosis as a complication of treatment byinfliximab for Crohn's disease: report of two cases, including cerebral tuberculomas and miliary tuberculosis. J Crohns Colitis. 2012;6:946-9.

79. Martínez-Caselles A, Martínez-Pascual C, Muñoz-Tornero M, Sánchez-Torres A, CarballoÁlvarez F. Tuberculous monoarthritis after treatment with adalimumab in Crohn's disease. Rev Esp Enferm Dig. 2012;104:157-8.

80. Bonse-Geuking U, Kraus M. Primary tuberculous peritonitis during infliximab therapy 
for Crohn's disease. J Crohns Colitis. 2012;6:720-3.

81. Garcia-Vidal C, Rodríguez Fernández S, Martínez Lacasa J, Salavert M, Vidal R, Rodríguez Carballeira M, Garau J. Paradoxical response to antituberculous therapy in infliximab-treated patients with disseminated tuberculosis. Clin Infect Dis. 2005;40:756-9.

82. Colombel JF, Sandborn WJ, Reinisch W, Mantzaris GJ, Kornbluth A, Rachmilewitz D, Lichtiger S, D'Haens G, Diamond RH, Broussard DL, Tang KL, van der Woude $\mathrm{CJ}$, Rutgeerts P. Infliximab, azathioprine, or combination therapy for Crohn's disease. N Engl J Med. 2010;362:1383-95.

83. Swoger JM, Loftus EV Jr, Tremaine WJ, Faubion WA, Pardi DS, Kane SV, Hanson KA, Harmsen WS, Zinsmeister AR, Sandborn WJ. Adalimumab for Crohn's disease in clinical practice at Mayo clinic: the first 118 patients. Inflamm Bowel Dis. 2010;16:1912-21.

84. Winthrop KL, Chang E, Yamashita S, Iademarco MF, LoBue PA. Nontuberculous mycobacteria infections and anti-tumor necrosis factor-alpha therapy. Emerg Infect Dis. 2009;15:1556-61.

85. Levesque BG, Sandborn WJ. Mycobacterium marinum infection in the setting of antitumor necrosis factor alpha therapy for Crohn's disease. Inflamm Bowel Dis. 2011;17:1443-4.

86. Ferreira J, Grochowsky J, Krakower D, Zuromskis P, Baden R, Cheifetz AS. Mycobacterium marinum: an increasingly common opportunistic infection in patients on infliximab. Am J Gastroenterol. 2012;107:12689.

87. Kump PK, Högenauer C, Wenzl HH, Petritsch W. A case of opportunistic skin infection with Mycobacterium marinum during adalimumab treatment in a patient with Crohn's disease. J Crohns Colitis. 2013;7:e15-8.

88. Fallon JC, Patchett S, Gulmann C, Murphy GM. Mycobacterium marinum infection complicating Crohn's disease, treated with infliximab. Clin Exp Dermatol. 2008;33:43-5.

89. Ben Said B, Kanitakis J, Graber I, Berard F, Nicolas JF, Saurin JC, Augey F. Severe sporotrichoid fishtank granuloma following infliximab therapy for Crohn's disease. Inflamm Bowel Dis. 2010;16:375-6.

90. Ramos JM, García-Sepulcre MF, Rodríguez JC, Padilla S, Gutiérrez F. Mycobacterium marinum infection complicated by anti-tumour necrosis factor therapy. J Med Microbiol. 2010;59:61721.
91. Salvana EM, Cooper GS, Salata RA. Mycobacterium other than tuberculosis (MOTT) infection: an emerging disease ininfliximabtreated patients. J Infect. 2007;55:484-7.

92. Jordan N, Waghmare A, Abi-Ghanem AS, Moon A, Salvatore CM. Systemic Mycobacterium avium complex infection during antitumor necrosis factor- $\alpha$ therapy in pediatric Crohn disease. J Pediatr Gastroenterol Nutr. 2012;54:294-6.

93. Bodro M, Paterson DL. Listeriosis in patients receiving biologic therapies. Eur J Clin Microbiol Infect Dis. 2013;32:1225-30.

94. Morelli J, Wilson FA. Does administration of infliximab increase susceptibility to listeriosis? Am J Gastroenterol. 2000;95:841-2.

95. Tweezer-Zaks N, Shiloach E, Spivak A, Rapoport M, Novis B, Langevitz P. Listeria monocytogenes sepsis in patients treated with anti-tumor necrosis factor-alpha. Isr Med Assoc J. 2003;5:829-30.

96. de la Fuente Penco B, Marcó Piella A, Riera Mestre A, Boadas Mir J. Sepsis caused by Listeria monocytogenes related with the use of infliximab. Med Clin (Barc). 2005;124:398.

97. Williams G, Khan AA, Schweiger F. Listeria meningitis complicating infliximab treatment for Crohn's disease. Can J Infect Dis Med Microbiol. 2005;16:289-92.

98. Ramos JM, García-Sepulcre MF, Masiá M, Brotons A, Grau MC, Gutiérrez F. Listeria monocytogenes infection in patients with inflammatory bowel diseases receiving antitumor necrosis factor therapy. Rev Esp Enferm Dig. 2010;102:614-6.

99. Kamath BM, Mamula P, Baldassano RN, Markowitz JE. Listeria meningitis after treatment with infliximab. J Pediatr Gastroenterol Nutr. 2002;34:410-2.

100.Ramanampamonjy RM, Laharie D, Bonnefoy B, Vergniol J, Amouretti M. Infliximab therapy in Crohn's disease complicated by Listeria monocytogenes meningoencephalitis. Gastroenterol Clin Biol. 2006;30:157-8.

101.Gil C, Legido J, Cuenca C, Santamaría A, Sacristán MV, Salvatierra C, FernándezRubio E, Izquierdo J. Meningitis due to Listeria monocytogenes during adalimumab therapy. Gastroenterol Hepatol. 2009;32:587-8.

102. Chuang MH, Singh J, Ashouri N, Katz MH, Arrieta AC. Listeria meningitis after infliximab treatment of ulcerative colitis. $\mathrm{J}$ Pediatr Gastroenterol Nutr. 2010;50:337-9.

103.Abreu C, Magro F, Vilas-Boas F, Lopes S, Macedo G, Sarmento A. Listeria infection in patients on anti-TNF treatment: report of two 
cases and review of the literature. J Crohns Colitis. 2013;7:175-82.

104. Slifman NR, Gershon SK, Lee JH, Edwards ET, Braun MM. Listeria monocytogenes infection as a complication of treatment with tumor necrosis factor alpha-neutralizing agents. Arthritis Rheum.

105. Osuna Molina R, Ferrer Ríos T, Gallego Gallegos R, Ramos Lora M, Ynfante Ferrús M, Figueruela López B. Listeria meningitis as complication of treatment with infliximab in a patient with Crohn's disease. Rev Esp Enferm Dig. 2006;98:60-1.

106.Izbéki F, Nagy F, Szepes Z, Kiss I, Lonovics J, Molnár T. Severe Listeria meningoencephalitis in an infliximab-treated patient with Crohn's disease. Inflamm Bowel Dis. 2008;14:429-31.

107.Peña-Sagredo JL, Hernández MV, FernandezLlanio N, Giménez-Ubeda E, Muñoz-Fernandez $\mathrm{S}$, Ortiz A, Gonzalez-Gay MA, Fariñas MC. Listeria monocytogenes infection in patients with rheumatic diseases on TNF-alpha antagonist therapy: the Spanish Study Group experience. Clin Exp Rheumatol. 2008;26:854-9.

108.Davies R, Dixon WG, Watson KD, Lunt M, Symmons DP, Hyrich KL. Influence of anti-TNF patient warning regarding avoidance of high risk foods on rates of listeria and salmonella infections in the UK. Ann Rheum Dis. 2013;72:461-2.

109.Ljung T, Karlén P, Schmidt D, Hellström PM, Lapidus A, Janczewska I, Sjöqvist U, Löfberg R. Infliximab in inflammatory bowel disease: clinical outcome in a population based cohort from Stockholm County. Gut. 2004;53:849-53.

110.Lanternier F, Tubach F, Ravaud P, Salmon D, Dellamonica P, Bretagne S, Couret M, Bouvard B, Debandt M, Gueit I, Gendre JP, Leone J, Nicolas N, Che D, Mariette $\mathrm{X}$, Lortholary O. Incidence and Risk Factors of Legionella pneumophila Pneumonia During Anti-Tumor Necrosis Factor Therapy: A Prospective French Study. Chest. 2013;144:9908.

111. Tubach F, Ravaud P, Salmon-Céron D, Petitpain N, Brocq O, Grados F, Guillaume JC, Leport J, Roudaut A, Solau-Gervais E, Lemann M, Mariette X, Lortholary O. Emergence of Legionella pneumophila pneumonia in patients receiving tumor necrosis factor-alpha antagonists. Clin Infect Dis. 2006;43:e95-100.

112.Kohn A, Daperno M, Armuzzi A, Cappello M, Biancone L, Orlando A, Viscido A, Annese V, Riegler G, Meucci G, Marrollo M, Sostegni R, Gasbarrini A, Peralta S ,Prantera C.
Infliximab in severe ulcerative colitis: short-term results of different infusion regimens and longterm follow-up. Aliment Pharmacol Ther. 2007;26:747-56.

113. Beigel F, Jürgens M, Filik L, Bader L, Lück C, Göke B, Ochsenkühn T, Brand S, Seiderer J. Severe Legionella pneumophila pneumonia following infliximab therapy in a patient with Crohn's disease. Inflamm Bowel Dis. 2009;15:1240-4.

114.Hofmann A, Beaulieu Y, Bernard F, Rico P. Fulminant legionellosis in two patients treated with infliximab for Crohn's disease: case series and literature review. Can J Gastroenterol. 2009;23:829-33.

115.Epping G, van der Valk PD, Hendrix R. Legionella pneumophila pneumonia in a pregnant woman treated with anti-TNF- $\alpha$ antibodies for Crohn's disease: a case report. J Crohns Colitis. 2010;4:687-9.

116.Panaccione R, Loftus EV Jr, Binion D, McHugh K, Alam S, Chen N, Guerette B, Mulani P, Chao J. Efficacy and safety of adalimumab in Canadian patients with moderate to severe Crohn's disease: results of the Adalimumab in Canadian SubjeCts with ModErate to Severe Crohn's DiseaSe (ACCESS) trial. Can J Gastroenterol. 2011;25:419-25.

117.Herrlinger KR, Borutta A, Meinhardt G, Stange EF, Fellermann K. Fatal staphylococcal sepsis in Crohn's disease after infliximab. Inflamm Bowel Dis. 2004; 10:655-6.

118.Dhawan SS, Finks AL, Wang BW. Mycobacterial coxitis masked by concomitant staphylococcal infection after infliximab for Crohn's disease. Joint Bone Spine. 2009;76:1078.

119.Marques M, Rodrigues S, Mariz E, Pinto J, Videira T, Brito J, Reis C, Simões-Ventura F, Magro F. Severe gram positive bacterial infection in an ulcerative colitis patient treated with Infliximab. J Crohns Colitis. 2010;4:110-3.

120.Jin XH, Namba K, Saito W, Iwata D, Ishida S. Bacterial endophthalmitis caused by an intraocular cilium in a patient under treatment with infliximab. J Ophthalmic Inflamm Infect. 2013;3:50.

121.Togashi J, Sugawara Y, Akamatsu N, Aoki T, Ijichi M, Tanabe M, Kusaka K, Shibazaki M, Tadami T, Sakou M, Takazoe M, Bandai Y, Kokudo N. Resection of a methicillinresistant Staphylococcus aureus liver abscess in a patient with Crohn's disease under infliximab treatment: a case report. J Med Case Rep. 2013;7:36. 
122.Majumder S, Kumar A. Meningococcal meningoencephalitis after certolizumab pegol treatment in a patient with Crohn's disease. J Crohns Colitis. 2013;7:e19.

123. Singh SM, Rau NV, Cohen LB, Harris H. Cutaneous nocardiosis complicating management of Crohn's disease with infliximab and prednisone. CMAJ. 2004;171:1063-4.

124.Ali T, Chakraburtty A, Mahmood S, Bronze MS. Risk of nocardial infections with anti-tumor necrosis factor therapy. Am J Med Sci. 2013;346:166-8.

125.Parra MI, Martinez MC, Remacha MA, SaézNieto JA, Garcia E, Yagüe G, Guardiola J. Pneumonia due to Nocardia cyriacigeorgica in a patient with Crohn's disease treated with infliximab. J Crohns Colitis. 2008;2:331-2.

126. Saleemuddin A, Govender PP, Farraye FA. Nocardia pneumonia in a patient with Crohn's disease receiving 6-mercaptopurine and infliximab. J Crohns Colitis. 2013. In press. doi: 10.1016/j.crohns.2013.11.023.

127.Díez M, Sánchez E, García López S, Arroyo MT, Gomollón F. Infliximab therapy in ulcerative colitis: initial experience in two referral centers. Gastroenterol Hepatol. 2007;30:449-53.

128.Lees CW, Heys D, Ho GT et al. A retrospective analysis of the efficacy and safety of infliximab as rescue therapy in acute severe ulcerative colitis. Aliment Pharmacol Ther. 2007;26:411-9.

129.Rim JY, Tenorio AR. Salmonella septic arthritis in a patient with Crohn's disease on infliximab. Inflamm Bowel Dis. 2010;16:545-7.

130.Kukiolka T, Neurath MF, Mudter J. Abdominal pain due to cholecystitis as first sign of septic salmonellosis in a patient with Crohn's disease on infliximab. Inflamm Bowel Dis. 2011;17:E48-9.

131.Corberand D, Bredin C, Gizard E, Sava C, Rey P. Disseminated salmonella infection with aortic mycotic aneurysm in a ulcerative colitis patient treated with infliximab. Presse Med. 2013;42:1658-60.

132. Steinebrunner N, Sandig C, Zimmermann S, Stremmel W, Eisenbach C, Mischnik A. Salmonella enterica serovar Minnesota urosepsis in a patient with Crohn's disease in the absence of recent or current gastrointestinal symptoms. J Med Microbiol. 2013;62:1360-2.

133. Absah I, Faubion WA Jr. Concomitant therapy with methotrexate and anti-TNF- $\alpha$ in pediatric patients with refractory crohn's colitis: a case series. Inflamm Bowel Dis. 2012;18:1488-92.
134.Schneeweiss S, Korzenik J, Solomon DH, Canning C, Lee J, Bressler B. Infliximab and other immunomodulating drugs in patients with inflammatory bowel disease and the risk of serious bacterial infections. Aliment Pharmacol Ther. 2009;30:253-64.

135.Kaur N, Mahl TC. Pneumocystis jiroveci (carinii) pneumonia after infliximab therapy: a review of 84 cases. Dig Dis Sci. 2007;52:1481-4.

136. Wissmann G, Morilla R, Martín-Garrido I, Friaza V, Respaldiza N, Povedano J, PraenaFernández JM, Montes-Cano MA, Medrano FJ, Goldani LZ, de la Horra C, Varela JM, Calderón EJ. Pneumocystis jirovecii colonization in patients treated with infliximab. Eur J Clin Invest. 2011;41:343-8.

137. Minnee RC, Stokkers P, Riemens SC, Hommes DW. Pneumocystis pneumonia during infliximab treatment for active Crohn's colitis. Ned Tijdschr Geneeskd. 2005;149:2290-5.

138. Seddik M, Meliez H, Seguy D, Viget N, Cortot A, Colombel JF. Pneumocystis jiroveci (carinii) pneumonia following initiation of infliximab and azathioprine therapy in a patient with Crohn's disease. Inflamm Bowel Dis. 2004; 10:436-7.

139. Velayos FS, Sandborn WJ. Pneumocystis carinii pneumonia during maintenance anti-tumor necrosis factor-alpha therapy with infliximab for Crohn's disease. Inflamm Bowel Dis. 2004;10:657-60.

140.Stratakos G, Kalomenidis I, Papas V, Malagari K, Kollintza A, Roussos C, Anagnostopoulou M, Paniara O, Zakynthinos S, Papiris SA.. Cough and fever in a female with Crohn's disease receiving infliximab. Eur Respir J. 2005;26:354-7.

141.Itaba S, Iwasa T, Sadamoto Y, Nasu T, Misawa T, Inoue $\quad \mathrm{K}$, Shimokawa H, Nakamura K, Takayanagi R. Pneumocystis pneumonia during combined therapy of infliximab, corticosteroid, and azathioprine in a patient with Crohn's disease. Dig Dis Sci. 2007;52:1438-41.

142. Sharma K, Rao P, Krishnamurthy P, Ali SA, Beck G. Pneumocystis carinii jiroveci pneumonia following infliximab infusio $\mathrm{n}$ for Crohn disease: emphasis on prophylaxis. South Med J. 2007;100:331-2.

143. Estrada $\mathrm{S}$, García-Campos $\quad \mathrm{F}$, Calderón R, Delgado E, Bengoa R, Enciso C. Pneumocystis jiroveci

(carinii) pneumonia following a second infusion of infliximabin a patient with ulcerative colitis. Inflamm Bowel Dis. 2009;15:315-6. 
144.Desales AL, Mendez-Navarro J, Méndez-Tovar LJ, Ortiz-Olvera NX, Cullen G, Ocampo J, Lemus W, Tun AE, Mayoral-Zavala A, Dehesa-Violante M. Pneumocystosis in a patient with Crohn's disease treated with combination therapy with adalimumab. J Crohns Colitis. 2012;6:483-7.

145.Galandiuk S, Davis BR. Infliximab-induced disseminated histoplasmosis in a patient with Crohn's disease. Nat Clin Pract Gastroenterol Hepatol. 2008;5:283-7.

146.Tschudy J, Michail S. Disseminated histoplasmosis and pneumocystis pneumonia in a child with Crohn disease receiving infliximab. J Pediatr Gastroenterol Nutr. 2010;51:221-2.

147.Dotson JL, Crandall W, Mousa H, Honegger JR, Denson L, Samson C, Cunningham D, Balint J, Dienhart M, Jaggi P, Carvalho R. Presentation and outcome of histoplasmosis in pediatric inflammatory bowel disease patients treated with antitumor necrosis factor alpha therapy: a case series. Inflamm Bowel Dis. 2011;17:56-61.

148.Jain VV, Evans T, Peterson MW. Reactivation histoplasmosis after treatment with anti-tumor necrosis factor alpha in a patient from a nonendemic area. Respir Med. 2006;100:12913.

149.Abou Zahr A, Saad Aldin E, Yunyongying P. Histoplasma epiglottitis in a patient with Crohn's disease maintained on infliximab, prednisone, and azathioprine. Int J Infect Dis. 2013;17:e6502.

150.Warris A, Bjørneklett A, Gaustad P. Invasive pulmonary aspergillosis associated

with infliximab therapy. N Engl J Med. 2001;344:1099-100.

151.Manz M, Beglinger C, Vavricka SR. Fatal invasive pulmonary aspergillosis associated with adalimumab therapy. Gut. 2009;58:149.

152.Alderson JW, Van Dinter TG Jr, Opatowsky MJ, Burton EC. Disseminated aspergillosis following infliximab therapy in an immunosuppressed patient with Crohn's disease and chronic hepatitis $\mathrm{C}$ : a case study and review of the literature. MedGenMed. 2005;7:7.

153. Salavert M, Bastida G, Pemán J, Nos P. Opportunistic co-infection in a patient with Crohn's disease during infliximab (antiTNFalpha) therapy. Rev Iberoam Micol. 2009;26:213-7.

154.Rehman T, Ali J, Lopez FA. A 61-yearold man with asymptomatic, bilateral lung masse s. J La State Med Soc. 2008;160:309-14.

155.Hirai F, Matsui T, Ishibashi Y, Higashi D, Futami K, Haraoka S, Iwashita A.
Asymptomatic pulmonary cryptococcosis in a patient with Crohn's disease on infliximab: case report. Inflamm Bowel Dis. 2011;17:1637-8.

156. Takazono T, Izumikawa K, Yoshioka S, Matsuo N, Yamakawa M, Suyama N, Kohno S. Possible pulmonary cryptococcosis in a patient with Crohn's disease during anti-tumor necrosis factor-alpha treatment: a case report and literature review. Jpn J Infect Dis. 2012;65:4614.

157. Osawa R, Singh N. Colitis as a manifestation of infliximabassociated disseminated cryptococcosis. Int $\mathrm{J}$ Infect Dis. 2010;14:e436-40.

158.Fraison JB, Guilpain P, Schiffmann A, Veyrac M, Le Moing V, Rispail P, Le Quellec A. Pulmonary cryptococcosis in a patient with Crohn's disease treated with prednisone, azathioprine and adalimumab: exposure to chicken manure as a source of contamination. J Crohns Colitis. 2013;7:e11-4.

159. Belda A, Hinojosa J, Serra B, García L, Merino C, Belda A, Molés JR. Systemic candidiasis and infliximab therapy. Gastroenterol Hepatol. 2004;27:365-7.

160.Reinisch W, Sandborn WJ, Hommes DW, D'Haens G, Hanauer S, Schreiber S, Panaccione R, Fedorak RN, Tighe MB, Huang B, Kampman W, Lazar A, Thakkar R. Adalimumab for induction of clinical remission in moderately to severely active ulcerative colitis: results of a randomised controlled trial. Gut. 2011;60:780-7.

161.Cohen RD, Bowie WR, Enns R, Flint J, Fitzgerald JM. Pulmonary actinomycosis complicating inflixima b therapy for Crohn's disease. Thorax. 2007;62:1013-4.

162.McCann DA, Smith HL. Infliximabassociated Blastomycosis dermatitidis in treatment of ulcerative colitis. Colorectal Dis. 2013;15:e102-3.

163. Mitter SS, Derhovanessian A, Hillman JD, Uslan DZ. Disseminated coccidioidomycosis in a patient managed with adalimumab for Crohn's disease. Nat Rev Gastroenterol Hepatol. 2010;7:231-5.

164.Abramson A, Menter A, Perrillo R. Psoriasis, hepatitis B, and the tumor necrosis factor-alpha inhibitory agents: a review and recommendations for management. J Am Acad Dermatol. 2012;67:1349-61.

165.Centers for Disease Control and Prevention, Division of Viral Hepatitis. Interpretation of Hepatitis B Serologic Test Results. 2014. Accessed $\quad$ Feb $\quad 17 \quad 2014$. 
http://www.cdc.gov/hepatitis/hbv/pdfs/serologicc hartv8.pdf.

166.Park SH, Yang SK, Lim YS, Shim JH, Yang DH, Jung KW, Kim KJ, Ye BD, Byeon JS, Myung SJ, Kim JH. Clinical courses of chronic hepatitis B virus infection and inflammatory bowel disease in patients with both diseases. Inflamm Bowel Dis. 2012;18:2004-10.

167. Ueno Y, Tanaka S, Shimamoto M, Miyanaka Y, Hiyama T, Ito M, Kitadai Y, Yoshihara M, Sumii M, Chayama K. Infliximab therapy for Crohn's disease in a patient with chronic hepatitis B. Dig Dis Sci. 2005;50:163-6.

168. Ojiro K, Naganuma M, Ebinuma H, Kunimoto H, Tada S, Ogata H, Iwao Y, Saito H, Hibi T. Reactivation of hepatitis $\mathrm{B}$ in a patient with Crohn's disease treated using infliximab. J Gastroenterol. 2008;43:397-401.

169.Esteve M, Saro C, González-Huix F, Suarez F, Forné M, Viver JM. Chronic hepatitis B reactivation following infliximab therapy in Crohn's disease patients: need for primary prophylaxis. Gut. 2004;53:1363-5.

170.Colbert C, Chavarria A, Berkelhammer C. Fulminant hepatic failure in chronic hepatitis B on withdrawal of corticosteroids, azathioprine and infliximab for Crohn's disease. Inflamm Bowel Dis. 2007;13:1453-4.

171.Millonig G, Kern M, Ludwiczek O, Nachbaur K, Vogel W. Subfulminant hepatitis B after infliximab in Crohn's disease: need for HBVscreening? World J Gastroenterol. 2006;12:9746.

172.Pérez-Alvarez R, Díaz-Lagares C, GarcíaHernández F, Lopez-Roses L, Brito-Zerón P, Pérez-de-Lis M, Retamozo S, Bové A, Bosch $\mathrm{X}$, Sanchez-Tapias JM,Forns X, Ramos-Casals $M$ Hepatitis $B$ virus (HBV) reactivation in patients receiving tumor necrosis factor (TNF)targeted therapy: analysis of 257 cases. Medicine (Baltimore). 2011;90:359-71.

173.Garcia-Vidal C, Rodríguez-Fernández S, Teijón S, Esteve M, Rodríguez-Carballeira M, Lacasa JM, Salvador G, Garau J. Risk factors for opportunistic infections in infliximab-treated patients: the importance of screening in prevention. Eur J Clin Microbiol Infect Dis. 2009;28:331-7.

174. Madonia S, Orlando A, Scimeca D, Olivo M, Rossi F, Cottone M. Occult hepatitis B and infliximab-induced HBV reactivation. Inflamm Bowel Dis. 2007;13:508-9.

175.del Valle García-Sánchez M, Gómez-Camacho F, Poyato-González A, Iglesias-Flores EM, de Dios-Vega JF, Sancho-Zapatero R. Infliximab therapy in a patient with Crohn's disease and chronic hepatitis $\mathrm{B}$ virus infection. Inflamm Bowel Dis. 2004;10:701-2.

176.Caporali R, Bobbio-Pallavicini F, Atzeni F, Sakellariou G, Caprioli M, Montecucco C, Sarzi-Puttini P. Safety of tumor necrosis factor alpha blockers in hepatitis B virus occult carriers (hepatitis B surface antigen negative/anti-hepatitis $\mathrm{B}$ core antigen positive) with rheumatic diseases. Arthritis Care Res (Hoboken). 2010;62:749-54.

177. Vassilopoulos D, Apostolopoulou A, Hadziyannis E, Papatheodoridis GV, Manolakopoulos S, Koskinas J, Manesis EK, Archimandritis AI. Long-term safety of antiTNF treatment in patients with rheumatic diseases and chronic or resolved hepatitis B virus infection. Ann Rheum Dis. 2010;69:1352-5.

178. Moses J, Alkhouri N, Shannon A, Raig K, Lopez $\mathrm{R}$, Danziger-Isakov L, Feldstein AE, Zein NN, Wyllie R, Carter-Kent C. Hepatitis $\mathrm{B}$ immunity and response to booster vaccination in children with inflammatory bowel disease treated with infliximab. Am J Gastroenterol. 2012;107:133-8.

179. Neuman MG, Benhamou JP, Malkiewicz IM, Akremi R, Shear NH, Asselah T, Ibrahim A, Boyer N, Martinot-Peignoux M, JacobsonBrown P, Katz GG, Le Breton V, Le Guludec G, Suneja A, Marcellin P. Cytokines as predictors for sustained response and as markers for immunomodulation in patients with chronic hepatitis C. Clin Biochem. 2001;34:173-82.

180.Neuman MG, Blendis LM, Shear NH, Malkiewicz IM, Ibrahim A, Katz GG, Sapir D, Halpern Z, Brill S, Peretz H, Magazinik S, Konikoff FM. Cytokine network in nonresponding chronic hepatitis $\mathrm{C}$ patients with genotype 1: role of triple therapy with interferon alpha, ribavirin, and ursodeoxycholate. Clin Biochem. 2001;34:183-8.

181.Neuman MG, Benhamou JP, Malkiewicz IM, Ibrahim A, Valla DC, Martinot-Peignoux M, Asselah T, Bourliere M, Katz GG, Shear NH, Marcellin P. Kinetics of serum cytokines reflect changes in the severity of chronic hepatitis $\mathrm{C}$ presenting minimal fibrosis. J Viral Hepat. 2002;9:134-40.

182.Neuman MG, Benhamou JP, Ibrahim A, Malkiewicz I, Spircu T, Martinot-Peignoux M, Shear NH, Katz GG, Akremi R, Bourliere M, Marcellin P. Role of cytokines in the assessment of the severity of chronic hepatitis $\mathrm{C}$ and the prediction of response to therapy. Rom $\mathrm{J}$ Gastroenterol. 2002;11:97-103.

183. Neuman MG, Benhamou JP, Marcellin P, Valla D, Malkiewicz IM, Katz GG, Trepo C, Bourliere 
M, Cameron RG, Cohen L, Morgan M, Schmilovitz-Weiss H, Ben-Ari Z. Cytokine-chemokine and apoptotic signatures in patients with hepatitis C. Transl Res. 2007;149:126-36.

184. Neuman MG, Schmilovitz-Weiss H, Hilzenrat $\mathrm{N}$, Bourliere M, Marcellin P, Trepo C, Mazulli T, Moussa G, Patel A, Baig AA, Cohen L. Markers of inflammation and fibrosis in alcoholic hepatitis and viral hepatitis C. Int $\mathrm{J}$ Hepatol. 2012;2012:231210.

185. Brunasso AM, Puntoni M, Gulia A, Massone C. Safety of anti-tumour necrosis factor agents in patients with chronic hepatitis $\mathrm{C}$ infection: a systematic review. Rheumatology (Oxford). 2011;50:1700-11.

186.Campbell S, Ghosh S. Infliximab therapy for Crohn's disease in the presence of chronic hepatitis C infection. Eur J Gastroenterol Hepatol. 2001;13:191-2.

187.Holtmann MH, Galle PR, Neurath MF. Treatment of patients with Crohn's disease and concomitant chronic hepatitis $\mathrm{C}$ with a chimeric monoclonal antibody to TNF. Am J Gastroenterol. 2003;98:504-5.

188. Abdelmalek MF, Liu C, Valentine JF. Successful treatment of chronic hepatitis $\mathrm{C}$ with pegylated interferon, ribavirin, and infliximab in a patient with Crohn's disease. Am J Gastroenterol. 2007;102:1333-4.

189.Papa A, Felice C, Marzo M, Andrisani G, Armuzzi A, Covino M, Mocci G, Pugliese D, De Vitis I, Gasbarrini A, Rapaccini GL, Guidi L. Prevalence and natural history of hepatitis $B$ and $\mathrm{C}$ infections in a large population of IBD patients treated with anti-tumor necrosis factor- $\alpha$ agents. J Crohns Colitis. 2013;7:113-9.

190.Katsanos KH, Tsianos VE, Zois CD, Zioga $\mathrm{H}$, Vagias I, Zervou E, Christodoulou DK, Tsianos EV. Inflammatory bowel disease and hepatitis $\mathrm{B}$ and $\mathrm{C}$ in Western Balkans: a referral centre study and review of the literature. J Crohns Colitis. 2010;4:450-65.

191.Lin MV, Blonski W, Buchner AM, Reddy KR, Lichtenstein GR. The influence of anti-TNF therapy on the course of chronic hepatitis $\mathrm{C}$ virus infection in patients with inflammatory bowel disease. Dig Dis Sci. 2013;58:1149-56.

192.Uda H, Kuhara M, Nishimoto N, Saiki O. Progression of viraemia during treatment with infliximab in a patient with rheumatoid arthritis and chronic hepatitis $\mathrm{C}$ infection. BMJ Case Rep. 2009;2009.

193.Cooper C, Shafran S, Greenbloom S, Enns R, Farley J, Hilzenrat N, Williams K, Elkashab M, Abadir N, Neuman M. Single-dose infliximab in hepatitis $\mathrm{C}$ genotype 1 treatment-naive patients with high serum tumour necrosis factoralpha does not influence the efficacy of pegylated interferon alpha-2b/ribavirin therapy. Can J Gastroenterol. 2014;28:35-40.

194.Beltrán B, Nos P, Bastida G, Iborra M, Hoyos M, Ponce J. Safe and effective application of anti-TNF-alpha in a patient infected with HIV and concomitant Crohn's disease. Gut. 2006;55:1670-1.

195. Sellam J, Bouvard B, Masson C, Rousière M, Villoutreix C, Lacombe K, Khanine V, Chennebault JM, Leclech C, Audran $\mathrm{M}$, Berenbaum $\mathrm{F}$. Use of infliximab to treat psoriatic arthritis in HIV-positive patients. Joint Bone Spine. 2007;74:197-200.

196.Cepeda EJ, Williams FM, Ishimori ML, Weisman MH, Reveille JD. The use of antitumour necrosis factor therapy in HIV-positive individuals with rheumatic disease. Ann Rheum Dis. 2008;67:710-2.

197.Habib SF, Hasan MZ, Salam I. Infliximab therapy for HIV positive Crohn's disease: A case report. J Crohns Colitis. 2009;3:302-4.

198.Filippi J, Roger PM, Schneider SM, Durant J, Breittmayer JP, Benzaken S, Bernard A, Dellamonica P, Hébuterne X. Infliximab and human immunodeficiency virus infection: Viral load reduction and CD4+ T-cell loss related to apoptosis. Arch Intern Med. 2006;166:1783-4.

199. Gaylis NB. Long-term follow-up of an HIVinfected patient with reactive arthritis treated with infliximab. J Clin Rheumatol. 2012;18:1534.

200.Shale MJ, Seow CH, Coffin CS, Kaplan GG, Panaccione R, Ghosh S. Review article: chronic viral infection in the anti-tumour necrosis factor therapy era in inflammatory bowel disease. Aliment Pharmacol Ther. 2010;31:20-34.

201.Lavagna A, Bergallo M, Daperno M, Sostegni $\mathrm{R}$, Costa C, Leto R, Crocellà L, Molinaro G, Rocca R, Cavallo R, Pera A. Infliximab and the risk of latent viruses reactivation in active Crohn's disease. Inflamm Bowel Dis. 2007;13:896-902.

202.Comar M, Delbue S, Lepore L, Martelossi S, Radillo O, Ronfani L, D'Agaro P, Ferrante P. Latent viral infections in young patients with inflammatory diseases treated with biological agents: prevalence of JC virus genotype 2. J Med Virol. 2013;85:716-22.

203. Nakase H, Matsumura K, Yoshino T, Chiba T. Systematic review: cytomegalovirus infection in inflammatory bowel disease. J Gastroenterol. 2008;43:735-40. 
204. Yoshino T, Nakase H, Ueno S, Uza N, Inoue S, Mikami S, Matsuura M, Ohmori K, Sakurai T, Nagayama S, Hasegawa S, Sakai Y, Chiba T. Usefulness of quantitative real-time PCR assay for early detection of cytomegalovirus infection in patients with ulcerative colitis refractory to immunosuppressive therapies. Inflamm Bowel Dis. 2007; 13:1516-21.

205.Hommes DW, Sterringa G, van Deventer SJ, Tytgat GN, Weel J. The pathogenicity of cytomegalovirus in inflammatory bowel disease: a systematic review and evidence-based recommendations for future research. Inflamm Bowel Dis. 2004;10:245-50.

206. Nakase H, Chiba T. TNF-alpha is an important pathogenic factor contributing to reactivation of cytomegalovirus in inflamed mucosa of colon in patients with ulcerative colitis: lesson from clinical experience. Inflamm Bowel Dis. 2010;16:550-1.

207.Helbling D, Breitbach TH, Krause M. Disseminated cytomegalovirus infection in Crohn's disease following anti-tumour necrosis factor therapy. Eur J Gastroenterol Hepatol. 2002;14:1393-5.

208.Kohara MM, Blum RN. Cytomegalovirus ileitis and hemophagocytic syndrome associated with use of anti-tumor necrosis factor-alpha antibody. Clin Infect Dis. 2006;42:733-4.

209.Pickering O, Weinstein T, Rubin LG. Fatal disseminated cytomegalovirus infection associated with infliximab and 6-mercaptopurine therapy in a child with Crohn disease. Pediatr Infect Dis J. 2009;28:556.

210.Mizuta M, Schuster MG. Cytomegalovirus hepatitis associated with use of anti-tumor necrosis factor-alpha antibody. Clin Infect Dis. 2005;40:1071-2.

211.Grinde B. Herpesviruses: latency and reactivation - viral strategies and host response. J Oral Microbiol. 2013. In press. doi: 10.3402/jom.v5i0.22766.

212.Leung VS, Nguyen MT, Bush TM. Disseminated primary varicella after initiation of infliximab for Crohn's disease. Am J Gastroenterol. 2004;99:2503-4.

213.Kunz AN, Rajnik M. Disseminated cutaneous varicella $\quad$ zoster virus infections during infliximab therapy for Crohn's disease: case report of two pediatric patients at one institution. Clin Pediatr (Phila). 2011;50:559-61.

214.Nobile S, Catassi C, Felici L. Herpes zoster infection followed by Henoch-Schönlein purpura in a girl receiving infliximab for ulcerative colitis. $\quad J \quad$ Clin Rheumatol. 2009;15:101.
215.Cruz MJ, Baudrier T, Ferreira O, Azevedo F. Herp zoster at the site of infliximab infusion: case report. Cutan Ocul Toxicol. 2011;30:236-8.

216.Failla V, Jacques J, Castronovo C, Nikkels AF. Herpes zoster in patients treated with biologicals. Dermatology. 2012;224:251-6.

217.Ma C, Walters B, Fedorak RN. Varicella zoster meningitis complicating combined antitumor necrosis factor and corticosteroid therapy in Crohn's disease. World J Gastroenterol. 2013;19:3347-51.

218. Wang X, Zhao J, Zhu S, Xia B. Herpes zoster in Crohn's disease during treatment with infliximab. Eur J Gastroenterol Hepatol. 2014;26:237-9.

219. Colombel JF, Loftus EV Jr, Tremaine WJ, Egan LJ, Harmsen WS, Schleck CD, Zinsmeister AR, Sandborn WJ. The safety profile of infliximab in patients with Crohn's disease: the Mayo clinic experience in 500 patients. Gastroenterology. 2004;126:19-31.

220.Serac G, Tubach F, Mariette X, Salmon-Céron D, Ravaud P, Lioté F, Laharie D, Ziza JM, Marguerie L, Bonnet C, Falgarone G, Nicolas N, Lortholary O, Chosidow O. Risk of herpes zoster in patients receiving anti-TNF- $\alpha$ in the prospective French RATIO registry. J Invest Dermatol. 2012;132:726-9.

221.Sprakes MB, Hamlin PJ, Warren L, Greer D, Ford AC. Adalimumab as second line antitumour necrosis factor alpha therapy for Crohn'sdisease: A single centre experience. J Crohns Colitis. 2011;5:324-31.

222. Checchin D, Buda A, Sgarabotto D, Sturniolo GC, D' Incà R. Successful prophylaxis with valaciclovir for relapsing HSV-1 in a girl treated with infliximab for moderate Crohn's disease. Eur J Gastroenterol Hepatol. 2009;21:1095-6.

223. Magro F, Santos-Antunes J, Albuquerque A, Vilas-Boas F, Macedo GN, Nazareth N, Lopes S, Sobrinho-Simões J, Teixeira S, Dias CC, Cabral J, Sarmento A, Macedo G. EpsteinBarr virus in inflammatory bowel diseasecorrelation with different therapeutic regimens. Inflamm Bowel Dis. 2013;19:1710-6.

224.Al Jawhari M, Mardivirin L, Sautereau D, Ranger-Rogez S. HHV-6 is present at the gut level and may be implicated in certain diseases. Poster presented at the 8th International Conference on HHV-6 \& 7, 2013, Paris, France.

225. Yao K, Gagnon S, Akhyani N, Williams E, Fotheringham J, Frohman E, Stuve O, Monson N, Racke MK, Jacobson S. Reactivation of human herpesvirus-6 in natalizumab treated multiple sclerosis patients. PLoS One. 2008;3:e2028. 
226.Bellizzi A, Anzivino E, Ferrari F, Di Nardo G, Colosimo MT, Fioriti D, Mischitelli M, Chiarini F, Cucchiara S, Pietropaolo V. Polyomavirus JC reactivation and noncoding control region sequence analysis in pediatric Crohn's disease patients treated with infliximab. J Neurovirol. 2011;17:303-13.

227. Giannecchini S, Clausi V, Vultaggio A, Macera L, Maggi F, Martelli F, Azzi A, Maggi E, Matucci A. Assessment of the risk of polyomavirus JC reactivation in patients with immune-mediated diseases during long-term treatment with infliximab.

Neurovirol. 2012;18:55-61.

228. Mamula P, Markowitz JE, Piccoli DA, Klimov A, Cohen L, Baldassano RN. Immune response to influenza vaccine in pediatric patients with inflammatory bowel disease. Clin Gastroenterol Hepatol. 2007;5:851-6.

229.Kobie JJ, Zheng B, Bryk P, Barnes M, Ritchlin CT, Tabechian DA, Anandarajah AP, Looney RJ, Thiele RG, Anolik JH,Coca A, Wei C, Rosenberg AF, Feng C, Treanor JJ, Lee FE, Sanz I. Decreased influenza-specific B cell responses in rheumatoid arthritis patients treated with anti-tumor necrosis factor. Arthritis Res Ther. 2011;13:R209.

230.Gelinck LB, van der Bijl AE, Beyer WE, Visser LG, Huizinga TW, van Hogezand RA, Rimmelzwaan GF, Kroon FP. The effect of anti-tumour necrosis factor alpha treatment on the antibody response to influenza vaccination. Ann Rheum Dis. 2008;67:713-6.

231.Pillot C, Chevaux JB, Petitpain N, PeyrinBiroulet L. Acute hepatic cytolysis following H1N1 vaccination in a patient with Crohn's disease on infliximab. Inflamm Bowel Dis. 2011;17:679.

232. Yousry TA, Major EO, Ryschkewitsch C, Fahle G, Fischer S, Hou J, Curfman B, Miszkiel K, Mueller-Lenke N, Sanchez E, Barkhof F, Radue EW, Jäger HR, Clifford DB. Evaluation of patients treated with natalizumab for progressive multifocal leukoencephalopathy. N Engl J Med. 2006;354:924-33.

233.Ransohoff RM. Natalizumab for multiple sclerosis. N Engl J Med. 2007;356:2622-9.

234. Singh S, Kumar N, Loftus EV Jr, Kane SV. Neurologic complications in patients with inflammatory bowel disease: increasing relevance in the era of biologics. Inflamm Bowel Dis. 2013;19:864-72.

235. Gorelik L, Lerner M, Bixler S, Crossman M, Schlain B, Simon K, Pace A, Cheung A, Chen LL, Berman M, Zein F, Wilson E, Yednock T, Sandrock A, Goelz SE, Subramanyam M. Anti-
JC virus antibodies: implications for PML risk stratification. Ann Neurol. 2010;68:295-303.

236. Sandborn W, Colombel JF, Enns R, Feagan BG, Hanauer SB, Lawrance IC, Panaccione R, Sanders M, Schreiber S, Targan S, van Deventer S, Goldblum R, Despain D, Hogge GS, Rutgeerts P. Natalizumab induction and maintenance therapy for Crohn's disease. N Engl J Med. 2005;353:1912-25.

237. Targan SR, Feagan BG, Fedorak RN, Lashner BA, Panaccione R, Present DH, Spehlmann ME, Rutgeerts PJ, Tulassay Z, Volfova M, Wolf DC, Hernandez C,Bornstein J, Sandborn WJ. Natalizumab for the treatment of active Crohn's disease: results of the ENCORE Trial. Gastroenterology. 2007;132:1672-83.

238. Chen CH, Kularatna G, Stone CD, Gutierrez AM, Dassopoulos T. Clinical experience of natalizumab in Crohn's disease patients in a restricted distribution program. Ann Gastroenterol. 2013;26:189-190.

239. Sakuraba A, Keyashian K, Correia C, Melek J, Cohen RD, Hanauer SB, Rubin DT. Natalizumab in Crohn's disease: results from a US tertiary inflammatory bowel disease center. Inflamm Bowel Dis. 2013;19:621-6.

240.Sandborn WJ, Feagan BG, Rutgeerts P, Hanauer $\mathrm{S}$, Colombel JF, Sands BE, Lukas M, Fedorak RN, Lee S, Bressler B, Fox I, Rosario M, Sankoh $\mathrm{S}, \mathrm{Xu}$ J,Stephens K, Milch C, Parikh A. Vedolizumab as induction and maintenance therapy for Crohn's disease. N Engl J Med. 2013;369:711-21.

241.Feagan BG, Rutgeerts P, Sands BE, Hanauer S, Colombel JF, Sandborn WJ, Van Assche G, Axler J, Kim HJ, Danese S, Fox I, Milch C, Sankoh S, Wyant T, Xu J, Parikh A. Vedolizumab as induction and maintenance therapy for ulcerative colitis. N Engl $\mathrm{J}$ Med. 2013;369:699-710.

242. Sands BE, Feagan BG, Rutgeerts P, Colombel JF, Sandborn WJ, Sy R, D'Haens G, Ben-Horin $\mathrm{S}$, Xu J, Rosario M, Fox I, Parikh A, Milch C, Hanauer S. Effects of Vedolizumab Induction Therapy for Patients With Crohn's Disease in Whom Tumor Necrosis Factor Antagonist Treatment Had Failed. Gastroenterology. 2014. In press. doi: 10.1053/j.gastro.2014.05.008.

243. Oshitani N, Watanabe K, Maeda K, Fujiwara Y, Higuchi $\quad \mathrm{K}$, Matsumoto $\mathrm{T}$, Arakawa $\mathrm{T}$. Differential expression of homing receptor CD103 on lamina propria lymphocytes and association of CD103 with epithelial adhesion molecules in inflammatory bowel disease. Int $\mathbf{J}$ Mol Med. 2003;12:715-9. 
244.Lobatón T, Vermeire S, Van Assche G, Rutgeerts P. Review article: anti-adhesion therapies for inflammatory bowel disease. Aliment Pharmacol Ther. 2014;39:579-94.

245. Vermeire S, O'Byrne S, Keir M, Williams M, Lu TT, Mansfield JC, Lamb CA, Feagan BG, Panes J, Salas A, Baumgart DC, Schreiber S, Dotan I, Sandborn WJ, Tew GW, Luca D, Tang MT, Diehl L, Eastham-Anderson J, De Hertogh G, Perrier C, Egen JG, Kirby JA, van Assche G, Rutgeerts P. Etrolizumab as induction therapy for ulcerative colitis: a randomised, controlled, phase 2 trial. Lancet. 2014;384:309-18.

246. Rutgeerts PJ, Fedorak RN, Hommes DW, Sturm A, Baumgart DC, Bressler B, Schreiber S, Mansfield JC, Williams M, Tang M, Visich J, Wei X, Keir M, Luca D,Danilenko D, Egen J, O'Byrne S. A randomised phase I study of etrolizumab (rhuMAb $\beta 7$ ) in moderate to severe ulcerative colitis. Gut. 2013;62:1122-30.

247. Ordás I, Feagan BG, Sandborn WJ. Therapeutic drug monitoring of tumor necrosis factor antagonists in inflammatory bowel disease. Clin Gastroenterol Hepatology. 2012;10:1079-87. 